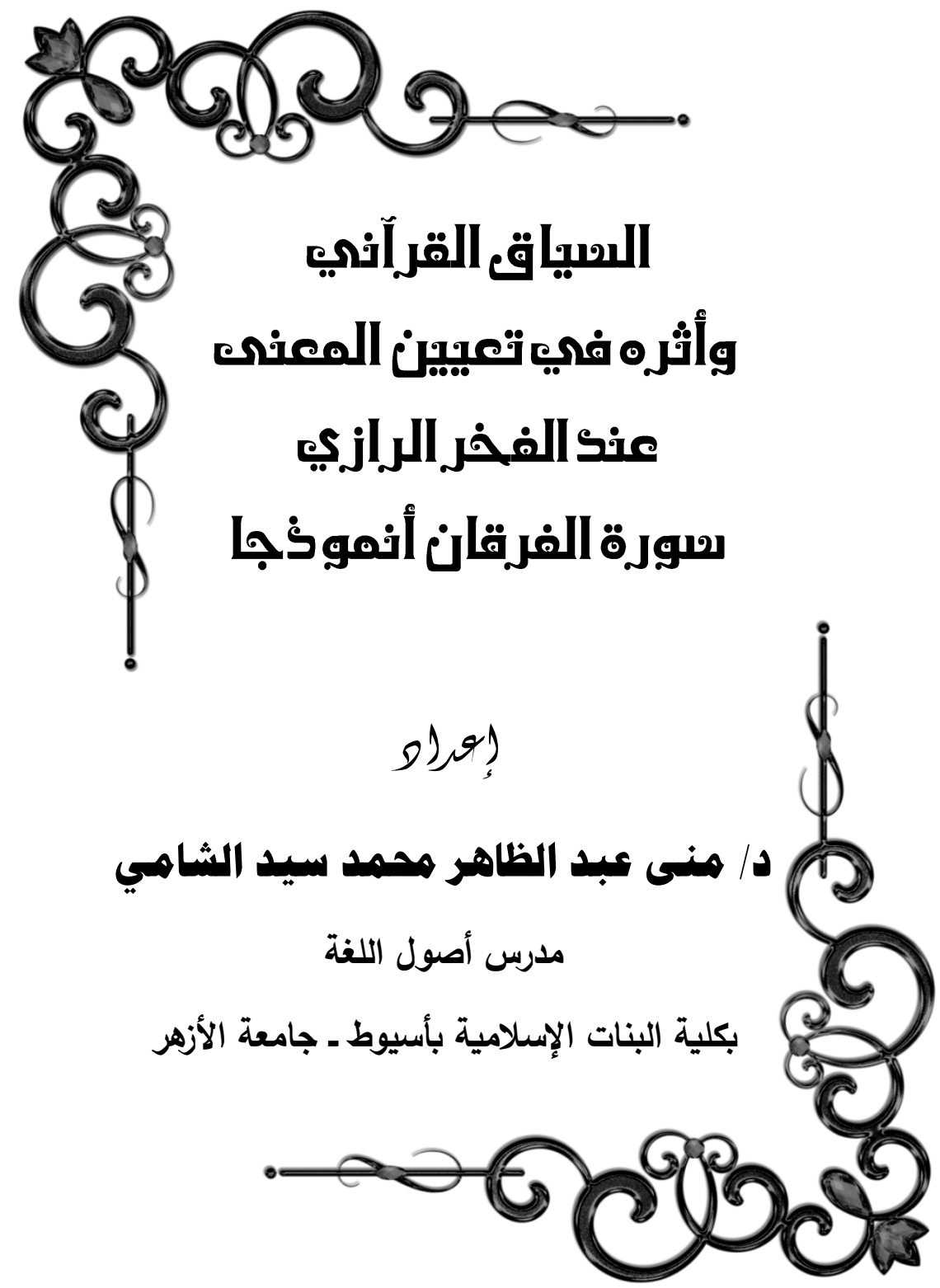




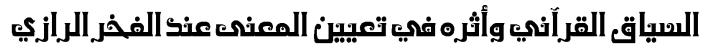

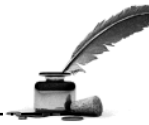


مجلة قطاع كليات اللفة العريية والثعب المناظرة لها العكى [ثا]

\section{هلفص البمث}

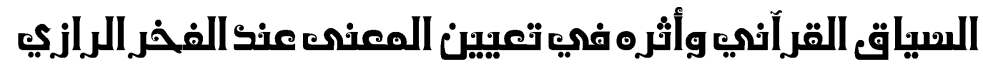

\section{لسورة الفررقان أنموذَجا}

$$
\text { إعداد }
$$

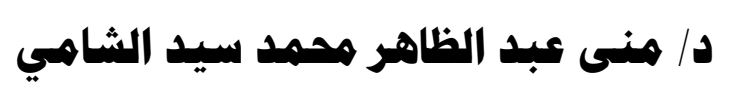

إن نظريـة السياق من النظريـات الدلالية متعددة الفوائد في ميدان البحث

اللغوي؛ ولا سيما فيما يتعلق باستجلاء المعاني من النصوص، ومن أبرز هذه الفوائد تعيين المحتمل من المعاني في الموضـع الواحد، وبمـا أن كتب لتب التفسير تعد من أخصب المؤلفات التي ظهرت فيها كثرة المحتملات في معنى الآيـة القرآنية الواحدة، فيترتب عليه غموض بعض الدلالات؛ فعقدت العزم على إبراز دور نظرية السياق في تعيين المعنى، وإزالة الغموض عنه، من خلال تطبيق أسس التحليل السياقي على المحتملات الواردة في معاني بعض آيات سورة الفرقان في تفسير الإمام الفخر الرازي. 


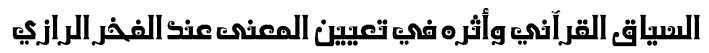

Summary

The Qur'anic context and its effect on defining meaning when al-Razi's pride Sura al-Furqan model

Set up

\section{Dr. Mona Abdul Zahir Mohammed Sayed al-Shami}

The theory of the context of the semantic theories of multiple benefits in the field of linguistic research, especially with regard to the clarification of meanings of the texts, the most prominent of these benefits of the possible identification of the meanings in one place, and since the books of interpretation is one of the most fertile works in which there appeared many potential in the meaning of the verse He determined to highlight the role of context theory in defining meaning and demystifying it by applying the fundamentals of contextual analysis to the potentials contained in the meanings of some of the verses of Surat al-Furqan in the interpretation of Imam al-Fakhr al-Razi. 


\section{المقدهة}

الحمد الله منزل الفرقان؛ ليهدي لنور الإيمان بني آدم، والصلاة والسلام على

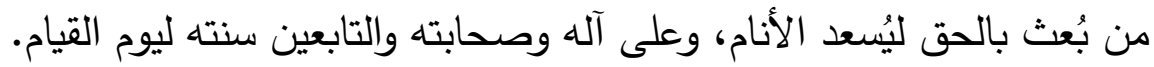

\section{وبعد،}

فنظرية السياق من النظريات القديمة الحديثة التي تناولها العلماء قديمًا ضمن الحديث عن النظم ومن أشهر هؤلاء عبد القاهر الجرجاني، وإن كان إنان

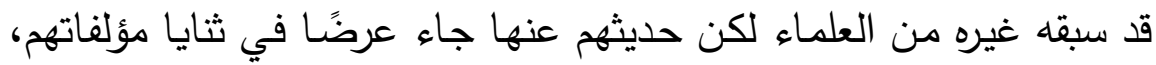
وجاء المحدثون فبينوها وأفردوا لها مؤلفات للحديث عن أنواعها وتقسيماتها فياه

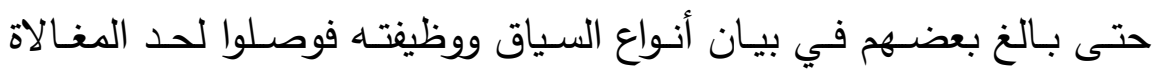
والاضطراب عند البعض، ولكن ذلك لا يبخسها قيمتها العظمى في فهم

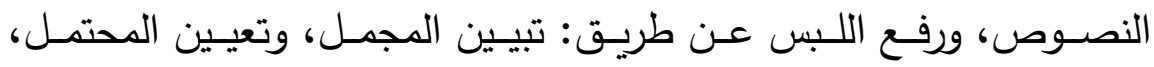
وتخصيص العام، وتتييد المطلق وغير ذلك من فوائد السياق التي ذكرها لنا ابن القيم في حديثه عن فائدة السياق، فيقول فيه: 》السياق يرشد إلى تبيين المجمل وتعيين المحتمل والقطع بعدم احتمال غير المراد وتخصيص العام

وتقييد المطلق وتتوع الدلالة.ه (1)

فاعتمــ المفسـرون والثــراح على السـياق لإزالـة غــوض النصــوص

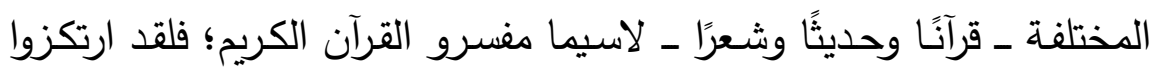
بشكل واضح في تفسيره على هذه النظرية، لما للسياق من مقدرة على تحديد

(') (') بدائع الفو ائد، محمد بن أبي بكر بن أيوب بن سعد شمس الدين ابن قيم الجوزية، ( ( ( ) دار الكتاب العربي، بيروت، لبنان. 
المعنى المـراد خاصــة الألفـاظ المتقاربــة معنىى أو المتحـدة لفظًا، ولا سـيما الآيات المتثـابهة، والقصص المتكررة فيها، والتي تتطلب لفهم المراد منها الإلمام بالسياق الداخلي والخارجي لها، فكم من دلالات قرآنية عميت بسبب الفهم الخاطئ للسياق، ومن تلك الدلالات التي تؤدي للتخبط في فهم القرآن الكـريم، كثرة المحتملات مسن الـدلالات القرآنيـة في الموضـع الواحد فهي القضايا التي اكتظت بها كتب المفسرين في أثناء تفسير الآيات والألفاظ، ما خلق بداخلي سؤالًا حول مدى إمكانية تعيين المحتمل في التقسيرات القرآنية بمعونة السياق، ولإجابة عن هذا السؤال عقدت العزم على النظر في كتب التفسير ـ مستعينة باله ـ للبحث عن أكثرها عناية بذكر محتملات المعنى؛ فوجدت أن تغسير مفاتيح الغيب للإمام الرازي، ممتلئ بالدلالات المحتملة في بلي تفسير الآيات، ولا سيما سورة الفرقان؛ فلقد جاء في أثناء تفسيرها بالعديد من المـواطن التي ذكـر المفسـرون فيهـا تـأويلات محتملـة للمعـاني الـواردة في الآيـات الكريمـة، وفي هذا السـياق تأتي هذه الدراسـة، وعنوانهـا: (السـياق القرآني وأثره في تعيين المعنى عند الفخر الرازي سورة الفرقان أنموذجًا) ولقد استندت إلى المنهج الوصفي المعتمد على إجراءات التحليل في هذه الدراسة، وذلك بذكر الآيات التي تتضمن المعاني التفسيرية المحتملة؛ والبحث بمعونـة السـياقات الداخليـة والخارجيـة، عـن المعنى الذي يناسـب السـياق، بــكر مرشحات لله سواء أكانت مرشحات مقالية أم مقامية.

\section{وتطمح هذه الاراسة لتحقيق بعض الأهداف، ومنها:}

بيـان قيمـة التحليـل السياقي في ترجيح مـا اختلف فيـه في تفسير النص القرآني. 
إبراز القيمـة التي تمتع بها تفسير الإمـام الرازي بـين التفاسير التي عنيت بجمع الآراء التفسيرية المختلفة، وتوضيح رأيه فيها. إعادة القراءة التفسيرية لسورة الفرقان، بعين النظريـة السياقية، لإخراجها في صورة أوضح وأيسر للقارئ، فيعمل عقله وفكره ليقبل على الخالق ـ عز وجل - 2 - مكل طواعية ومحبة.

وتقوم هذه الدراسـة على مسـتوين متـرابطين هــا: المسـتوى النظـري والمسـتوى التطبيقسي، فـاحتوت بـذلك على سـتة مطالب، يسـبقها المقدمـة والتمهيد وتتلوها الخاتمة. فالمقدمسـة تتاولـت فيهـا ماهيـة الموضـوع، وأسـباب اختيـاره، وخطتهـ، والمنهج الذي اعتمدت عليه في الدراسة، ومصادره. وأما التمهيد: وعنوانه (السياقية والفرقان قراءة نظرية تفسيرية) وهو تمهيد

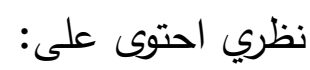
أولًا: تحرير لمصطلح السياق ـ وهو المحور الرئيس هنا ـ فذكرت تعريفه في اللغة والاصطلاح وأنواعه بصورة موجزة. ثانيًا : تفسير مبسط لسورة الفرقان، تتاولت فيه: تعريفًا موجزًا للسورة من حيث بيان عدد آياتها وسبب نزولها وأخيرًا المعنى الإجمالي لها. ثم الدراسـة التطبيقية وهي ستة مباحث جاءت تطبيقية محضـة مدعمة في الأسـاس بمفـاهيم نظريـة السـياق وتطبيـق تلـك الأسـس على الآيـات المتضمنة للاختلافات التفيرية في السورة الكريمة عند الإمام الفخر الرازي، وجاءت كما يلي: المبحث الأول: السياق القرآني وأثره في تعيين الأصل الاشتقاقي. 
النيياق القراًأنيه وأثره فهي تعيين المعنص عند الفخر الرازيه

المبحث الثاني: السياق القرآني وأثره في تعيين الزمان.

المبحث الثالث: السياق القرآني وأثره في تعيين دلالة الصيغة.

المبحث الرابع: السياق القرآني وأثره في تعيين المتكلم.

المبحث الخامس: السياق القرآني وأثره في تعيين عودة الضمير •

المبحث السادس: السياق القرآني وأثره في تعيين دلالة المشترك اللفظي.

وانتهت الدراسة بخاتمة توّجت من خلالها أهم ما أسفرت عنه من نتائج.

ثم فهرس المصادر والمراجع.

ولقد اعتمدت على مصسادر ومراجع متتوعـة لإثراء الدراسـة وأهمها كتب

التقسير والمعاجم بالإضافة لعلوم أخرى، كما سيأتي في الفهرس.

والله اسأل التوفيق والسداد وأن يجعل هذا العمل نافعًا لكتابه العزيز، وأن

يرزقني ووالديَّ وأساتذتي الثواب عليه فهو الوهاب المنان. 


\section{التمهميد}

\section{السياقية والفرقان قراءة نظرية تفسيرية}

\section{أولاً : نظرية السياق.}

في هذا التمهيد الموجز سـأتناول المقصـود بلفظ السياق وكيف أصـبح نظرية وأنواعه.

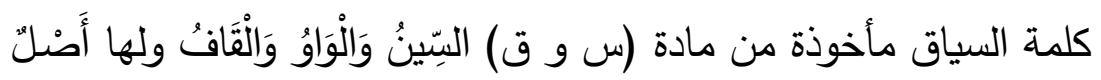

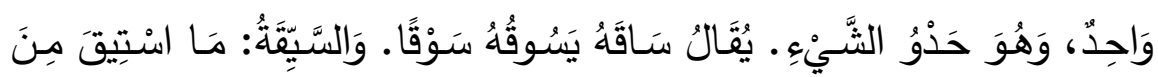

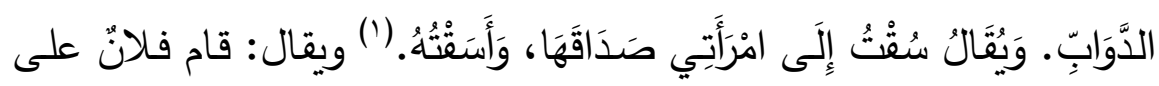

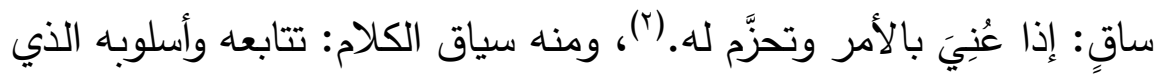
يجري عليه.(r) فهي تدور حول التتابع، ومن تلك الدلالة جاء مفهوم نظريـة السياق وقامت عليها أسسها:

فلفظة السياق تعني في الأصل النسيج، ثم استعملت في معنى الكلمات المصاحبة للمقطوعات الموسيقية ثم صـارت تستعمل في معنى النص، أي:

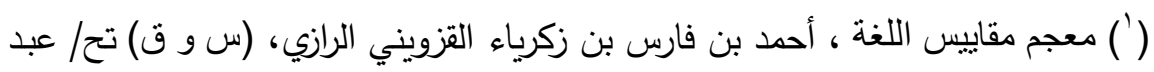

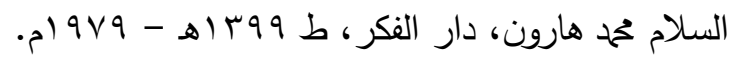

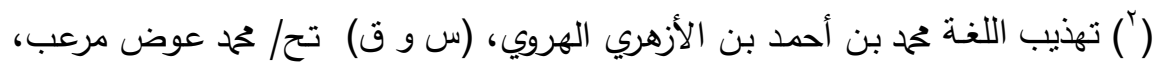

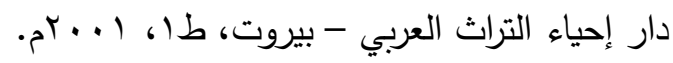

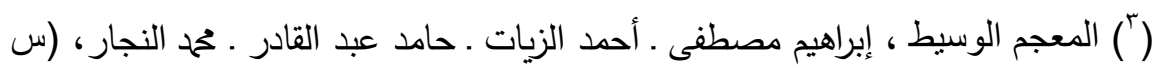
و ق) تح/ مجمع اللغة العربية، بالقاهرة، دار الدعوة. 
تلك المجموعة من الجمل المتراصـة مكتوبـة كانت أو مقروءة(')، ثم أصبح للمصطلح بعد التركيب المعاني الآتية: ما يحيط بالوحدة اللغوية المستعملة في النص. *قيود التوارد المعجمي التي تراعى عند استعمال أكثر من وحدة لغوية. *نص لغوي يتسم بسعة نسبية ويؤدي معنى متكاملًا سواء أكان ذلك

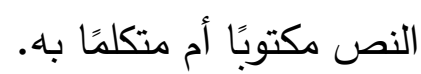
*الأحوال والمواقف الخارجية ذات العلاقة بالكلام.(؟) ويمكن القول بأن هذه المعاني هي أسس النظرية السياقية فهي تعتمد على: * مراعاة السياق اللغوي. * مراعاة الموقف أو السياق الخارجي.

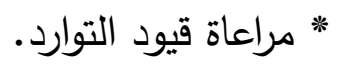
* مراعاة جميع الوظائف التي تتهض بها الوحدات اللغوية.(r)

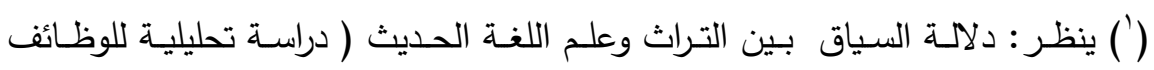

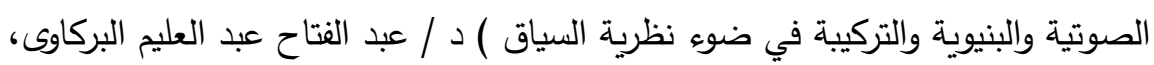

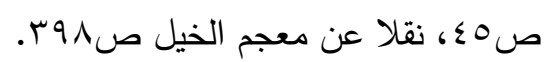

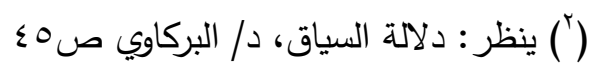

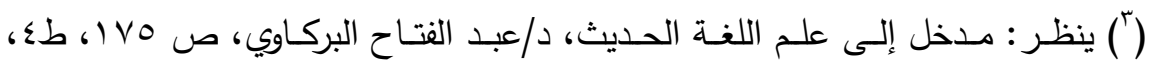

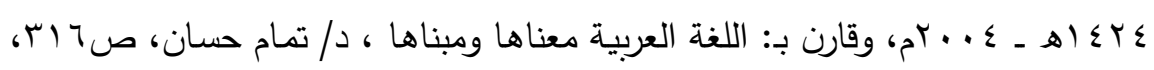
دار الثقافة، المغرب، ـ99 ام. 


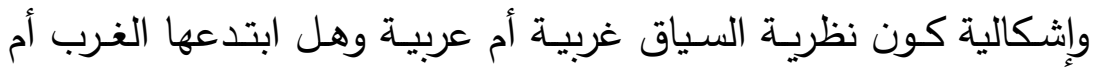

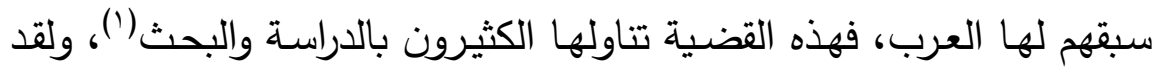

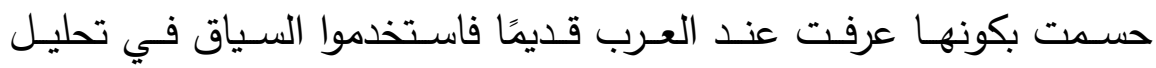
النصوص للتوصل للمعاني المرادة، ومؤلفاتهم حافلة بما يثبت ذلك، فجاء

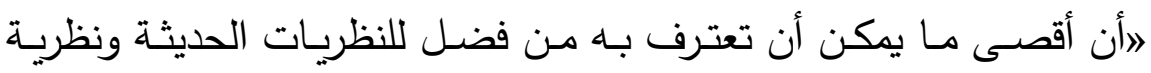
(فيرث) السياقية هو وضع الإطار النظري للفكرة في إطار نظريـة متكاملة

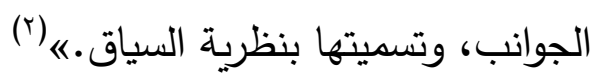
ولقد فصل العلماء في ذكر أنواع السياق فمنهم من قصره على سياق

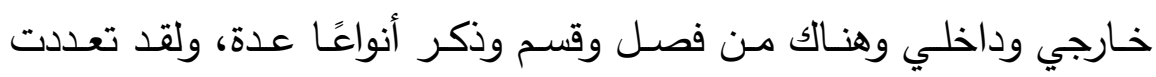
المسميات وإن كان منها ما يعد من باب الترادف، وتعدد المسميات لمعنى

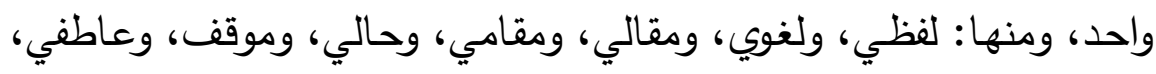

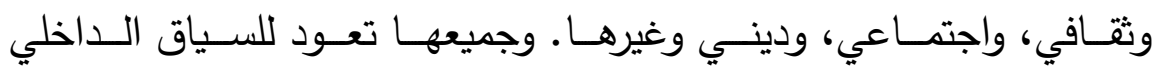
والخارجي، أو اللفظي والمقامي، وفيما يلي تحديد لدفهوم بعض وغيلـ هذه الأنواع

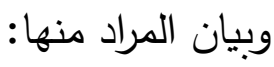

(') ومنعًا لتكرار ما ذكر في مؤلفات عديدة لم أفصل الحديث في هذه القضية لكونها

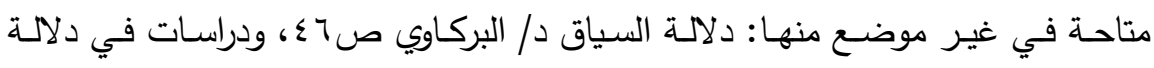

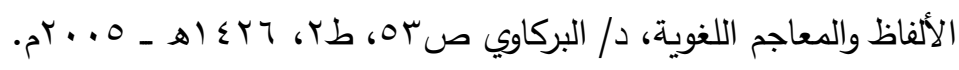

(') أصول النظرية السياقية الحديثة عند علماء العربية ، د/ كحم سالم صالح بحث منثور

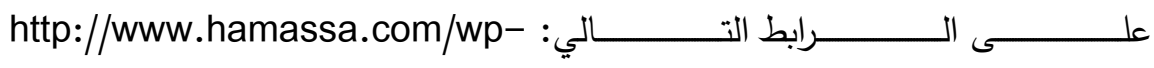
content/uploads/2016/05 


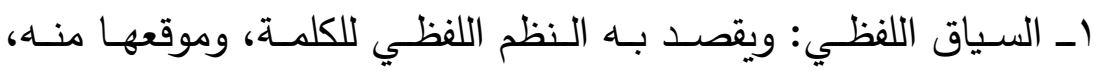
ويشمل: الكلمات، والجمل السـابقة واللاحقة للكلمـة، والنص الذي توجد فيه اللفظة في الجملة، فتكتسب من السياق توجيهًا دلاليًا، وقد تأتي في سياق آخر فتكتسب دلالة أخرى.(')وهذا هو السياق اللغوي بمعناه الواسع. r - السياق الخارجي أو سياق الموقف أو المقامي: وهو الموقف الخارجي الذي يمكن أن تقع فيـه الكلمـة. (r) ومن يرى أن السياق ينقسم فقط للفظي

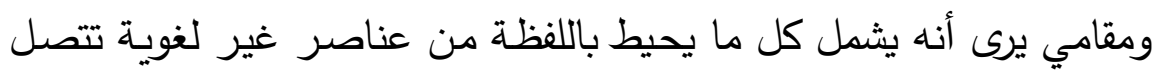

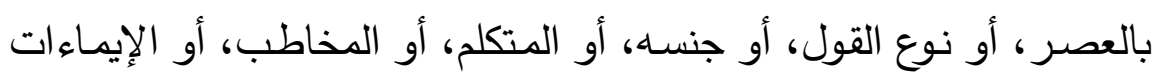
التي تعطي للفظة دلالتها. (r)

ب- السياق العاطفي: وهو يحدد درجة القوة والضـفف في الانفعال، ممـا

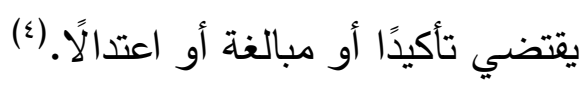

ع- السياق الثقافي: ويقتضـي تحديد المحيط الثقافي أو الاجتماعي الذي

يمكن أن تستخدم فيه الكلمة.(0)

إذن فالسياق كما قال د/ البركاوي: هو ما يشتمل على عناصر دلالية

تستفاد من المقام ومن المقال جميعًا. (')

(') أقسام السياق في الدلالة، د/ سامح عبد السلام محم، بحث منشور على موقع الألوكة على الرابط الآتي: (r) علم الدلالة، د/ أحمد مختار عمر ص الط، عالم الكتب، القاهرة.

$$
\begin{aligned}
& \text { (") (أقسام السياق في الدلالة، د/ سامح عبد السلام مححد }
\end{aligned}
$$

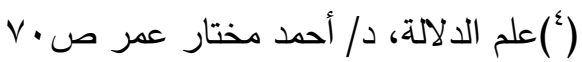

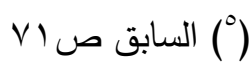


فـالمنهج السياقي المتكامـل في مستوياته المتعددة النحويـة والصــــية

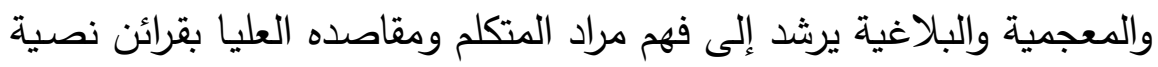

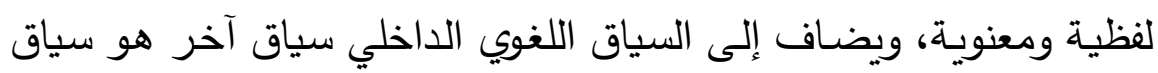

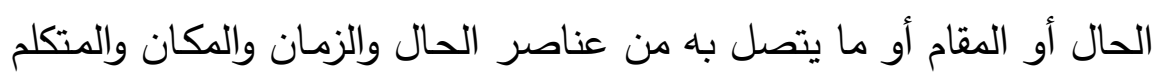

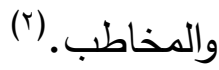

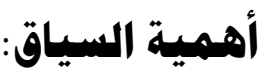

السياق هو الذي يعين الغرض من اللفظ، ويشعر بنوع العلاقة فيه.(") فبواسطته: 》اتعين قيمة الكلمة في كل الحالات.... إذ أن الكلمة توجد في

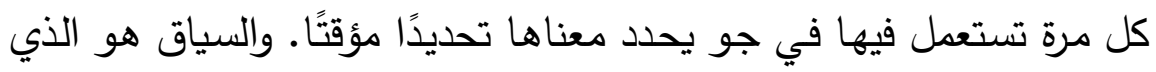

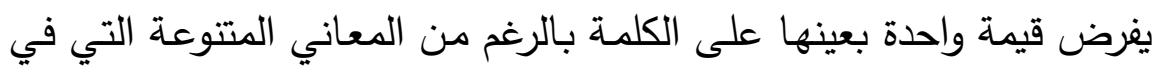

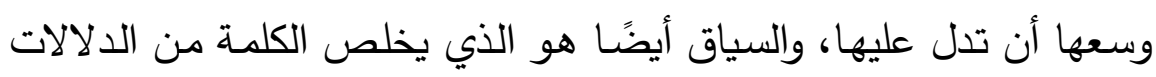

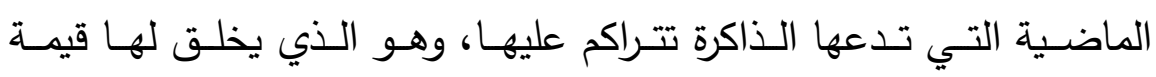
حضورية.《(أن)

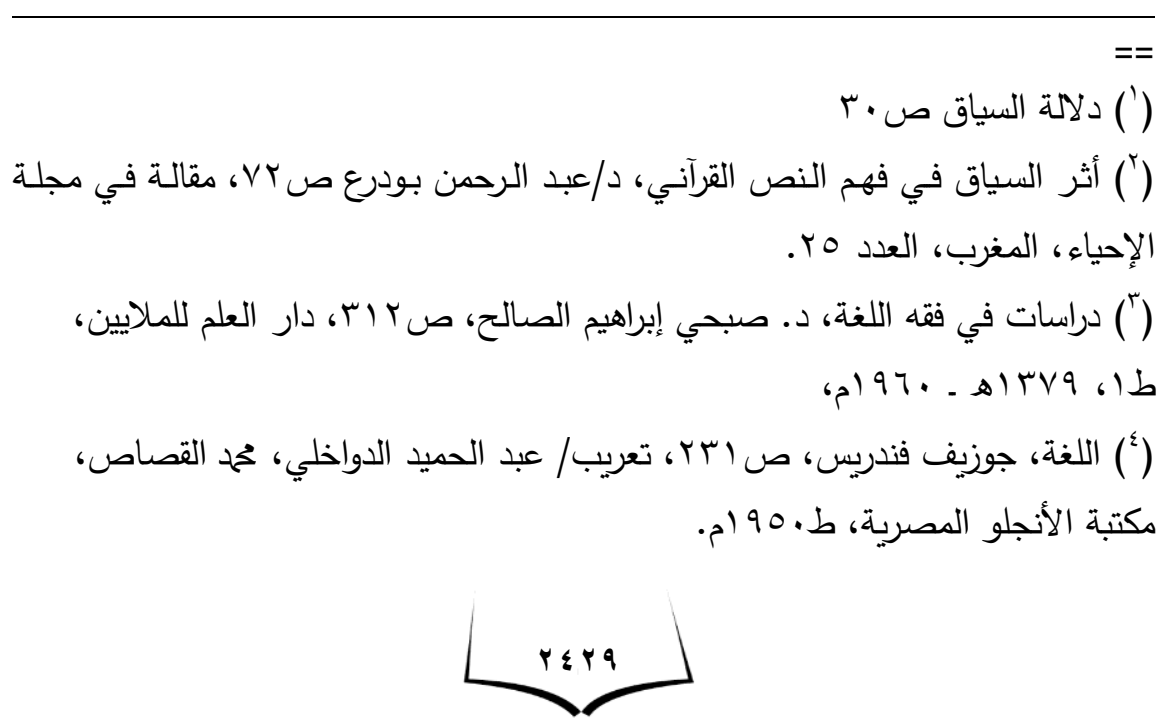


فتكمن أهميـة السياق كمـا ذكرهـا لنا ابن القيم مجملـة في : 》ا تبينين المجمل وتعيين المحتمل والقطع بعدم احتمال غير المراد وتخصيص العام

وتقييد المطلق وتتوع الدلالة.ب(')

ومجال دراستنا هنا هو أهمية السياق في تعيين المحتمل من المعاني، وذلك مـا حملني على تأخير كـلام ابن القيم في أثناء حديثي عن أهميـة السياق وإن كان سابقًا على ما عداه، ولكن رغبة مني في ربط تلك المقولة عن فائدة السياق بصلب الدراسة، وجعلها توطئة لها حتي ندخل مباشرة في الدراسة التطبيقية بعد ما سيأتي من قراءة تفسيرية موضوعية لسورة الفرقان: ثانيًا: سورة الفرقان قراءة تفسيرية. سورة الفرقان سورة مكيّة، وهي ثلاثة آلاف وسبعمائة وثلاثة وثلاثون حرفًا،

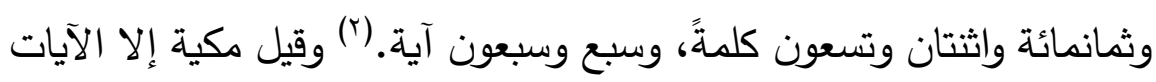

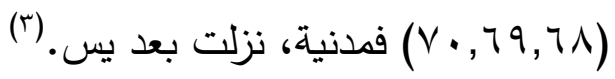

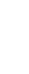

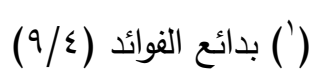

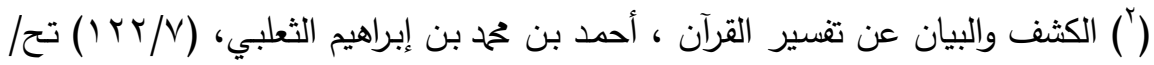

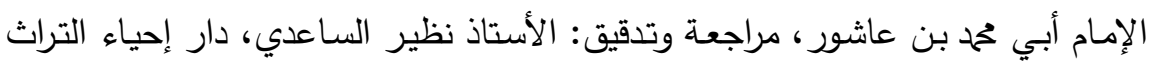

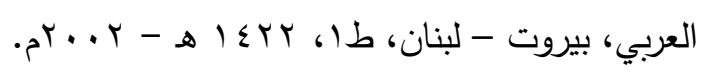

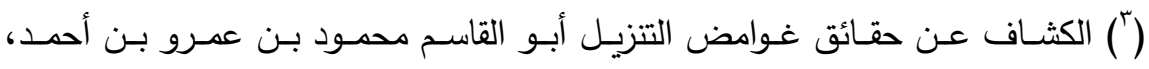

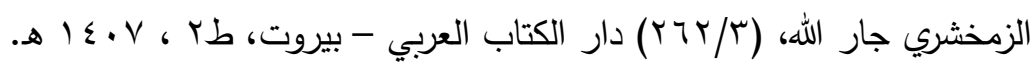




\section{مقصدها:}

مقصود هذه السورة ذكر عظم القرآن، وذكر مطاعن الكفار في النبوة والرد على مقالاتهم (') حيث تكلم سبحانه في هذه السورة أولًا في التوحيد لأنها أقدم وأهم، ثم في النبوة لأنها الواسطة، ثم في المعاد وختم السورة بصفات العباد المخلصين الموقنين فما أشرف هذه المطالب وما أحسن هذا الترتيب.(r)

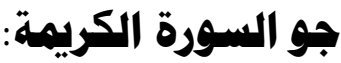

هذه السورة تبدو كلها وكأنها إيناس لرسول الله- صلّى الله عليه وسلّم وتسرية، وطمأنـة لـه وتقويـة وهو يواجـه مشركي قريش، ووقوفهم في وجـه

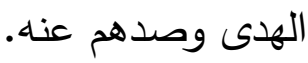

فهي في لمحسة منها تصـور الإينـاس اللطيف الذي يحيط بـه الله عبده ورسوله وكأنما يمسح على آلامه ومتاعبه مسحا رفيقًا ويهدهد قلبه، ويفيض عليه من الثقة والطمأنينة، وينسم عليه من نسائم الرعاية واللطف والمودة. وهـي في اللمحسة الأخرى تصـور المعركـة العنيفـة مـع البشـرية الضـالة الجاحدة المشاقة لله ورسوله، وهي تجادل في عنف: إنها البشرية التي تقول

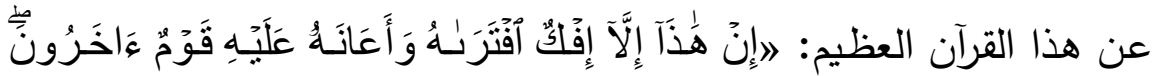

(') الجامع لأحكام القرآن ( تقسير القرطبي)، أبو عبد الله محم بن أحمد بن أبي بكر بن

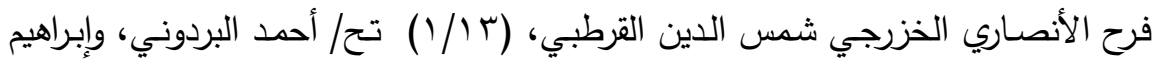

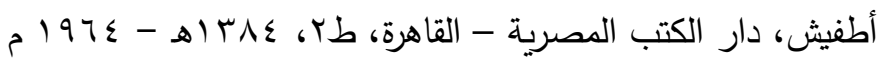

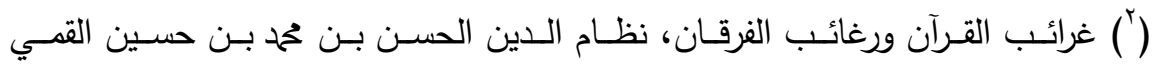

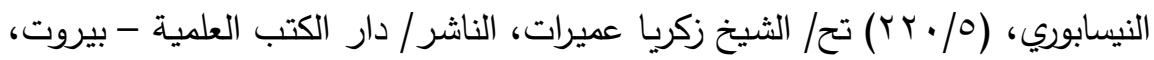


«(الفرقان \&)، وهي هي من قديم كما يرسمها سياق السورة من عهد نوح إلى موقفهـا هذا الأخيـر مـع رسـولها الأخير . فلقد اعترض القوم على بثـرية

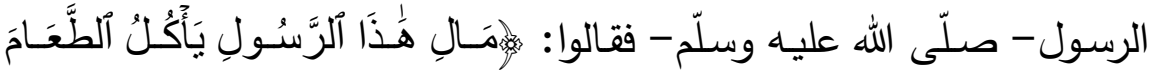

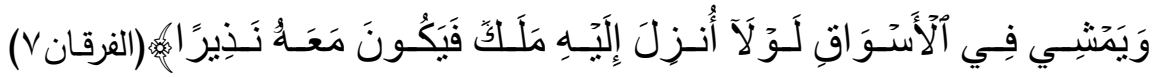

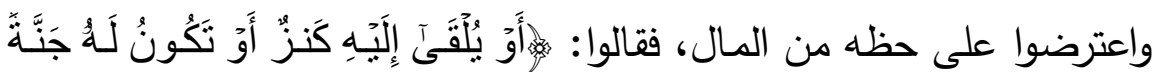

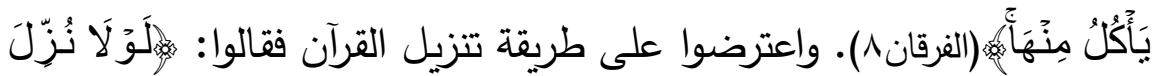

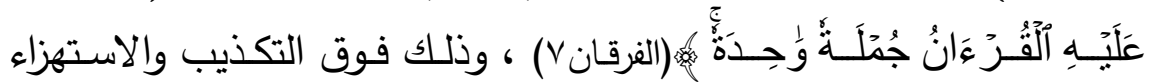
والافتراء الأثيم.

ووقف الرسول - صلّى الله عليه وسلّم - يواجه هذا كله، وهو وحيد مجرد من الجاه والمـال، ملتزم حده مـع ربـه لا يقترح عليه شيئا، ولا يزيد على أن يتوجه إليه مبتغيًا رضاه، فيؤويها ربها إلى كنفه، ويمسح على آلامـه ومتاعبه، ويهون عليه مشقة ما يلقى من عنت القوم وسوء أدبهم وتطاولهم عليه، بأنهخ يتطـاولون على خالقهم ورازقهم، وخالق هذا الكون كله ومقدره ومدبره. فـلا

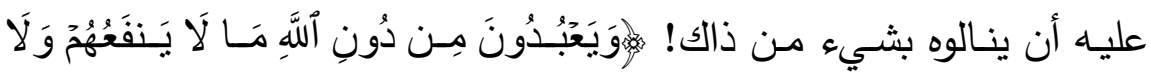

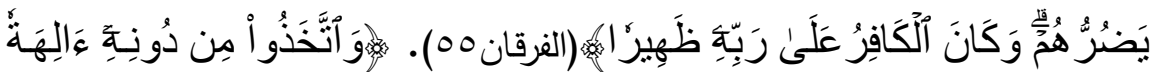

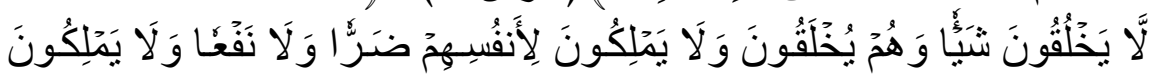

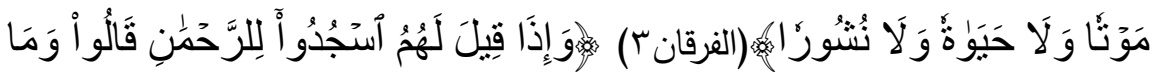

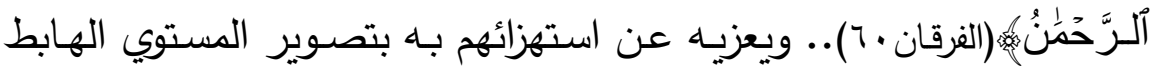

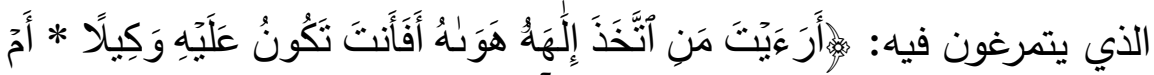

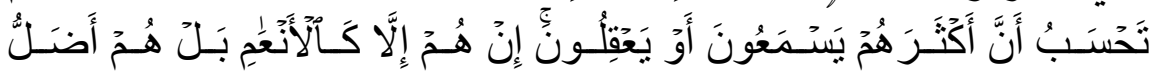

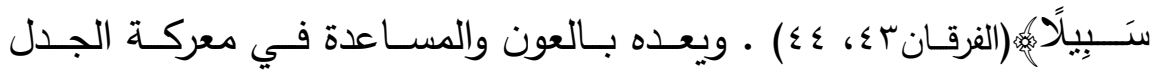

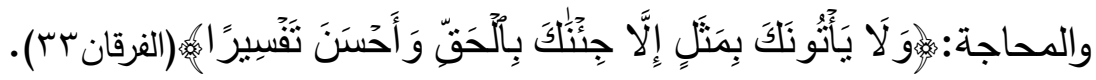




\section{مجلةققطاع كليات اللفة العريية والشعب المناظرة لها العذد [rا]}

وفي نهاية المعركة كلها يعرض عليه مصـارع المكذبين من قبل: قوم

موسى ونوح وعاد وثمود وأصحاب الرس وما بين ذلك من قرون، ويعرض دان

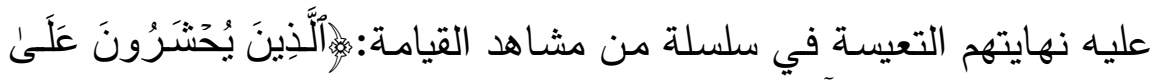

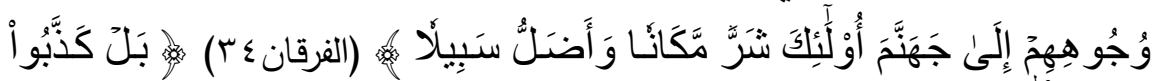

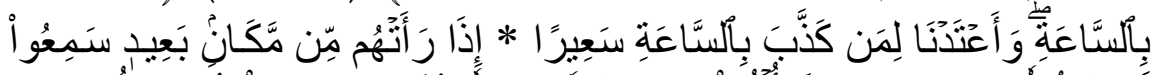

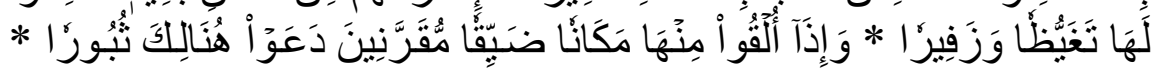

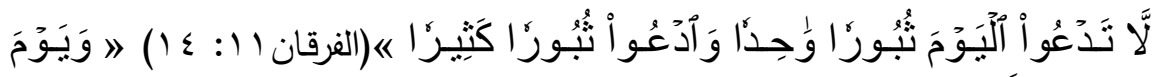

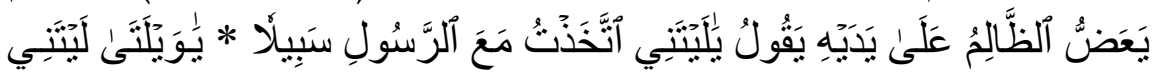

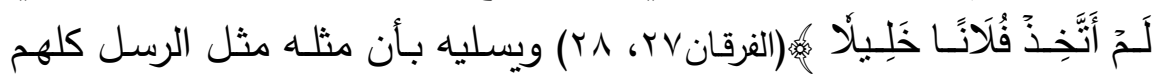

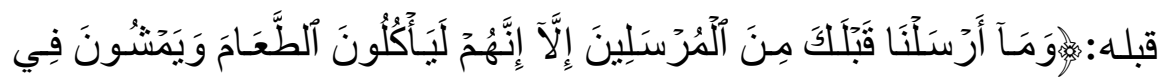

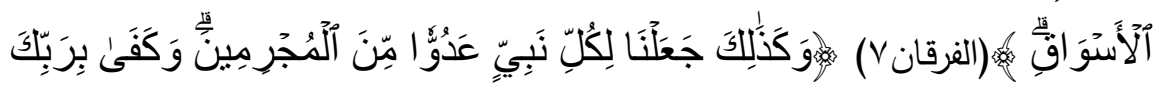

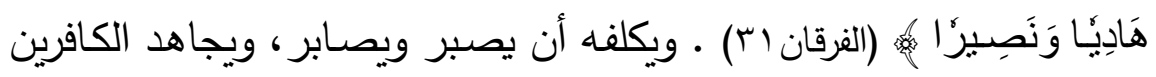
بمـا معـهـ مـن قرآن، واضـح الحجـة قوي البرهـان عميق الأثر في الوجدان:

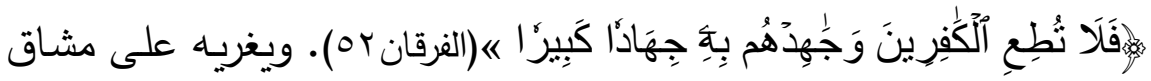

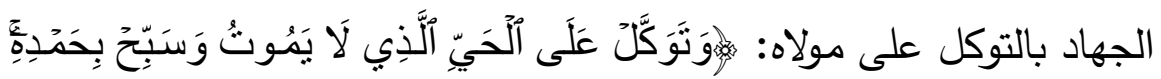

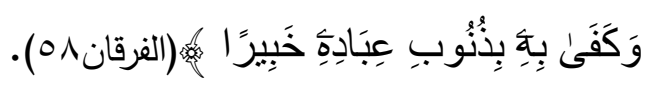

وهكذا تمضي السورة: في لمحة فيها إيناس وتسرية وعطف وإيواء من الله لرسوله. وفي لمحة فيها مشاقة وعنت من المشركين لرسول الله- صـلّى الله عليه وسلّم - وتتبير ونكال من الله الكبير المتعال. حتى تقرب من نهايتها، ونها،

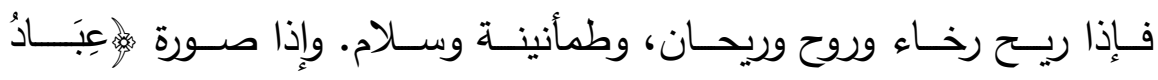

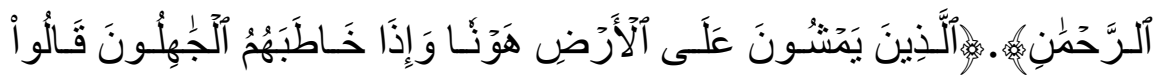

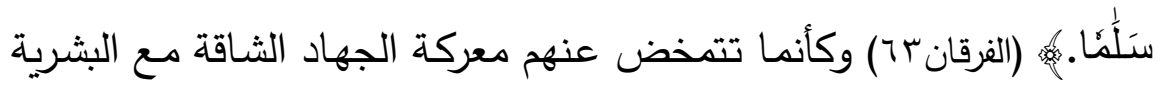
الجاحدة الضـالة المعانـدة المشـاقة وكأنمـا هـم الثــرة الحلـوة الجنيـة الممثلـة 
للخير الكامن في شجرة البشرية ذات الأشوالك. وتختم السورة بتصوير هوان

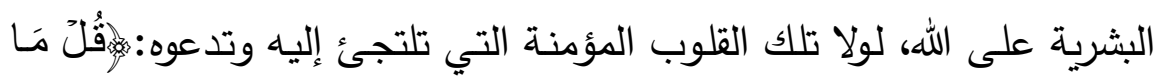

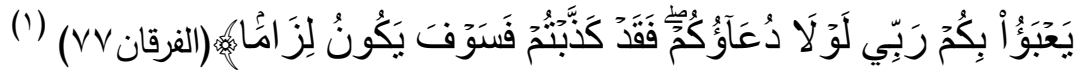
تلك كانت قراءة تفسيرية موضوعية سريعة لسورة الفرقان، للوقوف على أهم ملامحها وموضوعاتها.

وعند النظر لتفسيرها عند الإمام الفخر الرازي نجد بعض المواضـع التي

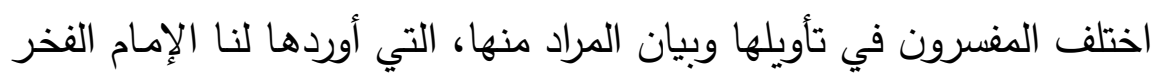
الرازي في تفسيره (مفاتيح الغيب)، ولتعيين أحد تلك الاحتمالات الواقعة في

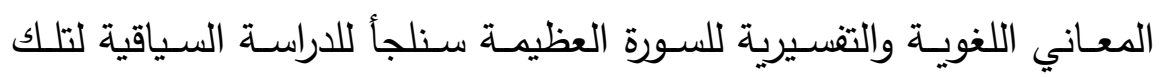
المواضع القرآنية، والتي سنستعين فيها بالسياقات الخارجية والداخلية لتحليل تلك المواضع والوقوف على المراد منها، وذلك في المباحث الآتية:

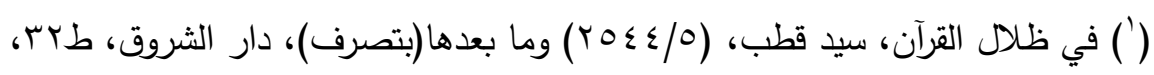
. 


\section{المبحث الأول}

\section{السياق القرآني وأثره في تعيين الأصل الاشتقاقي}

من القضايا التي تحتاج للسياق للوقوف عليها، وتحديد المراد منها الأصل الاشتقاقي، فالاختلاف في الأصل الاشتقاقي للألفاظ، ولاسيما الواردة في لوني النصـوص القرآنيـة لابـد من الركون فيـه للسياق، وفي هذا المبحث سـأقوم بإبراز دور السياق في الترجيح بين المشتقات المختلف فيها للفظة الواحدة والواردة في تفسير سورة الفرقان للإمام الفخر الرازي، مع تتبع آراء اللغويين والمفسرين فيها وترجيح اشتقاق بعينه بمعونة السياق القرآني:

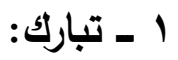

قـال تعـالى :

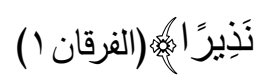

مـن المواضـع التـي اختلف فيهـا المفسـرون الأصـل الاشـتقاقي للفظـة (تبارك) الواردة في السورة الكريمـة، ولقد ذكر لنـا الإمـام الفخر الرازي هذا الاختلاف دون أن يـرجح رأيًا بعينـه، وإن كان اسـتخدمَ أحد المعنيـين في ولي مواضع أخرى في السورة الكريمة سيأتي بيانها كسياق لغوي يرشح ما نذهب لـانب إليـه مـن المشتقات، وفيمـا يلي بيـان لرأي اللغويين والمفسرين في أصـلها

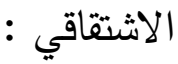

ذكر الإمـام الفخر الـرازي في (مفـاتيح الغيـب) أن لفظـة (تبـارك) إمـا

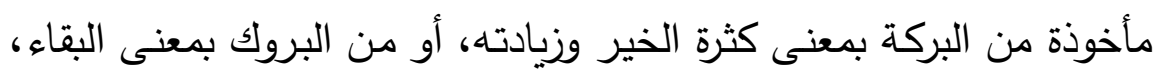


فيقول: 》اقال الزجاج تبارك: تفاعل من البركة، والبركة كثرة الخير وزيادته(1) وفيه معنيان: أحدهما: تزايدَ خيرُه وتكاثر ... والثاني: تزايد عن كل شيء وتعالى عنه في ذاته وصفاته وأفعاله... وقال آخرون: أصل الكلمة تدل على البقاء، وهو مأخوذ من بروك البعير ، ومن بروك الطير على الماء، وسميت البِرْكة بِرْكة لثبوت الماء فيها، والمعنى أنهاء سبحانه وتعالى بـاق في ذاته أزلًا وأبدًا ممتنع التغير وباق في صفاته ممتنع التبدل، ولما كان سبحانه وتعالى لئى هو الخالق لوجوه المنافع والمصـالح والمبقي لها وجب وصفه سبحانه بأنـه

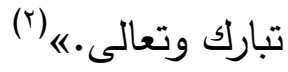
التحليل السياقي: - n - n

نرى في النص السابق أن الإمام الرازي أورد لنا قولين في أصل اشتقاق لفظـة (تبـارك) دون ترجيح بينهــا، وسـنقوم فيمـا يلـي بالبحـث في أقوال

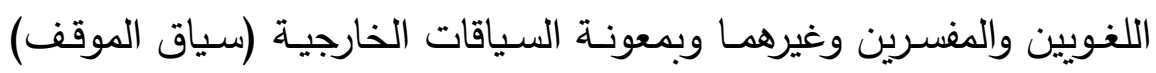
والسياقات الداخلية (السياق اللغوي) لنرى أي القولين الأقرب لمقصد السورة ولمدين الكريمة، ولكن قبل ذلك فلنبدأ ببيان أصل اللفظة وما قاله أهل اللغة فيها: بالبحث عن المعنى المحوري لمادة (ب ر ك) نجدها تدل على الثبوت

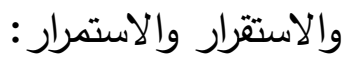

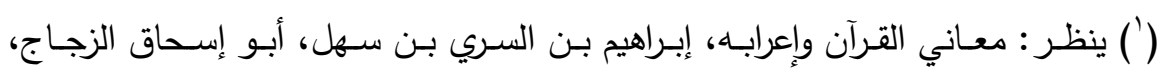

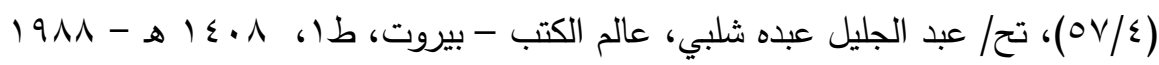

(r) مفاتيح الغيب، أبو عبد الله محمد بن عمر بن الحسن بن الحسين التيمي الرازي الملقب

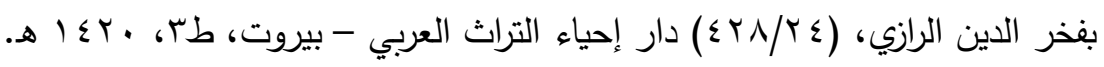


فها هو ذا الراغب يقول فيها: 》أصل البَرْكَ صدر البعير وإن استعمل

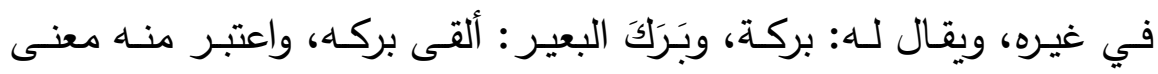

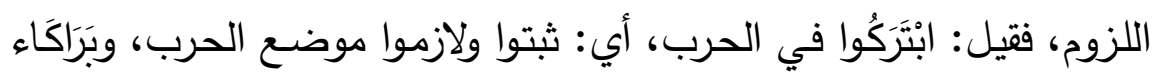

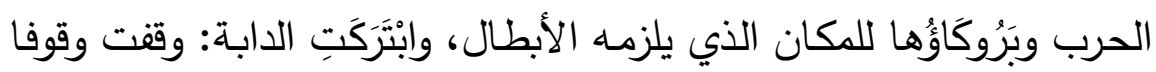

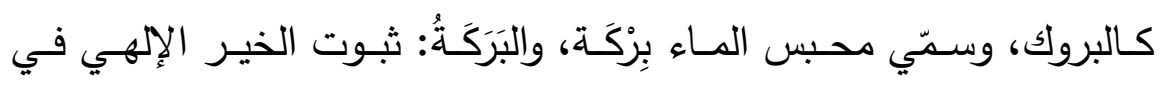

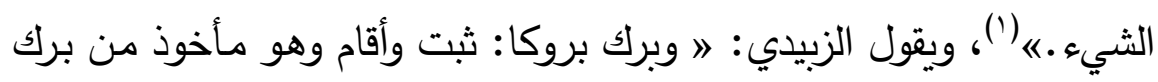

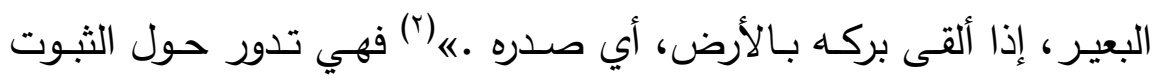
والاستقرار عندهما.

ونجد د/جبل يصرح بدلالتها على الثبوت والاستقرار ويضيف دلالتها

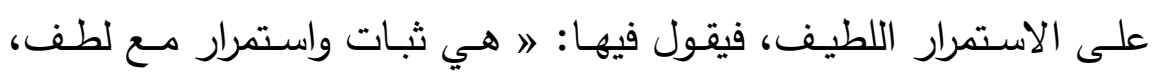

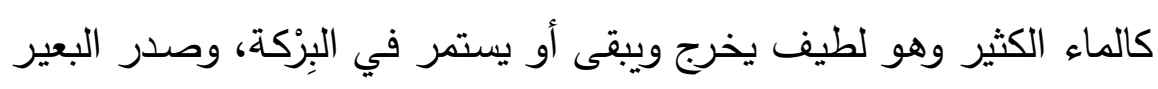

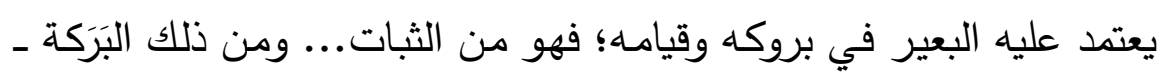

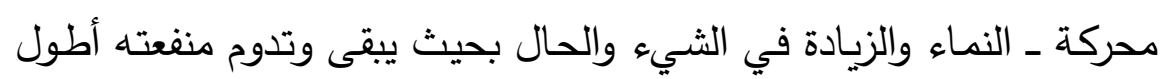

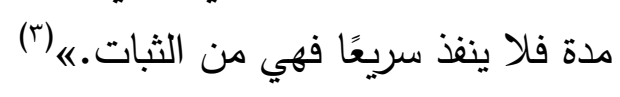

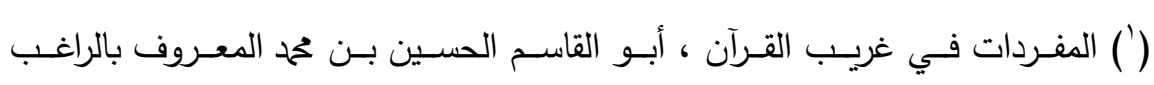

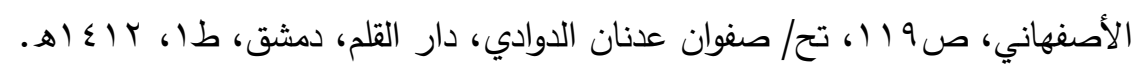

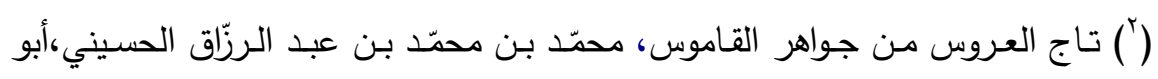

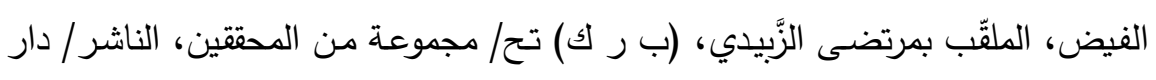
الهداية. (") المعجم الاثتقاقي المؤصل لألفاظ القرآن الكريم، د/ محم حسن حسن جبل، ص9 1 .

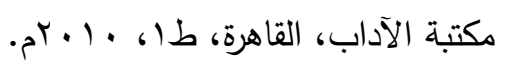


هذا هو رأي أهل اللغة في أصل دلالة البركة والبروك فهما يدلان على ثبوت واستقرار واستمرار ·

وفيما يلي سنقوم بالبحث عن لفظة تبارك عند علماء اللغة لنقف على أصل اشتقاقها حتى يتسنى للبحث تعيين أحد قولي الإمـام الرازي كأصل لاشتقاقها :

يقول ابن دريد في تفعير لفظة تبارك: الوقَد تكلم قوم في قَوْلهم: تبَارك

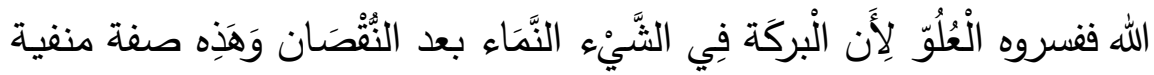

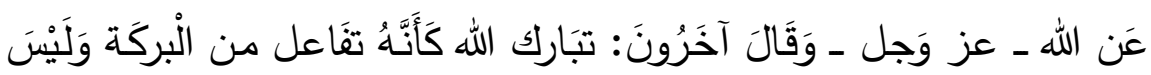

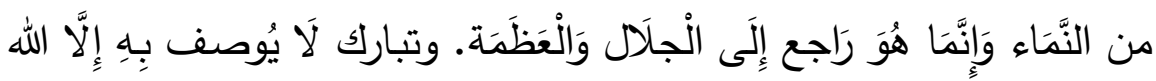

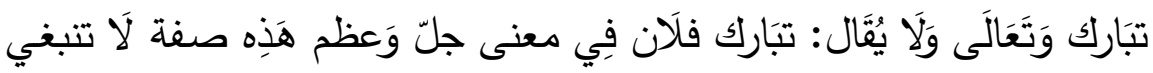

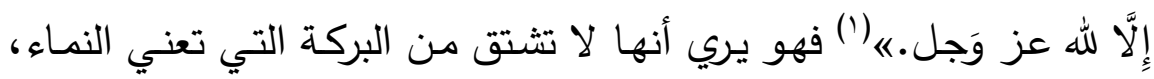
وإنما هي جاءت بصيغة تفاعل للدلالة على اكتساب البركة من الخالق ـ جل وعلا ـ لكل من يقترن بها فهي صفة تعظيم خاصة بالخالق، ف اهعنى تبارك اسمك تفاعل من البركة أي البركة تُكسب وتُنال بذكر اسمك.یه (؟) ولكن هناك من اللغويين من لا يمنع دلالة (تبارك) على النماء والعلو

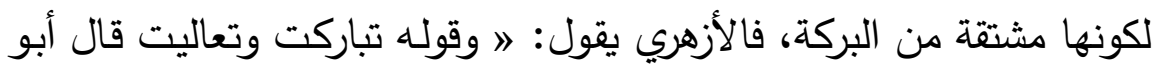
العباس تبارك الله، أي: تعالى الله، والبركة النماء والعلو، وقال أبو بكر بن

(') جمهرة اللغة، أبو بكر محمد بن الحسن بن دريد الأزدي، (ب ر ك) تح/ رمزي منير

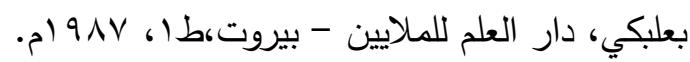

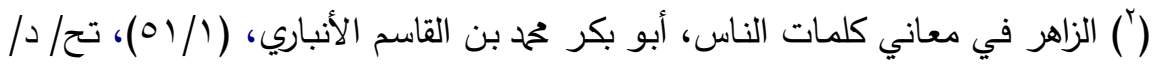

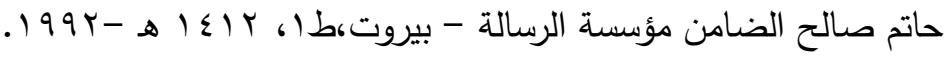


الأنباري: تبارك الله أي يتبرك العباد بتوحيده وذكر اسمه..ه(') وهناك من

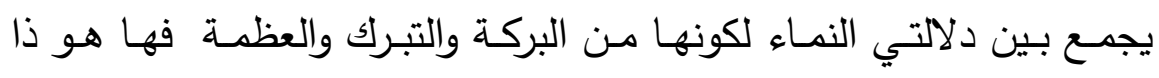

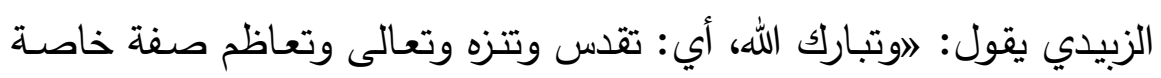

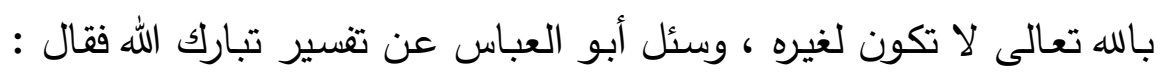
ارتفع ، وقال الزجاج: تبارك : تفاعل من البركة، كذلك يقول أهل الهل اللغنة .

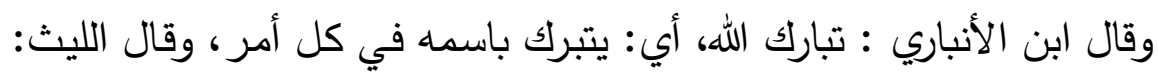

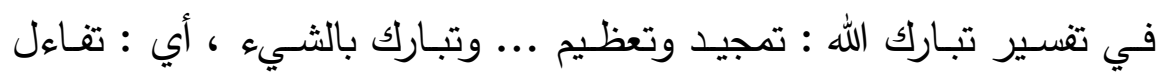

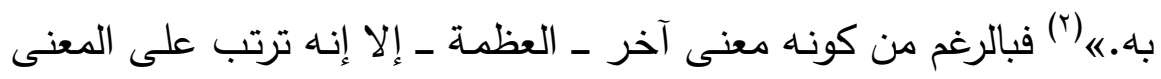

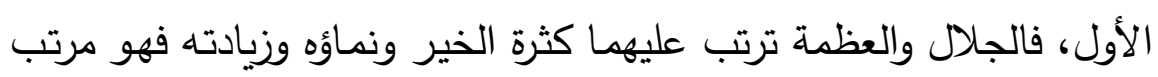

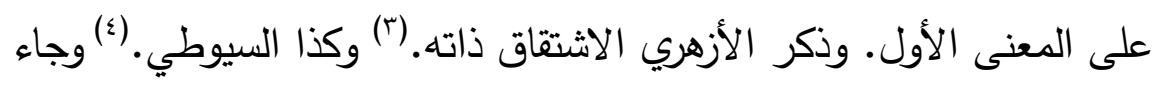

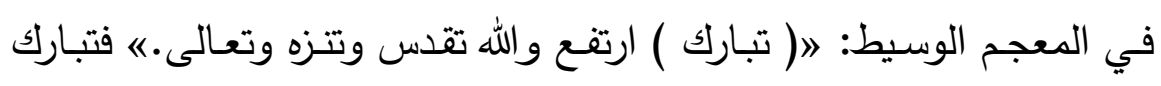

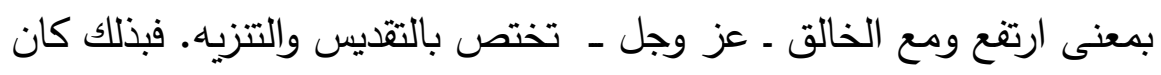

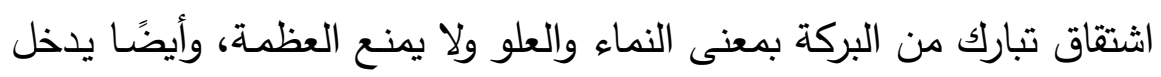

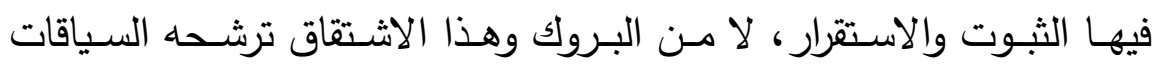

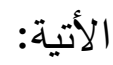

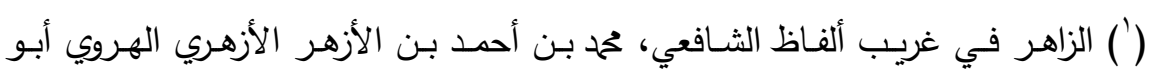

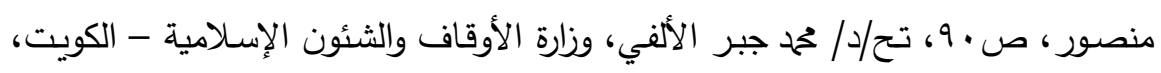

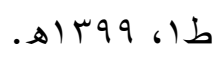

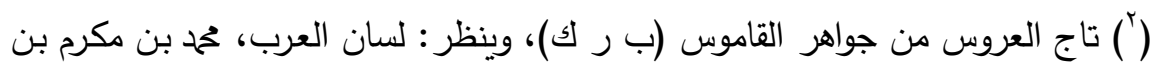

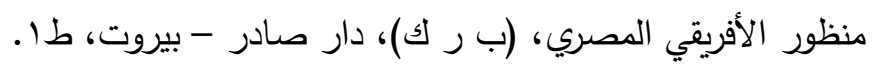

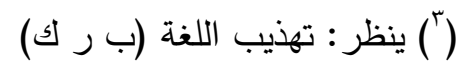

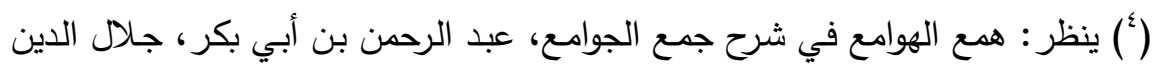

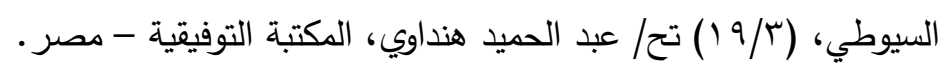


أولاً: السياق غير اللغوي الخارجي : السورة الكريمـة نزلت وكأنها إيناس لرسول الله- صلّى الله عليه وسلّم - وتسرية، وطمأنـة له وتقويته وهو يواجـه مشركي قريش، وعنادهم له. (') فذكر الحق فيها أنواعًا من الخير التي منَّ بها على رسوله، وعلى عباده المؤمنين، في معرض التسرية والطمأنة له ـ صلى لـ كلى الله عليه وسلم - ولا خير أكثر بركةً من تنزيل كتابه العزيز الهادي لطريق الحق، ففيه نعيم الدنيا وسعادة الأخرة. يؤكد ذلك الهناسبة أول هذه السورة لآخر ما قبلها أنه لما ذكر وجوب مبايعة المؤمنين للرسول وأنهم إذا كانوا معه في أمر مهم توقف انفصال واحد منهم على إذنه وحذر من يخالف أمره وذكر أن له ملك السموات والأرض وأنه تعالى عالم بما هم عليه ومجازيهم على ذلك، فكان ذلك غاية في التحذير والإنذار ناسب أن يفتتح هذه السورة بأنه تعالى منزه في صفاته عن النقائص كثير الخير ، ومن خيره أنـه نزل الفرقان على رسوله منذرًا لهم فكان في ذلك إطماع في خيره وتحذير من

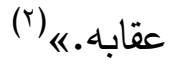

\section{ثانيًا: السياقات اللغوبة :}

بما أن الآيات القرآنية يفسر بعضها بعضًا فيمكن تقسيم الآيات التي تدل على الخير والبركـة، بناء على السياق القرآني، والتي ترشـح اشتقاق لفظـة

$$
\text { (تبارك) من (البركة) إلى : }
$$

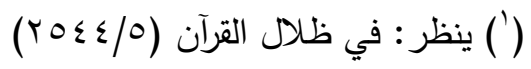

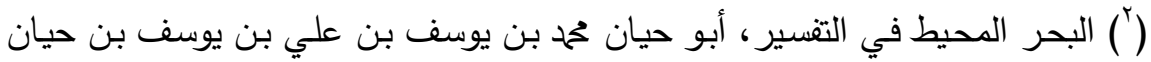

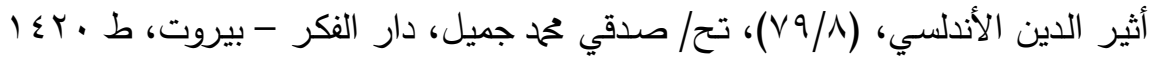


أـ السياق اللفوي الكلي لآيات القرآن الكريم:

بالنظر في آيات القرآن الكريم تجد كتير منها تدل على الخير الوفير

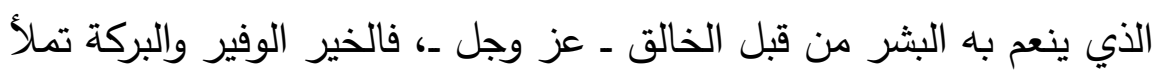
الكون، والآيات القرآنية التي تتحدث في هذا السياق المقاصدي نجدها كثيرة

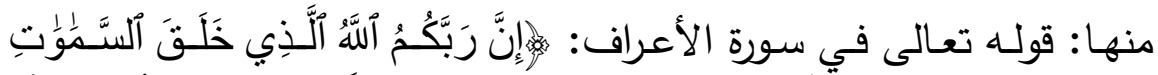

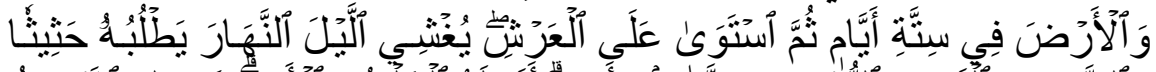

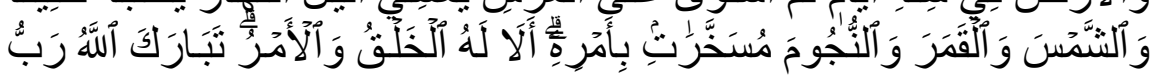

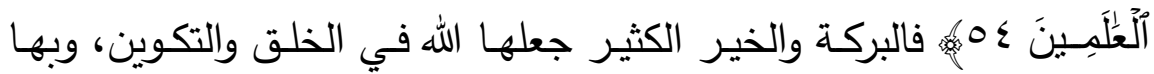

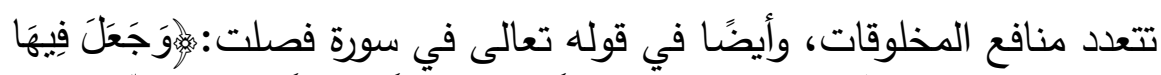

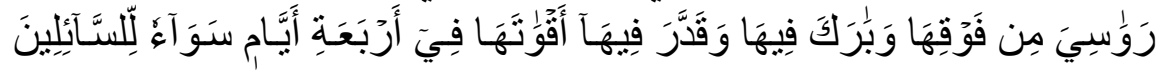

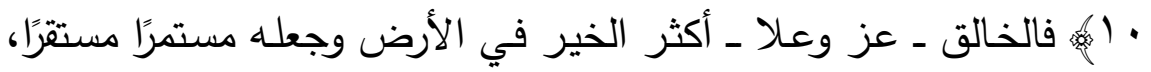
فهو لا يضيق بأحد من خلقه بل يستوعب جميع الأمم على مر الأزمان المان. ولما كان الماء هو سبب الحياة جاء النص على بركة المطر وعظيم نفعه بله

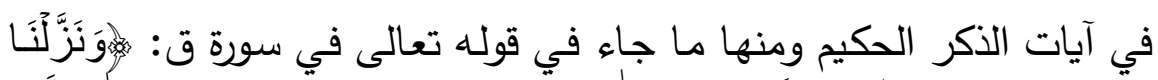

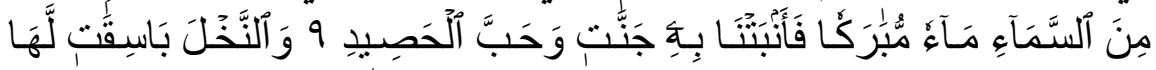

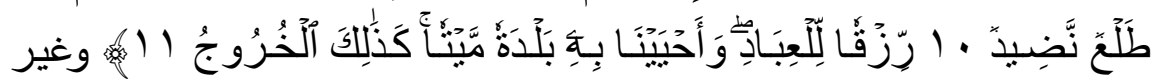

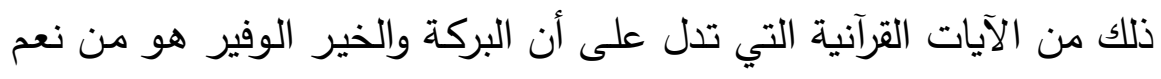

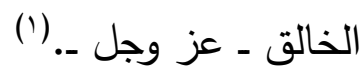

(') ينظر : البركة في القرآن الكريم دراسة موضوعية، د. وفاء بنت عبد الله الزعاقي، مجلة جامعة الملك سعود، م\& ب، العلوم التربوية والدراسات الإسلامية (ب)، الرياض

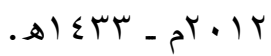


وذلك يكون في الآيـات الأخرى للسورة ذاتها، التي جـاءت فيها لفظـة (تبارك) مشتقة من (البركة) وهو كثرة الخير للعباد سواء صرح الإمام الرازي

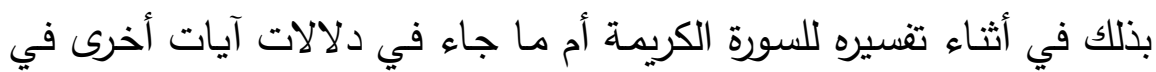
السورة ومن هذه السياقات اللغوية الجزئية:

1 ـ ما ذكره الإمام الرازي في تفسير السورة الكريمة في موضعين آخرين

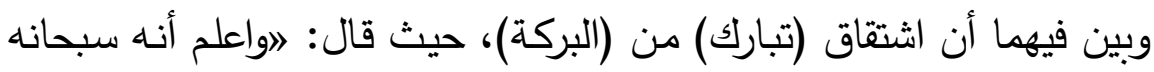

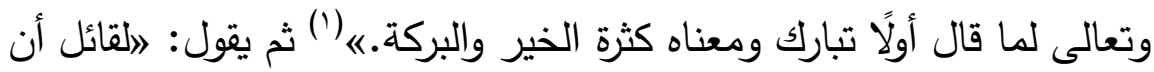

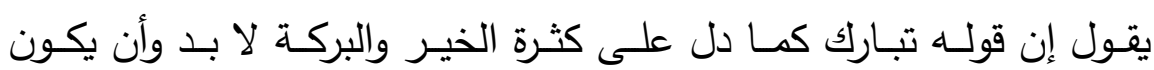

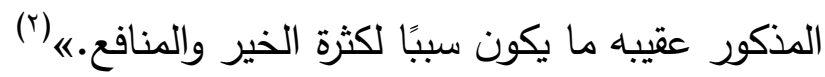
r ـ مجيء بعض آيات السورة الكريهة التي تبين بعض صور الخير

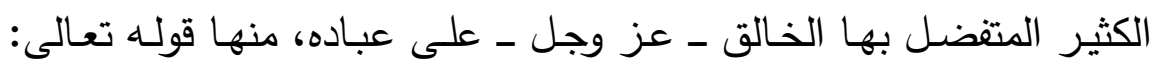

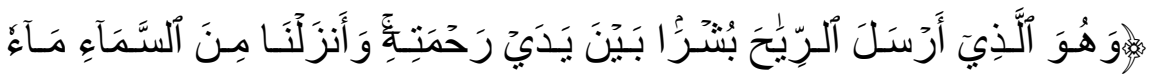

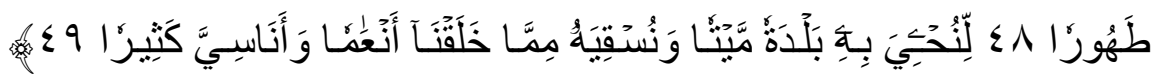

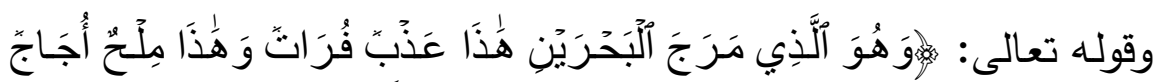

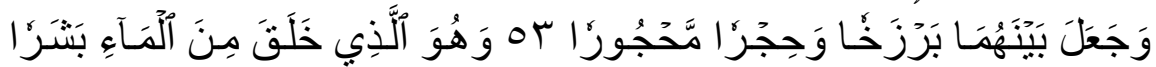

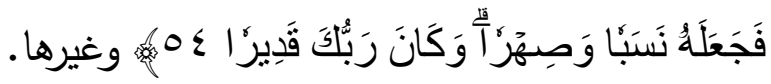

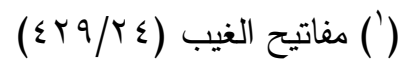

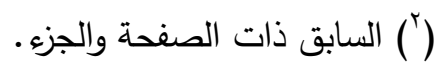




\section{ثم ننتقل بعض ذلك إلى السياقات اللغوية الأخرى:}

*منها ما ورد في كتب أهل اللغة والمفسرين وغيرهما فاغلبهم أشاروا إلى

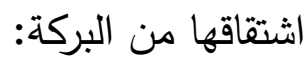

فمن المفسرين الطبري حيث قال: اقال أبو جعفر : تبارك: تفاعل من

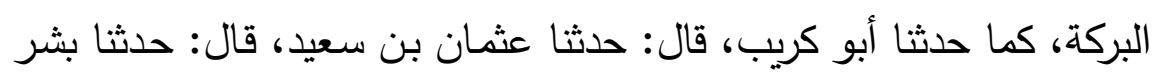

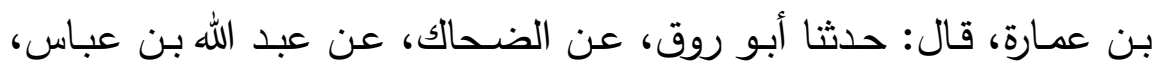
قال: تبارك: تفاعل من البركة. وهو كقول القائل: تقدّس ربنا.ی)(') وذكر أبو حيان لنا قول ابن عباس والحسن والنخعي فيه، فقال: قد قالوا هو من البركة وهي التزايد في الخير من قبله، فالمعنى زاد خيره وعطاؤه وكثر.(r) وصساحب هن

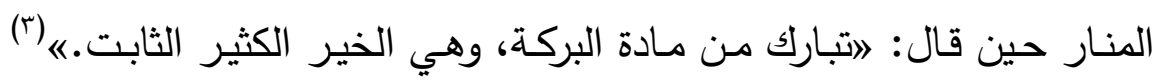
وغيرهم. (๕) ( )

(') جامع البيان في تأويل القرآن، محمد بن جرير بن يزيد بن كثير بن غالب الآملي، أبو

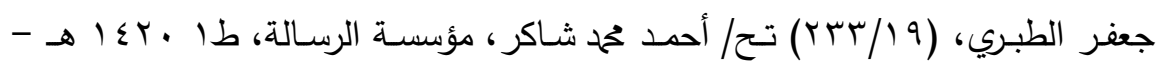
....

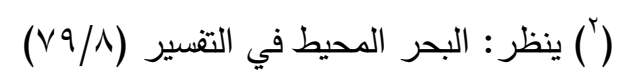

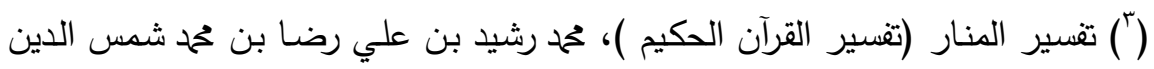

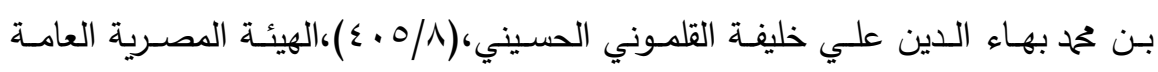

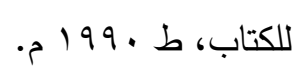

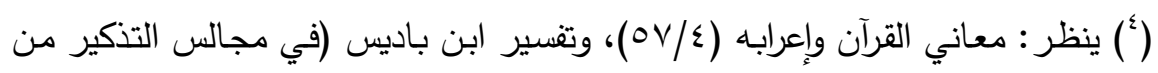

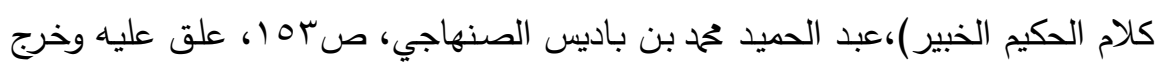

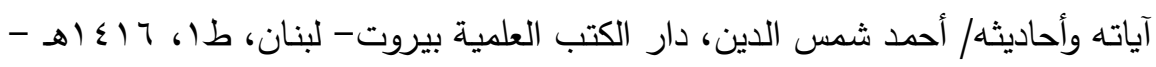


وجـاء في شـروح الحـديث: 》 تبـارك: تفاعـل مـن البركـة، وهـي الكثرة

والاتساع، ومعناه: تعالى وتعظم، وكثرت بركته في السموات والأرض، إذ بـه

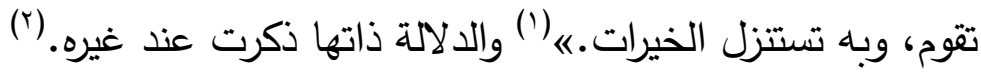
وبإمعـان النظر فيمـا قالـه ابـن دريـــ والعيني ترى الباحثة أن هذا هـو المعنى الأصلي والأساسي. وأيضًا جاء اشتقاق تبارك من البركة لدى الفقهاء، فمنهم شيخ الإسـلام

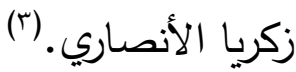

مما سبق يتبين أن السياق يرجح اشتقاق لفظة (تبارك) من (البركة) لا من (البروك) باعتبارها أكثر مناسبة لغرض السورة، وأيضًا لفظة البركة تضم بين طياتها دلالتة البروك كما جاء في قول الإمـام الرازي حين قال: الوأمـا تعاليه عن كل شيء في ذاته، فيحتمل أن يكون المعنى جل بوجوب وجوده

(') شرح سنن أبي داود، أبو محمد محمود بن أحمد بن حسين الغيتابى الحنفى بدر الدين

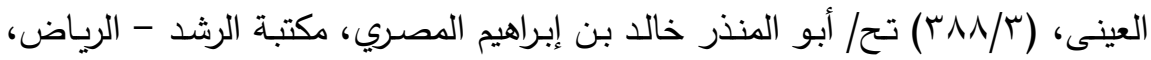

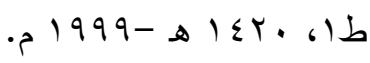

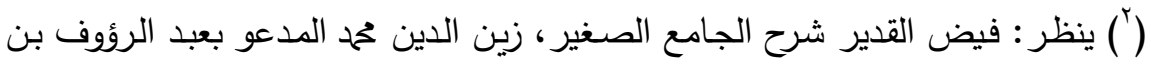

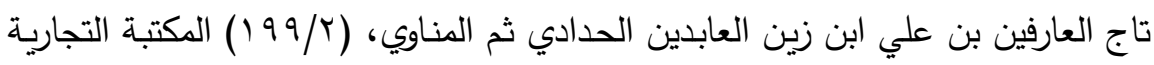

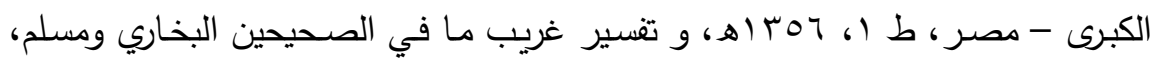

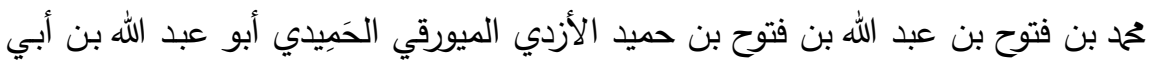

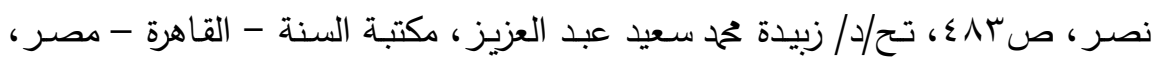

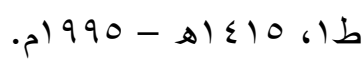
(") ينظر : حاشية الجمل على المنهج ، لثيخ الإسلام زكريا الأنصـاري، الثيخ سليمان

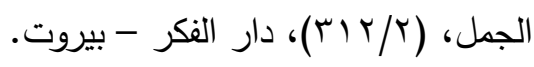


وقدمـهـ عن جـواز الفنـاء والتغير عليـه.ب(') فعـدم جـواز الفنـاء للخـالق يفيد الثبوت والبقاء له، وأيضًا ما قاله د/ جبل في دلالة البركة، فقال: \ البركة: النماء والزيادة، في الثيء والحال بحيث يبقى وتدوم منفعته أطول مدة فلا ينفذ سريعًا فهي من الثبات.«(r) وتلك دلالة البروك كما سبق. فاشتقاق تبارك من البركة بمعنى كثرة الخير وزيادته أقرب للمعنى هنا، ويرشح ذلك عدة سياقات داخلية وخارجية.

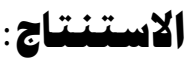

مما سبق نرى أن لفظة (تبارك) تؤخذ من اشتقاقيين هما: الأول: من البركة، ويتقرع لمعنيين هما الخير ونماؤه وزيادته وكثرته، والآخر : هو التعالي والجلال والعظمة. الثاني: من البروك.

ومـن خـلال السـياق يمكنـــا تـرجيح الأصـل الاشـتقاقي الأول (البركـة) وبخاصــة المعنـى الثاني على أن يكـون المعنى الأول مترتبَّا عليـه، فكثرة الخير وزيـادة لا تتأتى إلا من صـاحب العظمة والجلال وهو الخالق ـ عز وجل - ، وفي السورة سياقات لغوية كثيرة تؤيد هذا منها:

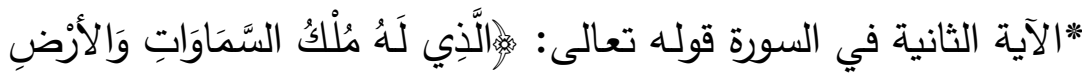

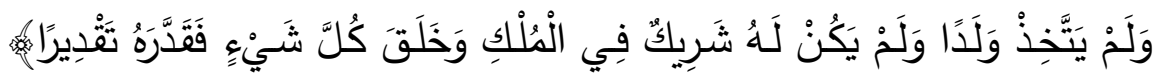

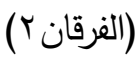

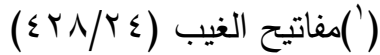

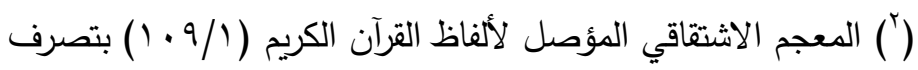




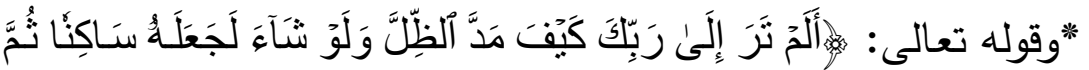

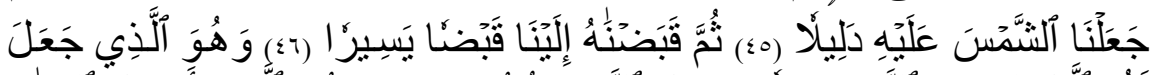

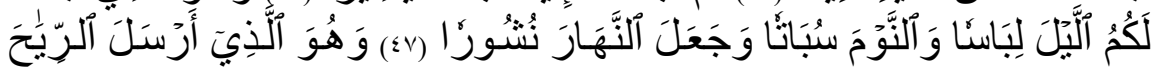

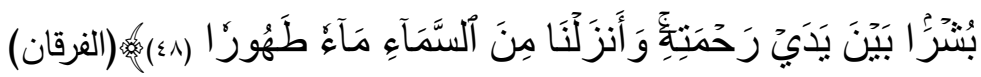

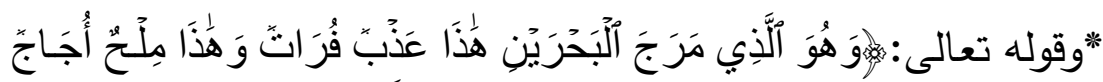

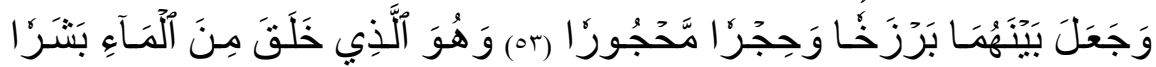

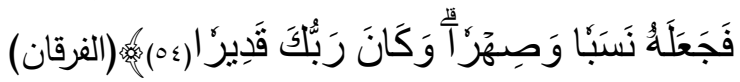
وغير ذلك من الآيات الكريمة التي تؤكد اشتقاق (تبارك) من البركة لا من

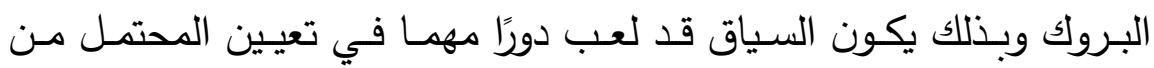

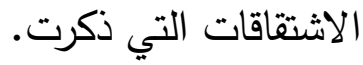

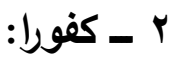

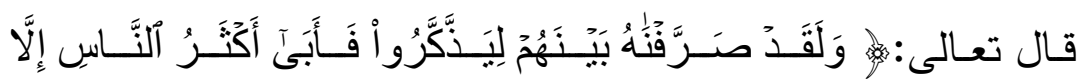

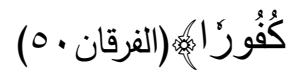

من المواضع التي اختلف في أصلها الاشتقاقي في السورة الكريمة، التي ذكرها لنا الإمام الرازي لفظة (كفورا) هل هي من (الكفران) أم من (الكفر)،

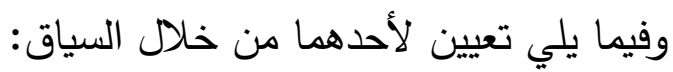

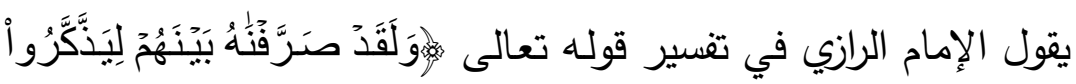

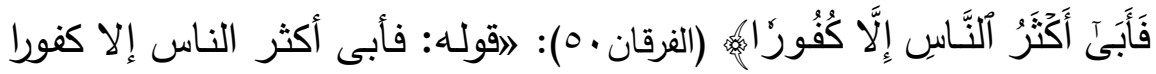

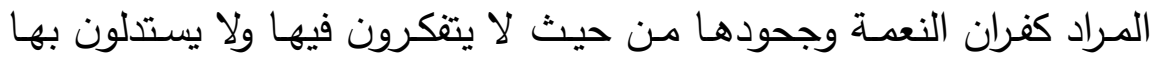
على وجود الصانع وقدرته وإحسانه، وقيل المراد من الكفور هو الكفر وذلك الكان 
الكفر إنما حصل؛ لأنهم يقولون مطرنا بنوء كذا لأن من جد كون النعم صادرة من المنعم، وأضاف شيئا من هذه النعمة إلى الأفلالك والكواكب فقد

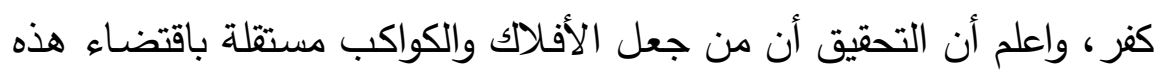

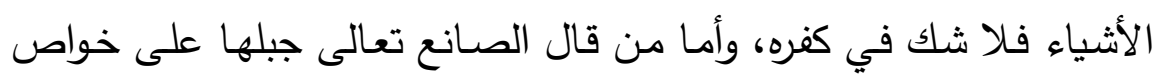

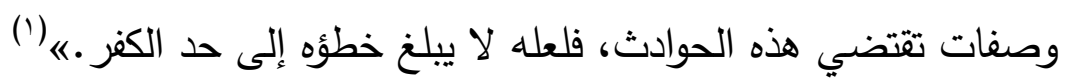
التحليل السياقي: - n - n مادة (ك ف ر) تدل في أصل الوضع على التغطية، يقول ابن فارس:

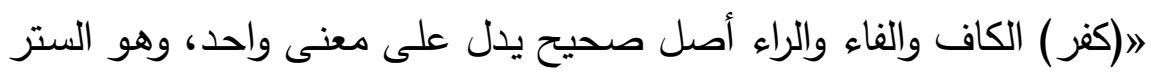

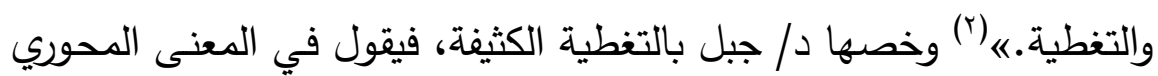

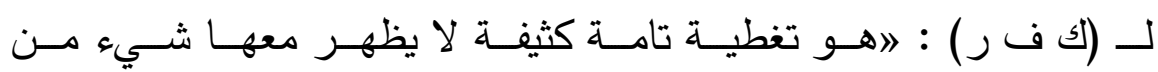

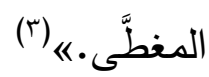

وعند البحث عن مشتقات مادة (ك ف ر) الصرفية وما هو أصل بنائها

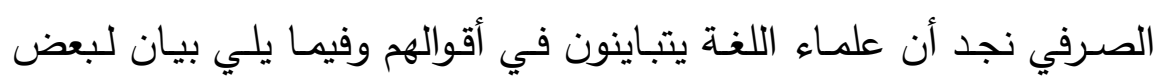
منها:

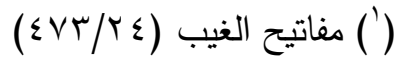

$$
\begin{aligned}
& \text { (') (") مقاييس اللغة (ك ف ر ر) }
\end{aligned}
$$
(") المعجم الاشتقاقي المؤصل لألفاظ القرآن الكريم ص19.19. 
يقول الرازي في مختاره: 》الكُفْرُ أيضا جحود النعمة وهو ضد الشكر وقد

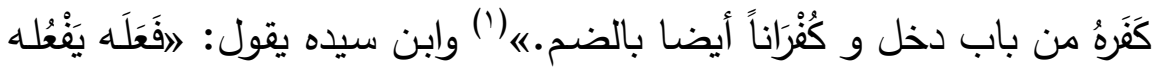

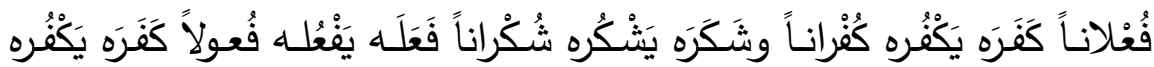

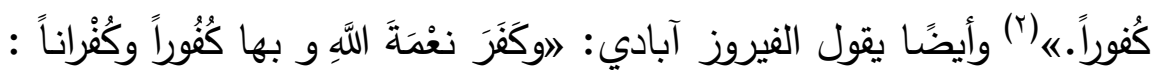
جَحَدَها وسَتَرَها.《) (َ) فهم هنا لا يفرقون بين صيغتي الكُفر والكفران والكفور في الدلالة على الجحود فهما سواء في الدلالة؛ ولكن نجد الراغب الأصفهاني يفرق مـن ناحيـة الاستعمال اللغوي بـين الصـيخ المشتقة مـن هذه المـادة، فيقول: 》الكُفْرَانُ في جحود النّعمـة أكثر استعمالا، والكُفْرُ في الدّين أكثر ، والكُفُور فيهما جميعا.ب(؛) فنرى هنا أن معظم أهل اللغة لا يفرقون بين تلك الصيغ، وربما هذا ما حمل الإمام الرازي على ذكر الاحتمالين دون الترجيح بينهما وقد يكون السر في ذلك هو الترابط القوي بين المعنيين، والأصل الواحد الذي أورده ابن فارس قد يؤكد ذلك، ولكن البحث هنا سيعمل بمعونة نظرية السياق على تعيين أحد الاحتمالين:

(') مختار الصحاح، زين الدين أبو عبد الله محمد بن أبي بكر بن عبد القادر الحنفي

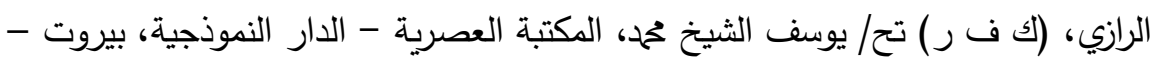

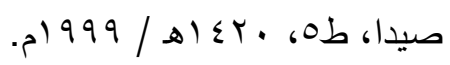

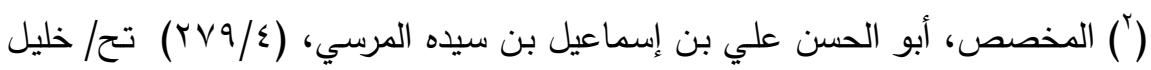

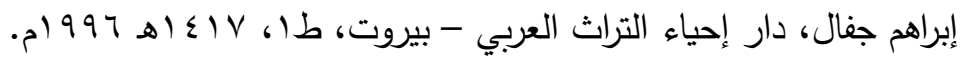

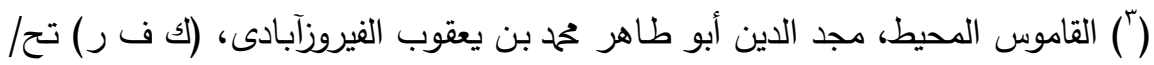
مكتب تحقيق التراث في مؤسسة الرسالة، بإشراف: حمح نعيم العرقشُوسي، مؤسسة الرسالة

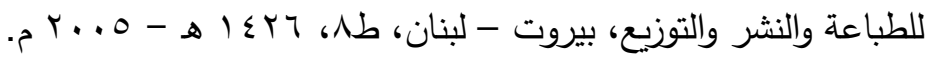

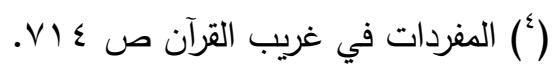


فبالنظر في كلام الإمام الرازي في تفسير الآية الكريمة نجده يورد لنا في

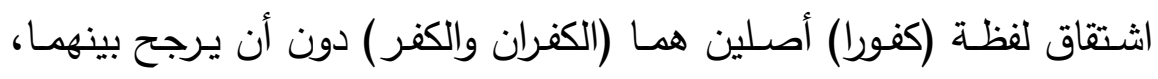

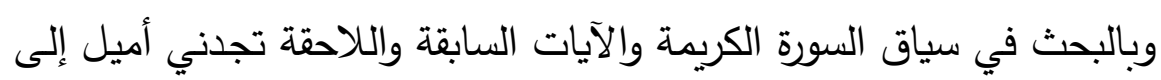
أن أصل (كفورا) هنا (الكفران) ويرشح ذلك الاشتقاق سياق المقام؛ فالسورة

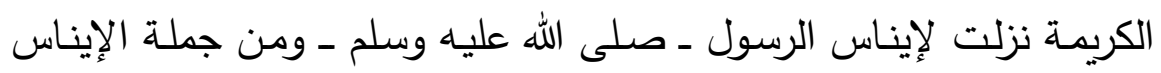

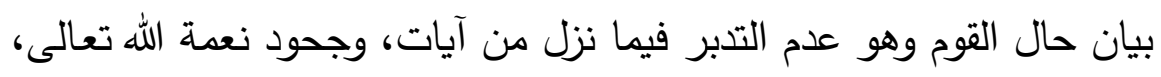

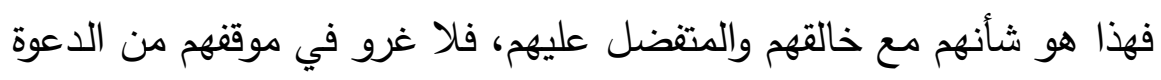

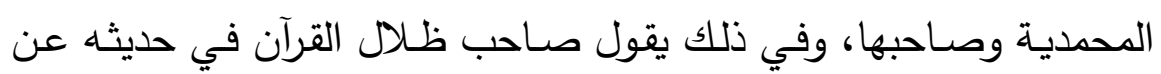

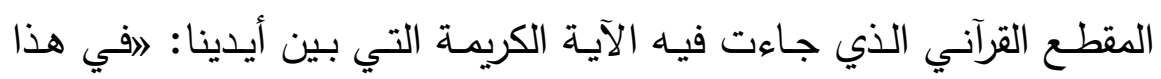

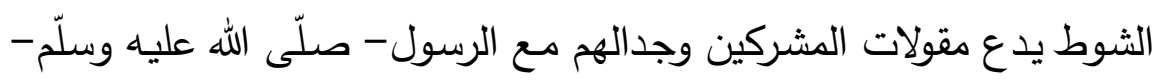

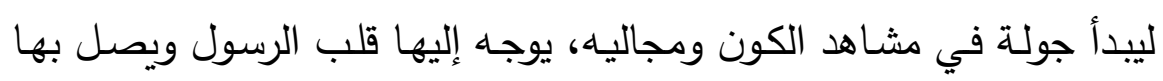
مشاعره. وهذا الاتصـال كاف وحده ليدفع خاطره عن مضايقات المشركين

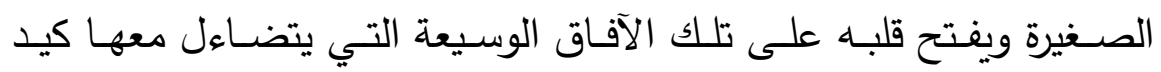
الكائدين وعداوة المجرمين.. والقرآن يوجه القلوب والعقول دائما إلى مشاهد هذا الكون ويربط بينها وبين العقول والقلوب. ويوقظ المشاعر لاستقبالها

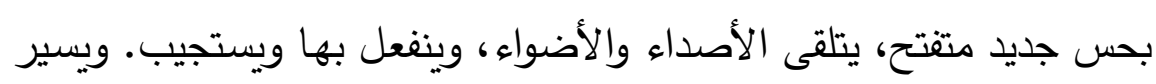

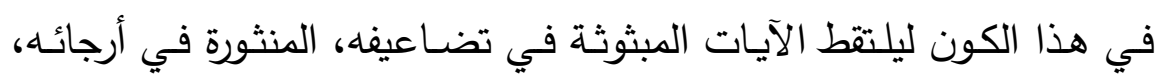

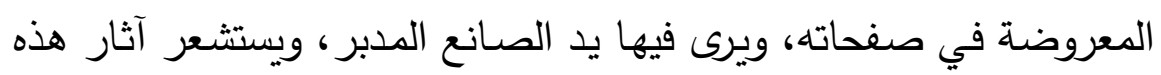

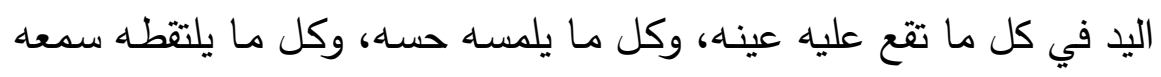
ويتخذ من هذا كله مادة للتدبر والتنكر ، والاتصال بالله، عن طريق مليق الاتصال

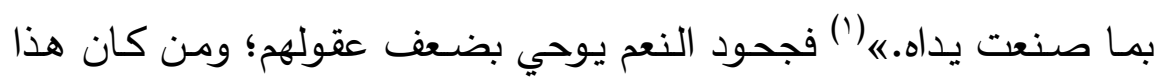


حالهم فلابد أن يصبحوا أهون من أن يكونوا سببًا في إحزان قلب المصطفى ـ صلى الله عليه وسلم - وفي ذلك احتقار لهم وتسرية لقلبه ـ صلي الله عليه

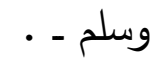
وهنـاك سـياقات مقاليـه وردت عنــ المفسرين تؤكد اشـتقاق (كفورا) مـن

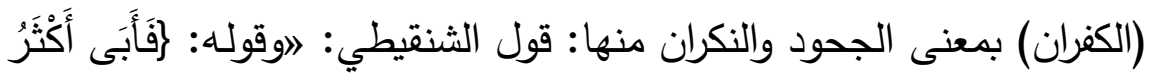

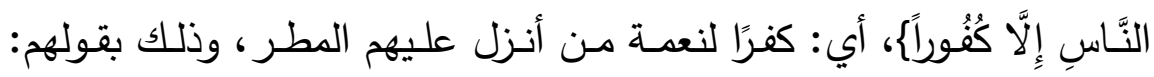
مطرنا بنوء كذا. وهذا المعنى الذي دلّت عليه هذه الآيـة الكريمة، أشار لـه

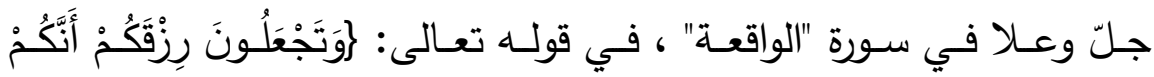

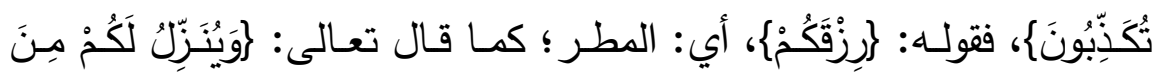

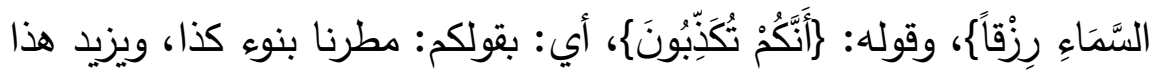
إيضاحًا الحديث الثابت في صحيح مسلم، وقد قدّمناه بسنده ومتته مستوفى، وهو أنه صلى الله عليه وسلم قال لأصـحابه يومًا على أثر سماء أصـابتهم من الليل: "اتتدرون ماذا قال ربكم"؟ قالوا: اللَّه ورسوله أعلم، قال: "قال: أصبح عبادي مؤمن بي وكافر، فأمّا من قـال: مطرنـا بفضل اللَّه ورحتـه، فذالك مؤمن بي كافر بالكوكب. وأمّا من قال: مطرنا بنوء كذا وكذا، فذاك كافر بي

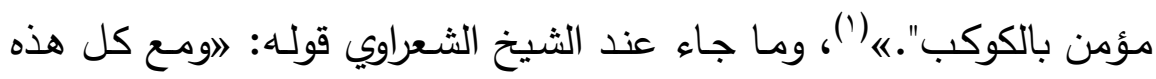

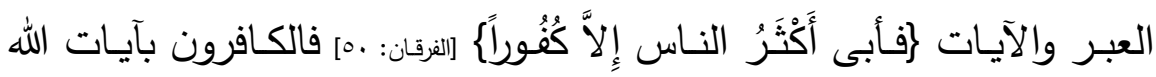

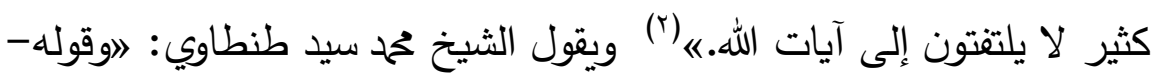

(') أضواء البيان في إيضاح القرآن بالقرآن، محمد الأمين بن محم المختار بن عبد القادر

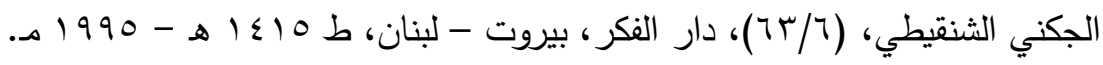

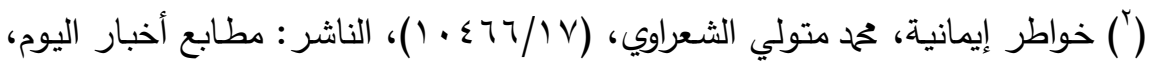




\section{مجلةقطاع كليات اللفة العريية والشعب المناظرة لها العذك [ir]}

تعالى -: فَأَبَى أَكْثَرُ النَّاسِ إِلَّ كُفُوراً بيان لموقف أكثر الناس من نعم اللهـ-

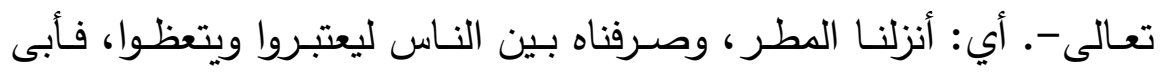

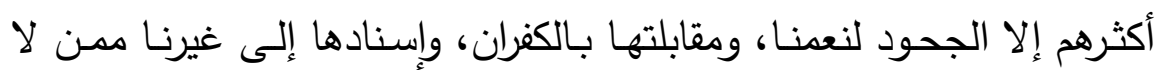
يخلقون شيئا وإنما هم عباد لنا، وخلقنا.ی) (1) مدا سبق يتضـح أن اشتقاق (كفورا) من (الكفران) هو أقوى الاحتمـالين هنا. ( - n

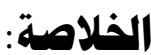

مـن المبحث السـابق يتأكد لنـا مـدى أهميـة السياق في تعيـين الأصـل

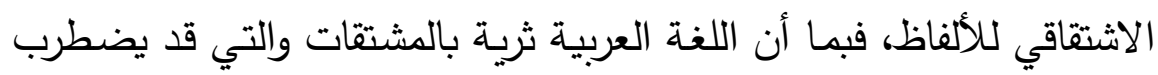
البعض في تعيينها، فلزم أن نلجأ لوسيلة تحمينا من ذلك الاضطراب فكان السياق هو الأقدر على تعيين المشتقات المرادة في المواطن المختلفة، كما حدث في لفظتي (تبارك وكفور).

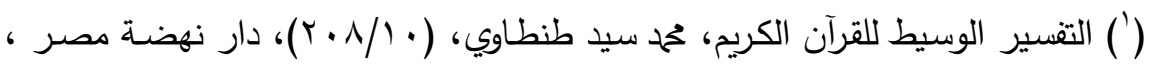

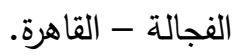




\section{المبحث الثاني}

\section{السياق القرآذي وأثره في تعيسن الزمهان}

مـن المواضــع التي تعددت فيهـا أقوال المفسـرين أثنـاء تفسير السـورة الكريمة دلالة الزمان، ولقد جمع لنا الأمام الرازي بعض هذه الأقوال، ولكي تصودي

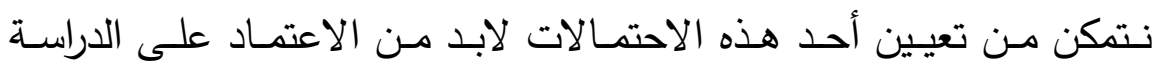
السياقية، ومنها نرجح الدلالة الأقرب؛ لأن 》السياق يحمل من القرائن اللفظية والمعنويـة والحالية ما يعين على فهم الزمن في مجال أوسع من مجرد المجال الصرفي المحدود. وهكذا يكون نظام الزمن جزمًا من النظام الصرفي، وأمـا الزمن السياقي فإنـه جزء مـن الظـواهر الموقعيـة السياقية؛ لأن دلاكـة الفعـل على زمنٍ ما تتوقف على موقعه وعلى قرينته في السياق.بـ(') ودن الآراء التي اختلف فيها العلماء وأوردها لنا الرازي في تفسيره مسألة خلق النار، وعذاب الكافرين هل هو في الدنيا؟ أم في الآخرة؟ أم فيهما معا؟ ولكي نقف على تلك المسألة ونوضح الأقرب للصواب فيها لابد من التحليل السياقي حتى يوقفنا على الأرجح من تلك الآراء، كالآتي:

$$
\text { - (أعتدنا) - ( }
$$

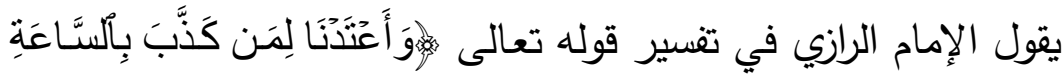
سَعِيرًا لهُم(الفرقان (1): اوقوله: أعتدنا إخبار عن فعل وقع في الماضي، فدلت الآية على أن دار العقاب مخلوقة قال الجبائي يحتمل وأعتدنا النار في الدنيا وبها نعذب الكفار والفساق في قبورهم، ويحتمل نـار الآخرة، ويكون معنى

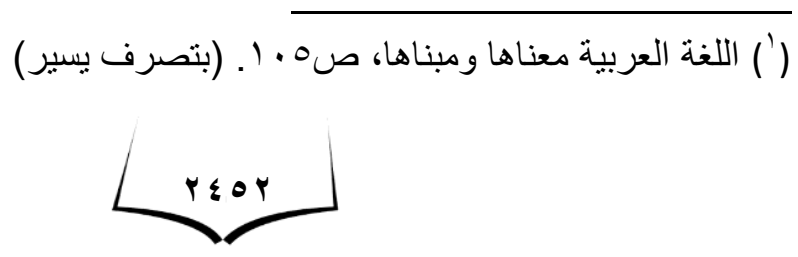


وأعتدنا أي سنعدها لهم كقوله:

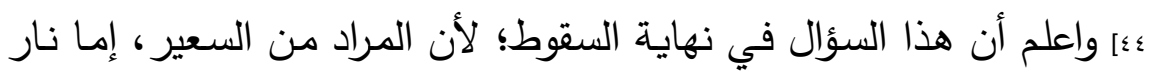

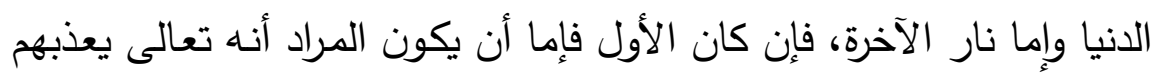

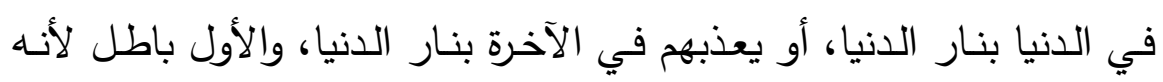

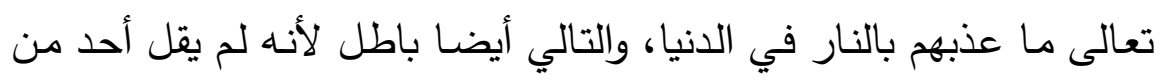

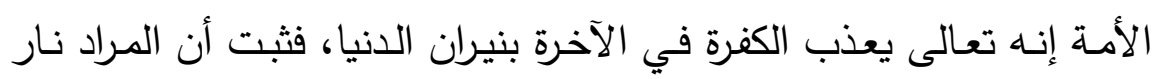

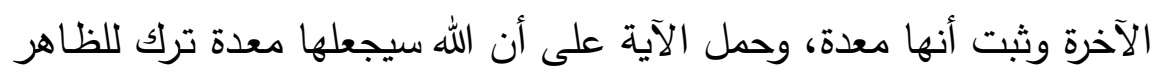

من غير دليل.ب( (1)

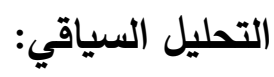

الفعل (أعتدنا) مأخوذ من (عتد) وهي تدل على التقيئة والحضور يقول

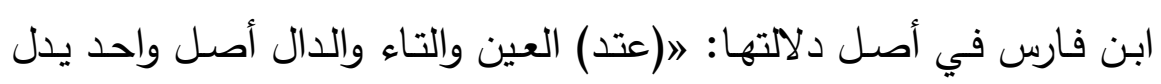

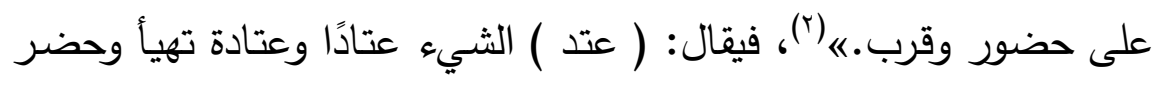

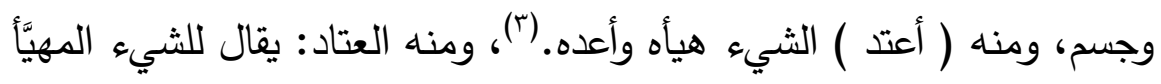

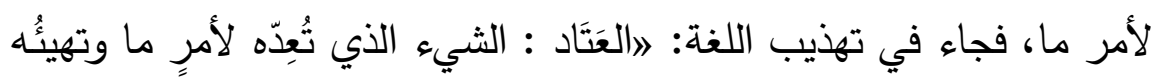

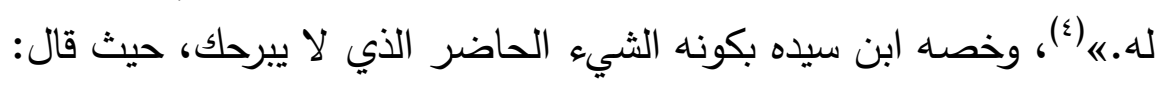

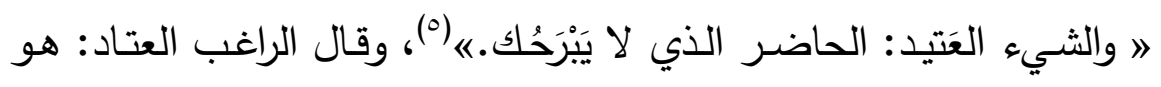

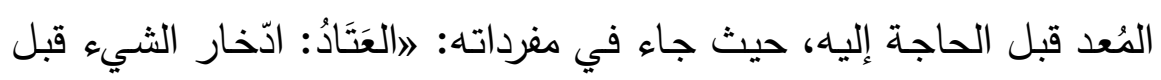

$$
\begin{aligned}
& \text { (') مفاتيح الغيب (ع ( }
\end{aligned}
$$

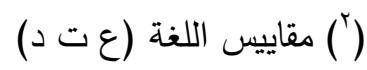

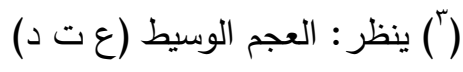

$$
\begin{aligned}
& \text { () (أ) تهذيب اللغة (ع ت د د) }
\end{aligned}
$$

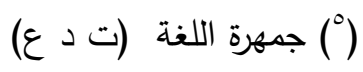


الحاجـة إليـه كالإعـداد.ب(') تلـك آراء أهـل اللغــة في أصـل المـادة ومعناهـا المحوري، وهذه الدلالات تبين لنا المراد منها وهو الثيء المعد مسبقًا وتلك الك الدلالة الزمانية قصدها الإمام الرازي في نصده السابق: فبالنظر في كلام الفخر الرازي نجده أورد لنا رأيين في مسألة خلق دار العقـاب، والعـذاب للكـافرين، ورجـح أحدهما وهـو أن المـراد مـن الآيـة نـار الآخرة، وأنها معدة، ويرشـح ذلك بالإضـافة للدلالة اللغويـة التي ذكرهـا أهل اللغة عن معناها المحوري السابق الإشارة إليه عدة سياقات لغويـة وردت عن المفسرين تؤكد أن العذاب سيكون في الآخرة بالرغم من كون النار معدة من

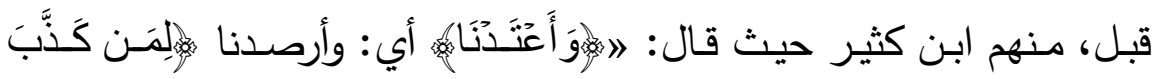

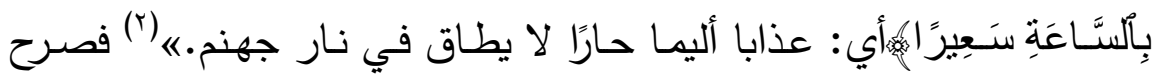
بكـون العـذاب يكـون في جهنم، وتلك في الآخـرة، وتلك الدلالــة الزمانيـة

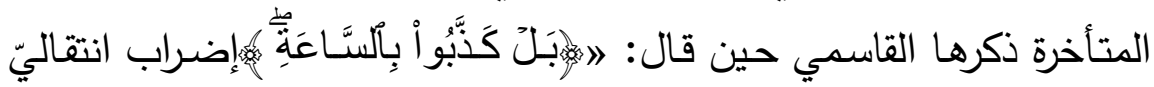
عن تـوبيخهم بحكايـة جنـايتهم السـابقة، وانتقـال منـه إلى تـوبيخهم بحكايـة جنايتهم الأخرى، للتخلص إلى بيان مـا لهم في الآخرة بسببها، من فنون

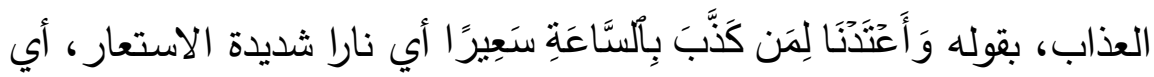
التوقد والالتهاب.ی)(ץ) وتلك الدلالتة جاءت عند معظم علمـاء التفسير فقال

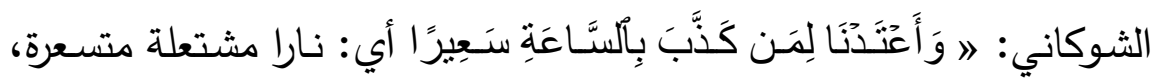

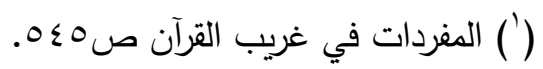

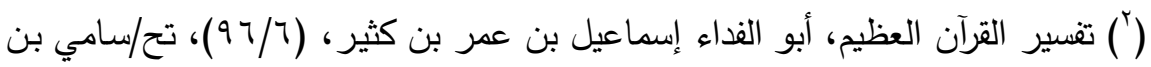

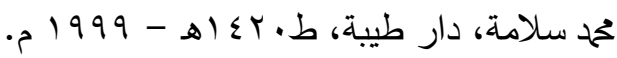

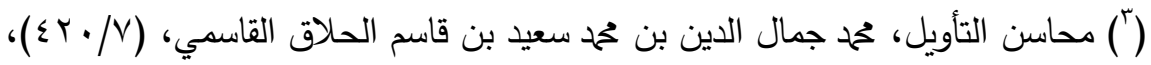

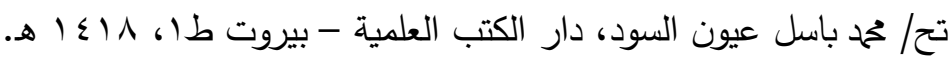


والجملة في محل نصب على الحال، أي: بل كذبوا بالساعة، والحسال أنـا

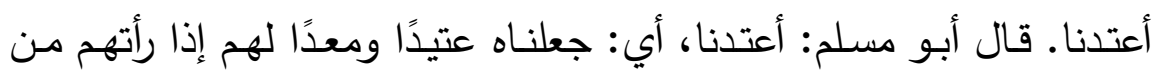

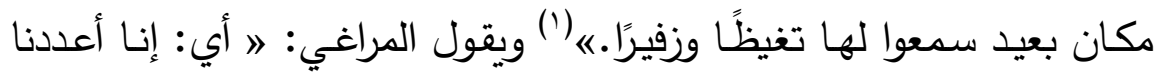

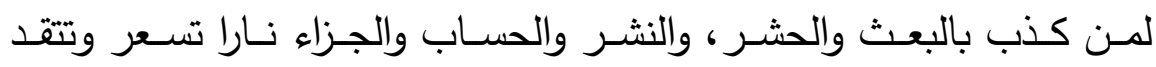

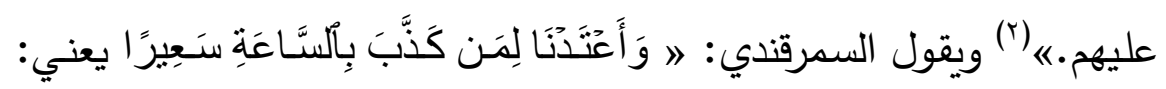

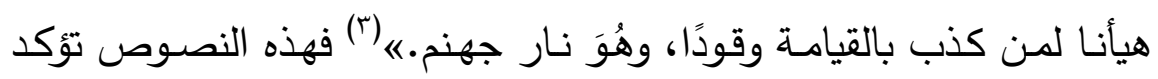

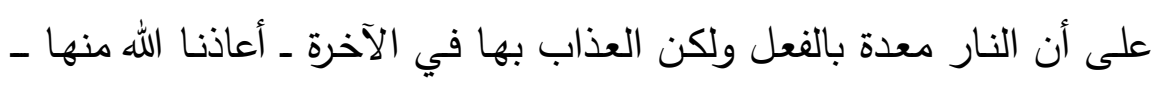

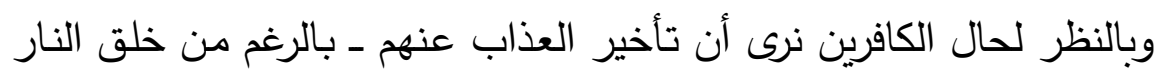

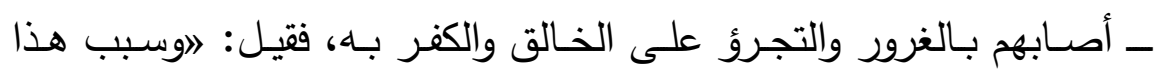

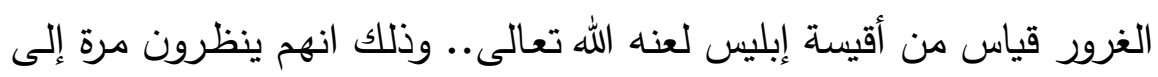

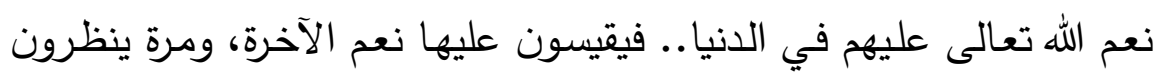

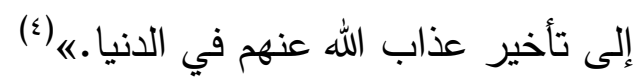
وبذلك يتضح لنا قوة الرأي القائل بتأخير العذاب للكفار للآخرة، بالرغم

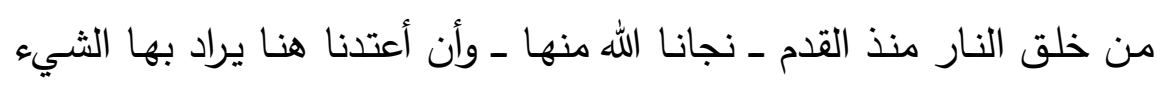

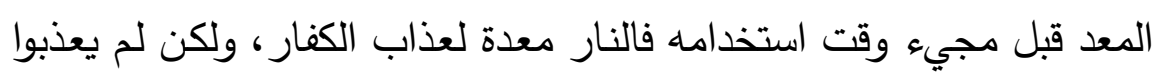

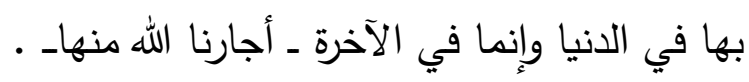

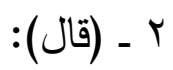

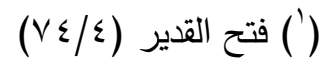

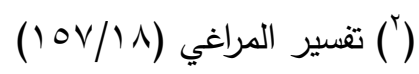

$$
\begin{aligned}
& \text { (") (") بحر العلوم (T)/ (") }
\end{aligned}
$$

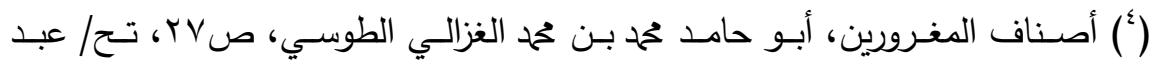
اللطيف عاشور ، مكتبة القرآن، القاهرة - مصر . 
من المواضـع التي أورد لنـا الإمام الرازي اختلاف المفسرين في دلالتها

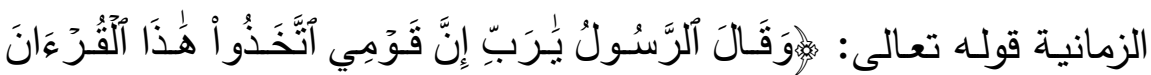

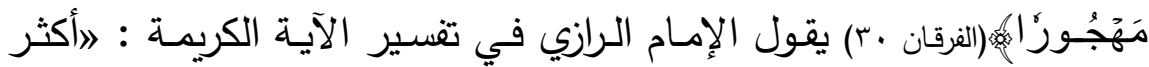
المفسرين أنه قول واقع من الرسول ـ صلى الله عليه وسلم - وقال أبو مسلم

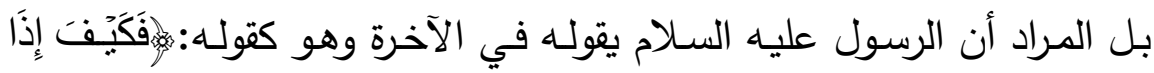

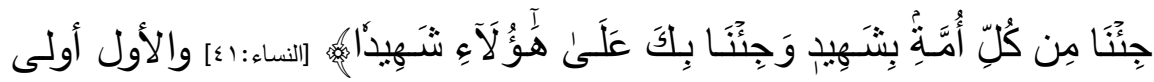

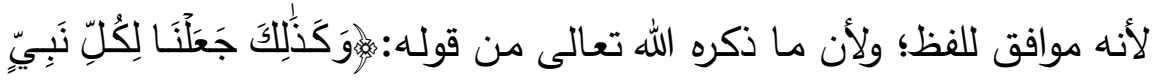

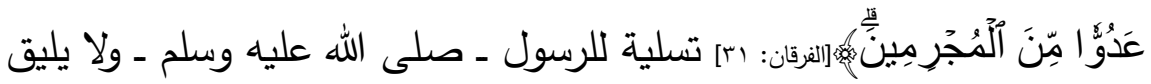
إلا إذا كان وقع ذلك القول منه.ی) (') التحليل السياقي: - n الفعل (قال) مـأخوذ مـن (ق و ل) وهي تدور حول النطق، يقول ابن فارس فيها:»(قول) القاف والواو واللام أصل واحد صحيح يقل كلمه، وهو

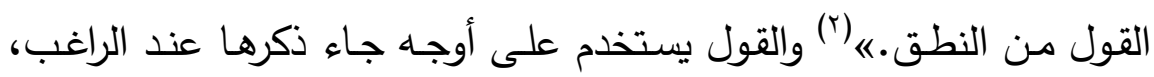
فقال: والقَقْلُ يستعمل على أوجها: أظهرها أن يكون للمركّب من الحروف المبرز بالنّطق، مفردا كان أو جملة. الثاني: يقال للمتصوّر في النّقس قبل الإبراز باللفظ: قَوْلّ، فيقال: في نفسي

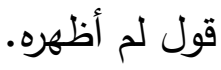
الثالث: للاعتقاد نحو فلان يقول بقول أبي حنيفة.

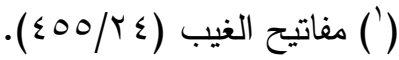

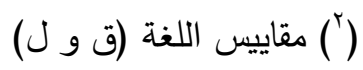


الرابع: يقال للدّلالة على الثيء .

الخامس: يقال للعناية الصادقة بالثيء، كقولك: فلان يَقُولُ بكذا.

السـادس: يستعمله المنطقيّون دون غيرهم في معنى الحدّ، فيقولـون: قَوْلّ الجوهر كذا، وقَوْلُ العرض كذا، أي: حدّهما.

(السابع: في الإلهام. (') - (1)

وما يعنينا هنا هو زمان القول الوارد في الآية الكريمة، لا ماهيته ولا فيما

يستخدم:

ففي نص الإمـام الرازي في تفسير الآيـة الكريمـة يذكر لنا الاحتمالات

الواردة في زمـان قول النبي ـ صلى الله عليه وسلم ـ لمضـون هذه الآيـة الكريمة، هل هي في الدنيا أو في الآخرة، ولقد عين لنا الإمام الرازي ورجح كونه واقعًا منه ـ صلى الله عليه وسلم ـ في الدنيا، وترى الباحثة الاتفاق معه في كونه قولًا واقعًا من النبي ـ صلي الله عليه وسلم ـ في الدنيا. ويرشح ذلك السياق اللغوي الدال على أن هذا القول وقع منـه ـ صلى الله عليه وسلم - في الدنيا وهو مجيء لفظة (قومي) في الآية وإجماع المفسرين على أن المقصـود بهـا هنـا هـ أهل قريش مـن المشـركين والكفـار (r)، فهنـا يقصد فئـة بعينها وقومًا بعينهم فهو يقصدهم في الخطـاب وكانت رسـالته تخص قوم قري في بداية الدعوة إلى أن انتشرت وذاعت في الأفاق وأخذت

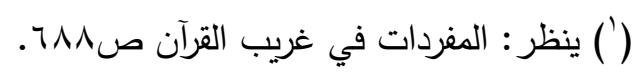

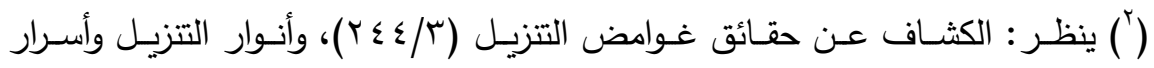

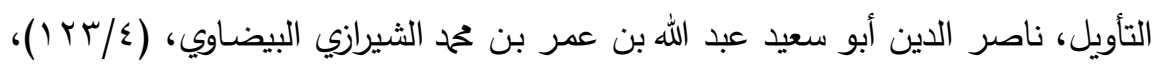

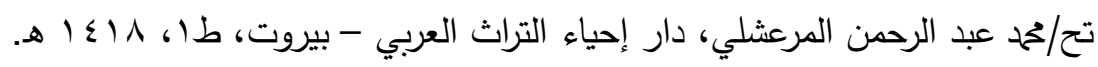


في الشيوع إلى أن أصبحت رسالة للخلق كافة إلى أن يرث الله الأرض ومن عليها كما قال عز وجل ( إن الدين عند الله الإسـلام) فلو كانت مقولتة في الأخرة فلن يقصد بها قريشًا فقط بل الخلق جميعا، فكان دلالتة لفظة (قومي) على قريش فقط مرشحًا أن المقولة كانت في الدنيا. وهنالك سياق لغوي ثانٍ وهو قوله تعالى في الآية التي جاءت بعد هذه

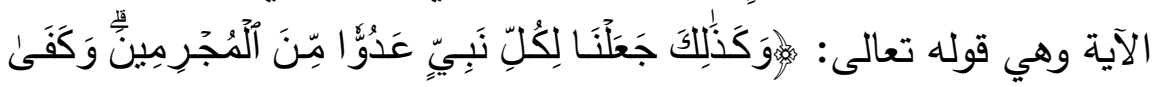

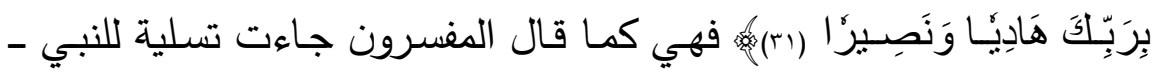
صلي الله عليه وسلم - ووعدا بالنصر لله عليهم فيقول أبو العباس المهدي

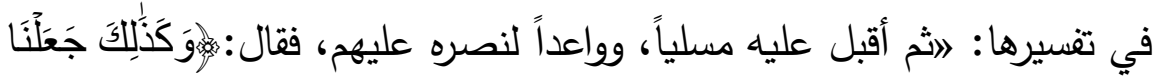

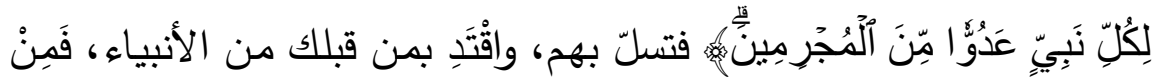
هنـا سَـاروا. أي: كمـا جعلنـا للك أعداء مـن المشـركين يقولـون مـا يقولـون، ويفعلون مـا يفعلون من الأباطيل، جعلنـا لكل نبي من الأنبياء، الذين هـ

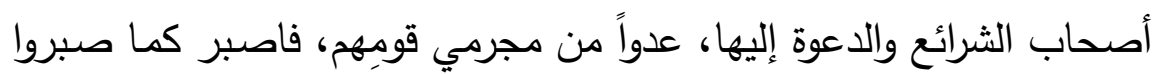
فإن الله ناصرك كما نصرهم.« (') وأيضًا يرشح ذلك السياق المقامي: وهو شفقة الرسول الكريم على أمته، فلا يتصور وقوع هذا القول منه في الأخرة وهو شفيع لأمته وقد ادخر دعوته لأمته في الأخرة للثفاعة لهم، فكيف يقيم عليهم حجة توجب عذابهم حتى في وإن كان الخالق عالمًا بكل شيء فمثل هذا القول يقع منـه ــ صلى الله عليه

(') البحر الدديد في تفسير القرآن المجيد، أبو العباس أحمد بن محمد بن المهدي بن

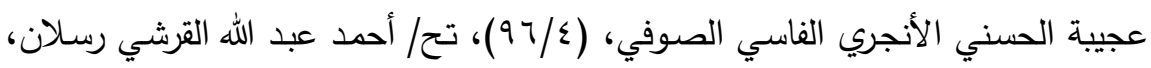

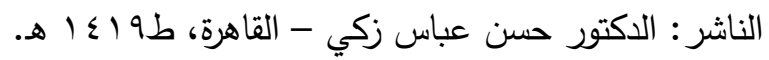


وسلم - في الدنيا من باب الالتجاء للخالق وطلب العون منه في أن يشرح

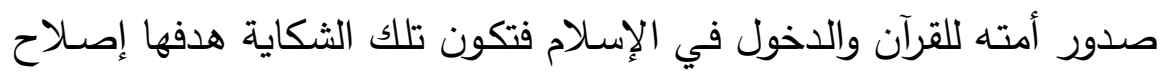

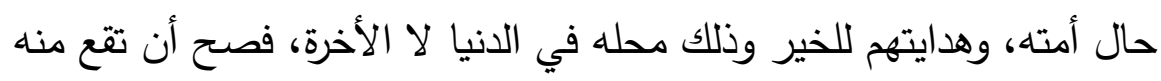
في الدنيا، رحمة بنا وشفقة علينا. مما سبق يتضح لنا أن هذا القول واقع من النبي ـ صلى الله عليه وسلم -

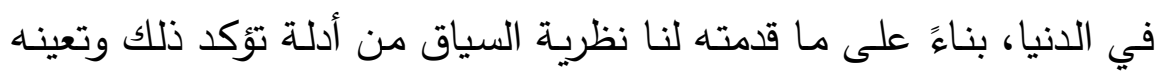

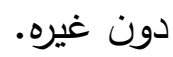

\section{الاستنتاج: - (الاج}

من هذا المبحث يبرز لنا دور السياق البالغ الأهمية في تعيين المراد

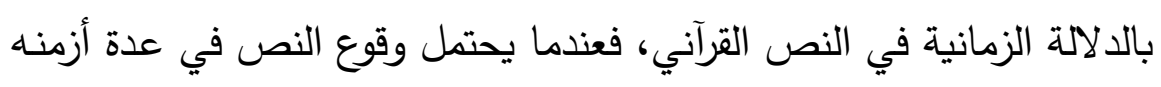

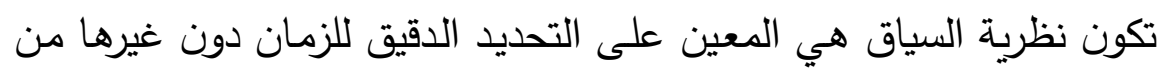

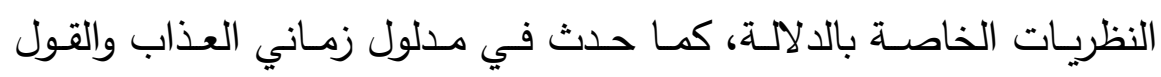

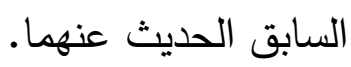


النيياق القراًأنيه وأثره فهي تعيين المعنص عند الفخر الرازيه

\section{المبحث الثالث}

\section{السياق القرآني وأثره في تعيين دلالة الصيغة}

من الاختلافات التي وقعت بين المفسرين وأوردها لنا الإمام الرازي في تفسيره للسـورة الكريمـة اختلافهم في المـراد بدلالـة الصـيغة، أو كمـا يسميه البعض قيام صيغة مقام أخرى، والمراد بالصيغة في الاصطلاح لاهي الهيئة

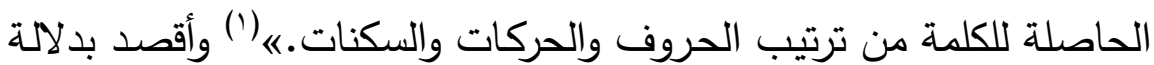
الصيغة هنا المعنى اللغوي لها الذي يتتاسب مع سياق الآيات الكريمة. وذلك جاء في دلالة صيغة (ظهيرا) الواردة في السورة الكريمة : : (ظهيرا) -

اختلف المفسرون في المراد بصـيغة (فعيل) التي جاءت عليها لفظـة (ظهيرا) هل هي بمعنى (مفاعل) أو بمعنى اسم الجمع فتكون بمعنى (فعيل) لا تخرج عنها أو بمعنى (مفعول) ، وذلك الاختلاف أورده لنا الإمام الرازي في تفسيره، وسـنرى بمعونـة السـياق أي الـلالات تلتناسـب والسـورة الكريمـة وتتفق مع مجريات الأحداث بها:

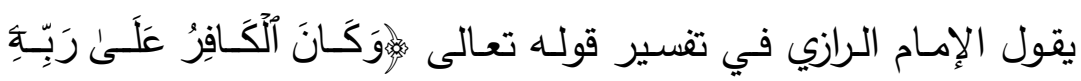

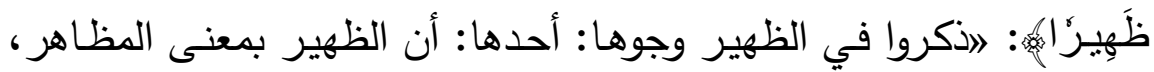
كالمعين بمعنى المعـاون، وفعيل بمعنى مفاعل غير غريـب، والمعنى أن وهئ

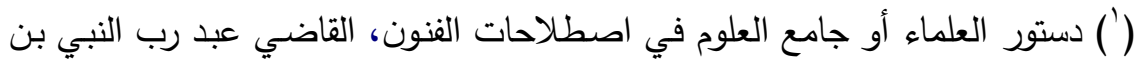

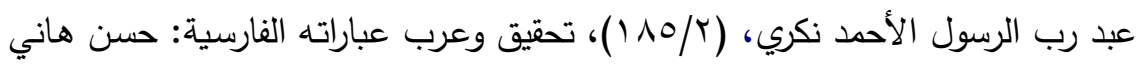

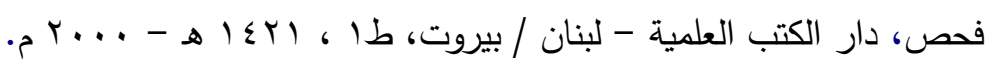


الكافر يظاهر الثنيطان على ربه بالعداوة. فإن قيل كيف يصح في الكافر أن

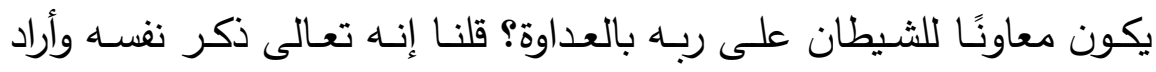

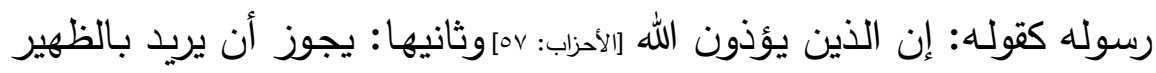

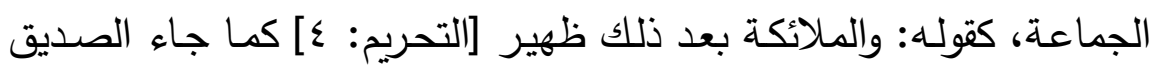

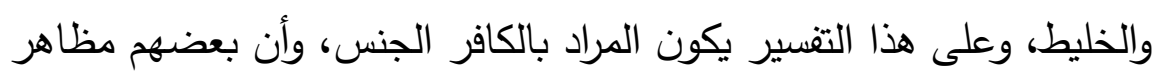

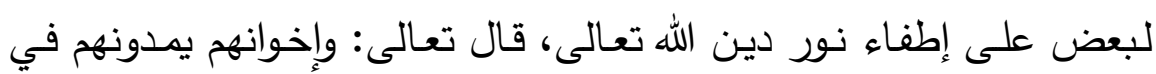

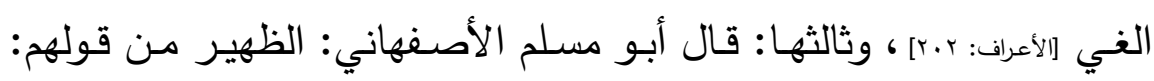

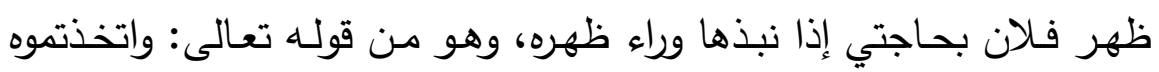

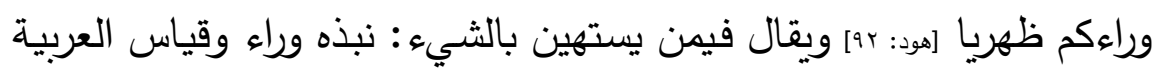

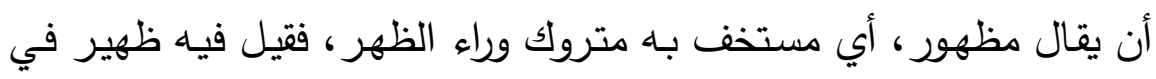

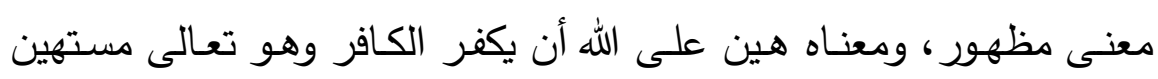
(1) بكفره. (1)

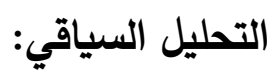

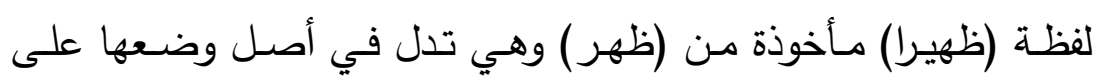
البروز والقوة، يقول ابن فارس في أصلها الاشتقاقي: پالظاء والهاء والراء

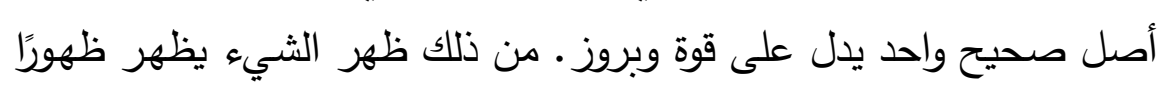

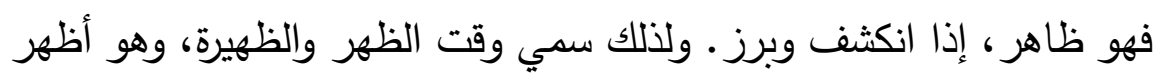

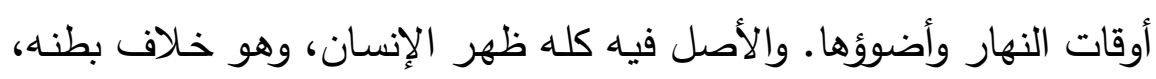

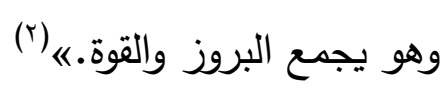

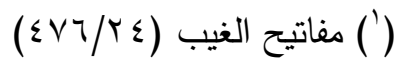

$$
\begin{aligned}
& \text { (') مقاييس اللغة (ظ هـ ر) }
\end{aligned}
$$


وقال الراغب الأصفهاني الأصل في ظهر الثيء أن يحصل على ظهر الأرض لا باطنها ثم عمم في كل ما هو مبصر وظاهر ، فيقول: "اوظََهَرَ

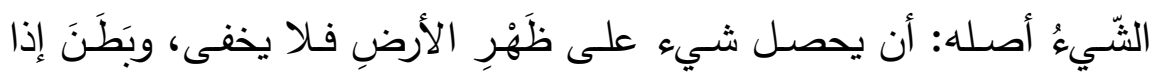

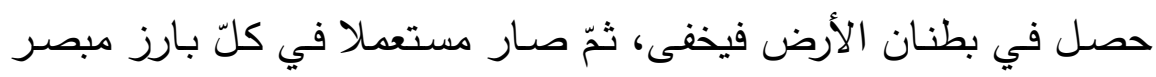

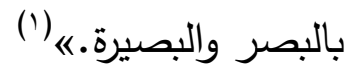

ويقول د/ جبل في معنى (ظهر) المحوري بعدما ذكر أنها تدل في أصل

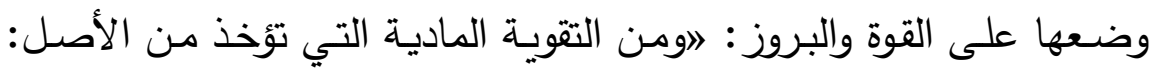

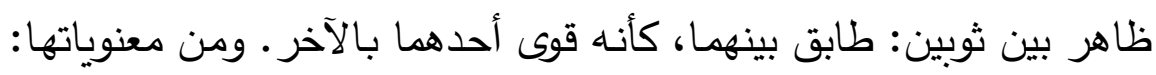

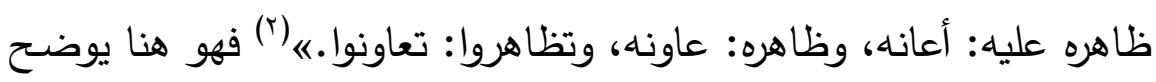

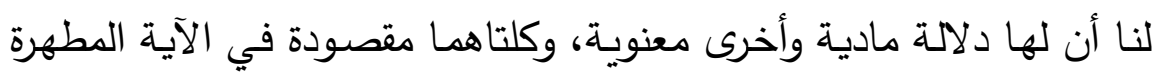
التي بين أيدينا هنا، وذلك ما سنستوضحه من خلال التحليل السياقي التالي: في نص الإمام الرازي نراه أورد لنا ثلاثة أراء في المراد بصيغة (ظهير ) التي على وزن فعيل: فإما بمعنى مظاهر فتكون فعيل بمعنى مفاعل، وإما فراهـ

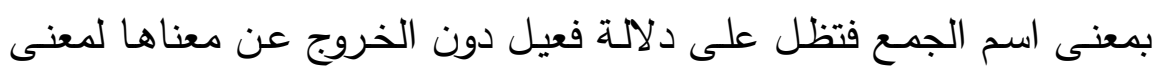
غيرها من الصيخ، وإما بمعنى مظهور فتكون فعيل بمعنى مفعول. وبالنظر في سياق الآيـة الكريمة وسياق السورة ترى أن المعنيين الأول

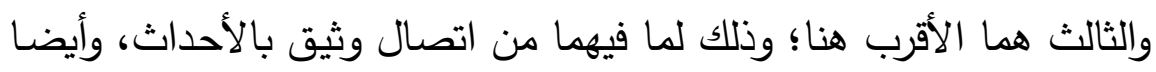

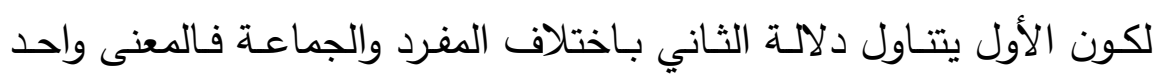

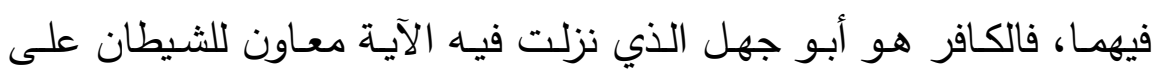

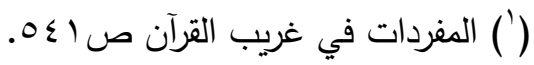

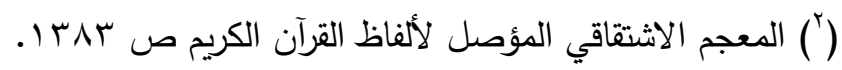


معصية الله والمتمثلة في محاربة رسوله الكريم، وهذا ما يفعله الجماعة؛ لذا ترى كثيرًا من المفسرين جعل معناهما معنى واحدًا، وأيضـا على المعنى الثالث يكون كفر العبد هينًا على الخالق ـ عز وجل ــ، فالخالق مستهين بالكافر وبكفره، ويُرشَح هذين المعنيين سياقات مقاليه وردت عند المفسرين منها:

مـا ذكره المساوردي، فيقول: الفيـه وجهان: أحدهما: عونـاً، مـأخوذ مـن

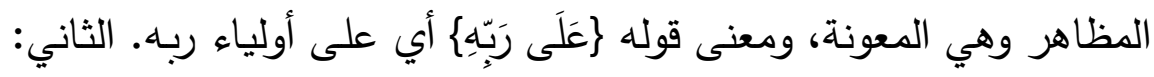

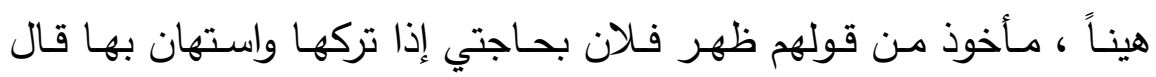

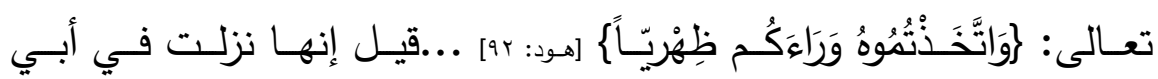

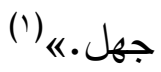

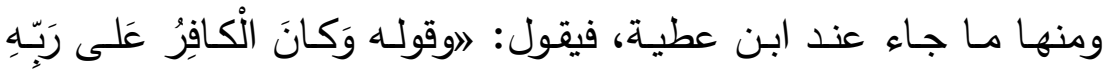
ظََِيراً فيه تأويلان: أحدهما أن (الظهير) المعين فتكون الآية بمعنى توبيخهم على ذلك من أن الكفار يعينون على ربهم غيرهم من الكفرة والثيطان بأن يطيعوه ويظـاهروه، وهذا هو تأويل مجاهد والحسن وابن زيد، والثاني ذكره الطبري(؟) أن يكون (الظهير) فعيلا، من قولك ظهرت الثهيء إذا طرحته وراء ظهرك واتخذتهه ظهريـا، فيكون معنى الآيـة على هذا التأويـل احتقار

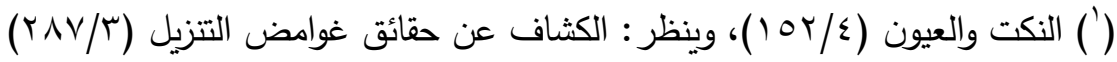

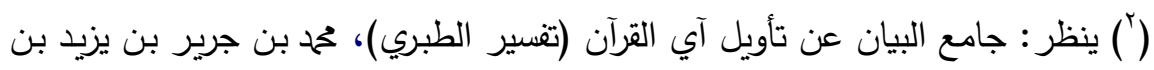

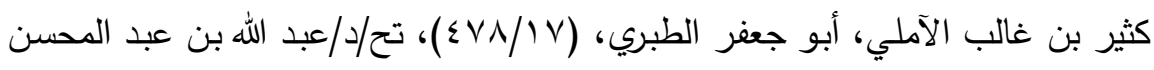

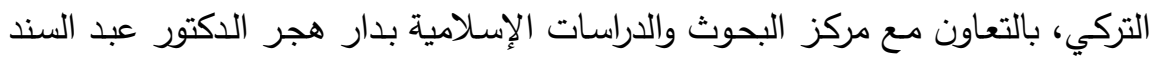

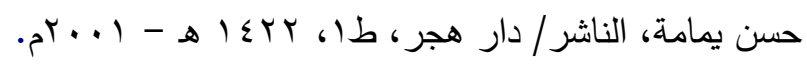


الكفرة، والْكافِرُ في هذه الآية اسم الجنس وقال ابن عباس بل هو معين أراد

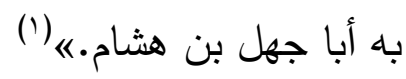
فنزول الآية في أبي جهل يرشح كونـه هو المقصود هنا، وليس جماعة الكفار ، وذلك سياق مقامي يرشح المعنى الأول. والمعنى الثالث: وهو احتقار الكفر، وكونه أمرًا هينًا في ملك الخالق ـ عز وجل ـ لا يساوي جناح بعوضـه، يرشحه سياق مقالي جاء في السنة النبويـة المطهرة يحمل المعنى ذاته ورد في سنن ابن ماجه، فجاء فيه: حَدَّنًَا عَبُُْ اللَّهِ

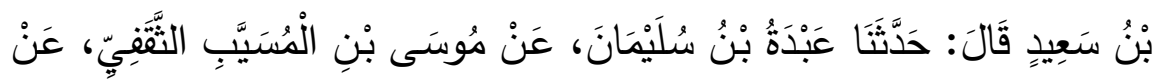

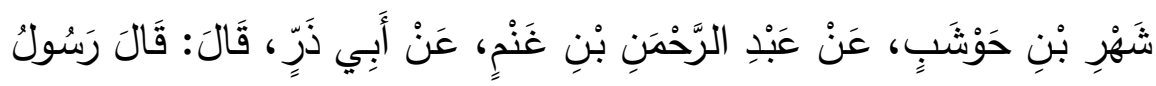

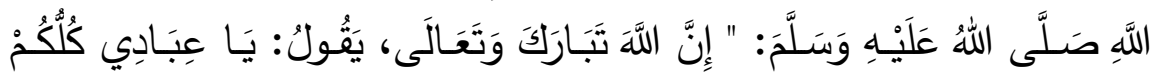

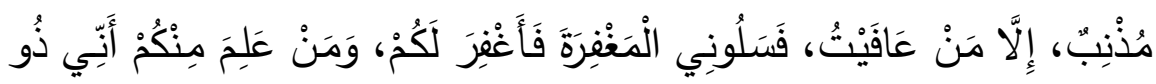

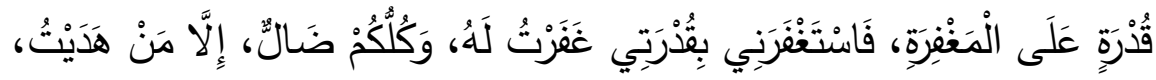

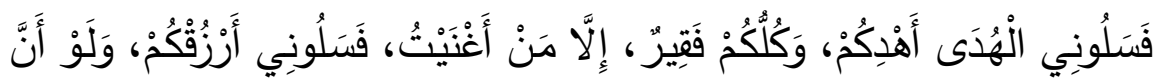

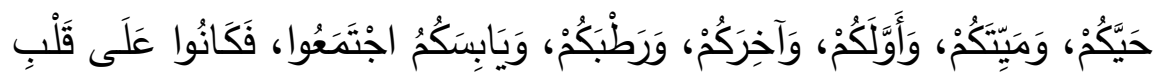

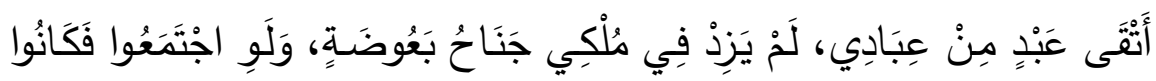

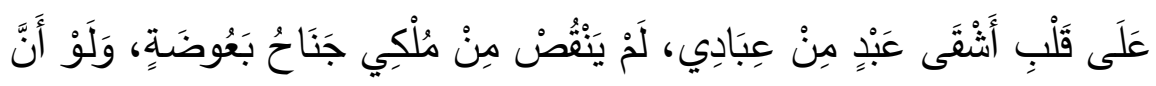

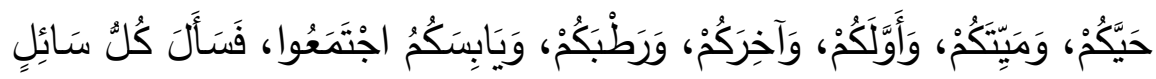

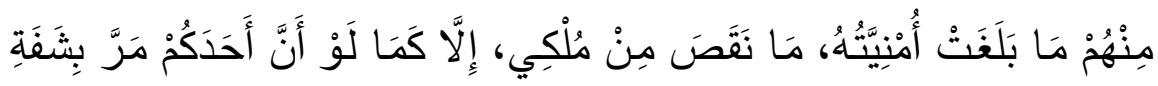

(') الدحرر الوجيز في تفسير الكتاب العزيز (10/1) 


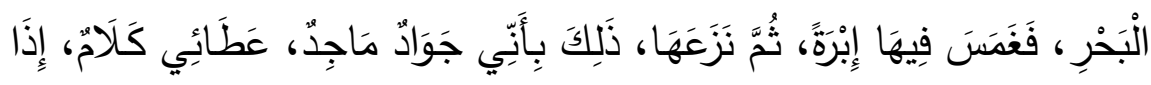

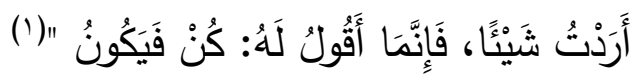

ومما يرشح هذين المعنيين مـا جاء في كتب النحاة من مجيء فعيل بمعنى مفعول ومفاعل يقول ابن عقيل: اينوب فعيل عن مفعول في الدلالة

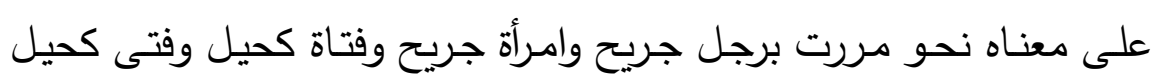

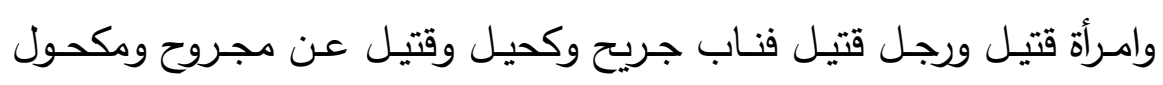

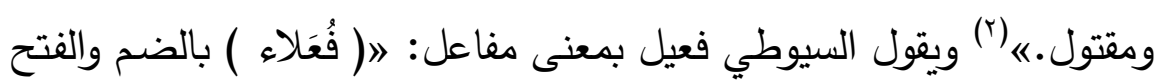
ويطرد جمعا ( لفعيل وصف ذكر عاقل بمعنى فاعل مفعل أو مفاعل )

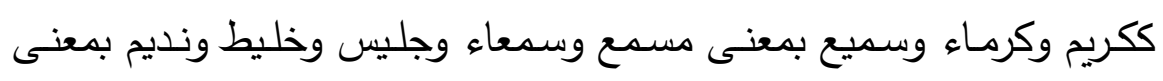

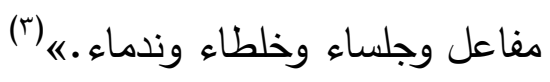

الاستنتاج:

مما سبق يتبين أن المعنيين الأول وهو: أن ظهير بمعنى مظاهر أي:

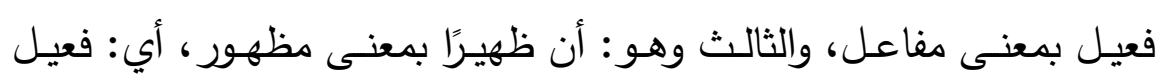

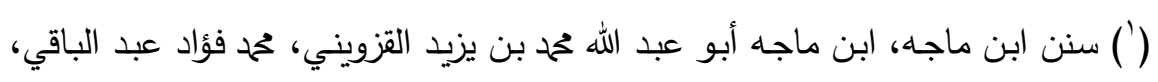

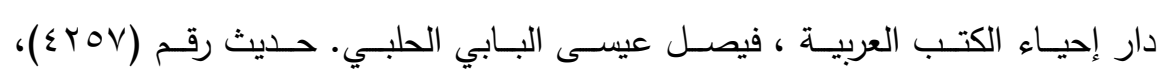
() (I \& Y T/ T)

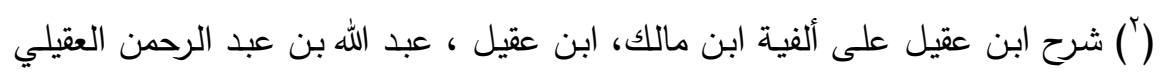

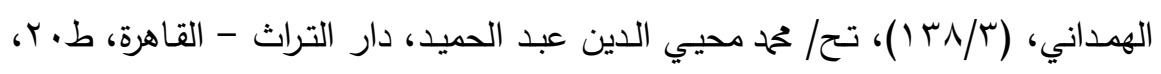

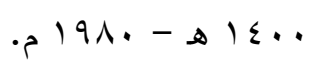

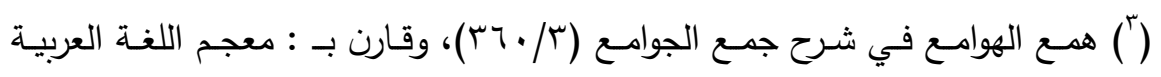

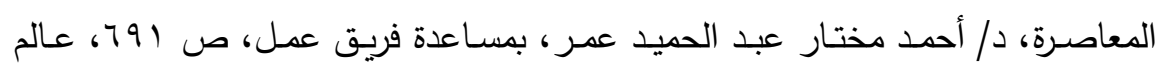

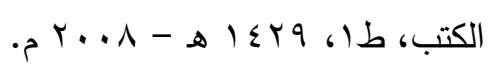


النيياق القراًأنيه وأثره فهي تعيين المعنص عند الفخر الرازيه

بمعنى مفعـول هــا الأنسـب لدلالـة الآيـة الكريمـة هنـا، وأكد ذلك السـياق ووضحه، وبذلك تظهر قيمة السياق البالغة الأهمية في تعيين المحتمل من معاني الصيخ التي تحتمل الاختلاف في المراد منها. प 


\section{المبحث الرابع}

\section{السياق القرآني وأثره في تعيين المتكلم}

من القائل؟ سؤال يُكرر في الآيـات القرآنية واختلف فيه المفسرون، وتبعًا لاختلاف المتكلم لابد مـن اختلاف المعنى المـراد، ولا سبيل لتعيين

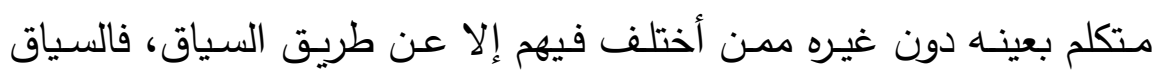
بمثابة المصباح الذي يضـيء لنـا الدروب التي تعسج بالدلالات المتداخلة، فبنـوره نهتدي لأنسـب الـدلالات المتفقـة مـع النصـوص، ومـن هذه الدروب المتكلم؛ فاختلاف المتكلم لابد من أن يترتب عليه اختلاف الدلالة المرادة من

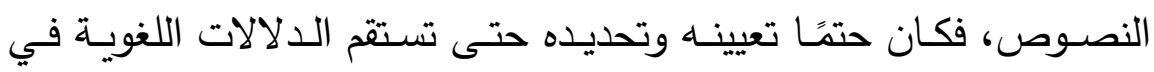
النصوص.

وهذا السؤال جاء ذكره في سورة الفرقان وأثـار إليه الإمـام الرازي في تفسيره في مواضـع عدة، منها اختلافهم في المتكلم في قوله تعالى :

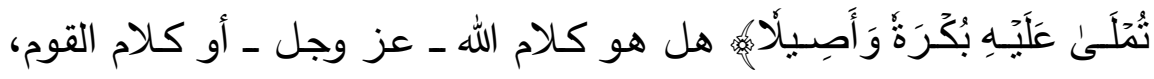

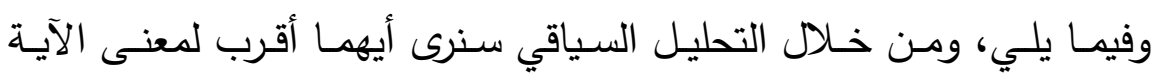

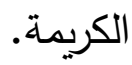

$$
\text { : } 1
$$

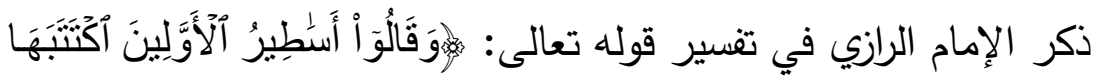

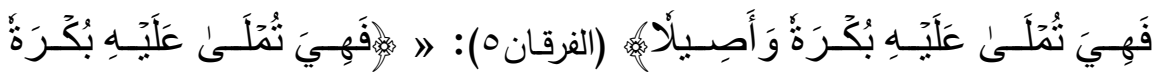

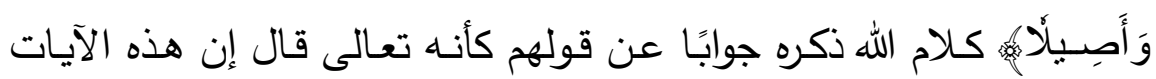
تملى عليه بالوحي حالًا بعد حال، فكيف ينسب إلى أنـه أساطير الأولين،

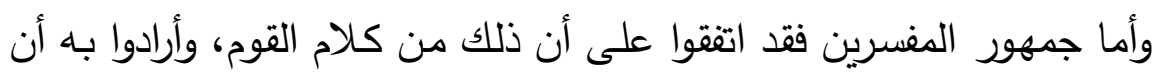


أهل الكتاب أملوا عليه في هذه الأوقات هذه الأشياء ولا شك أن هذا القول أقرب لوجوه: أحدها: شدة تعلق هذا الكـلام بمـا قبله، فكأنهم قالوا اكتتب هده أساطير الأولين فهي تملى عليه، وثانيها: أن هذا هو المراد بقولهم: وأعانهـ عليه قوم آخرون وثالثها: أنه تعالى أجاب بعد ذلك عن كلامهم بقوله: قل

أنزله الذي يعلم السر •«(') التحليل السياقي:

مـن النص السـابق نـرى أن الإمـام الـرازي أورد اختلاف المفسـرين في المتكلم ولم يكتف بذلك بل رجح أحدهما وأورد مرشحات لرأيه هذا من خلال نظريـة السـياق، وذلك عنـدما نظـر للسـياق اللغـوي الجزئسي السـابق للآيـة واللاحق لها:

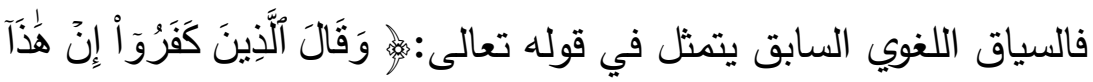

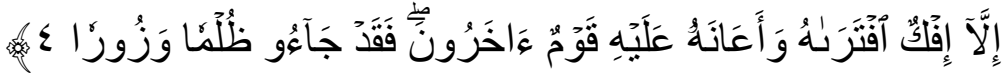

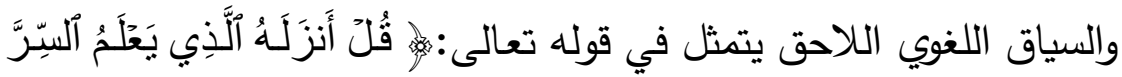

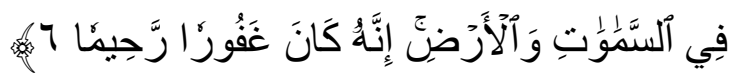
وتتقق الدراسة مع الإمام الرازي في هذا القول، وبالإضـافة لما ذكره من مرشـحات مـن خـلال السـياق اللغوي الجزئي في السـورة الكريمـة ستضـيف لإنـ الدراسـة بعض المرشحات الأخرى المعتمدة على السياقات اللغويـة الأخرى فيما يأتي:

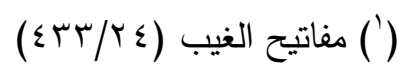


كلمة (تملى) مأخوذة من (م ل ل) ومنها اشتق الإملاء بمعنى الكتابة،

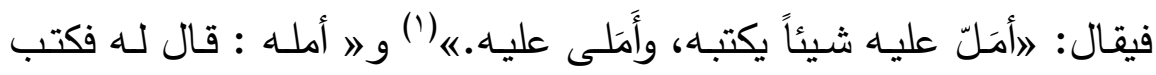

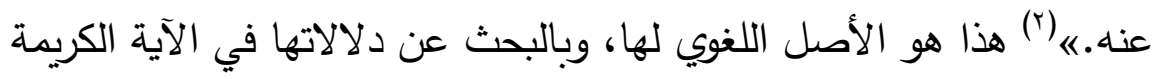

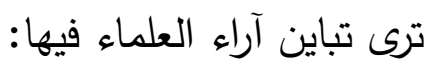
فالعيني يقول فيها: اوفسر : (تملى عليه) بقوله: (تقرأ عليه).با (r) فهي بمعنى القراءة وهذا يناسب السياق القرآني.

وهذا د/ جبل يري أن (تملى) مأخوذة من (م ل و ) والمعنى المحوري لها لهائ

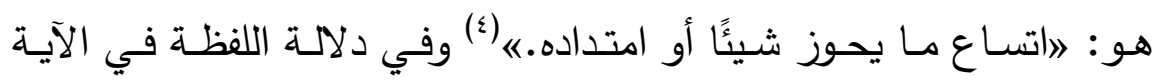

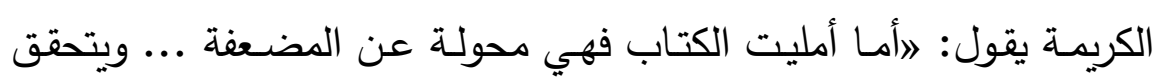

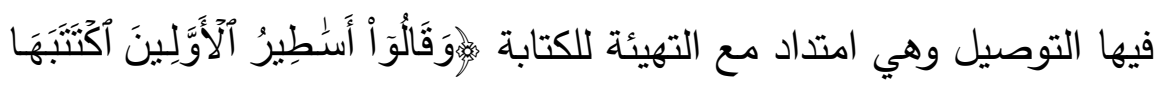

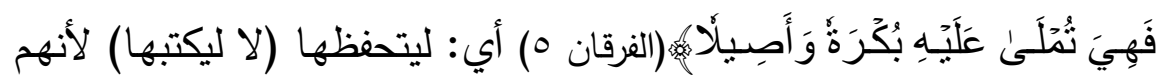

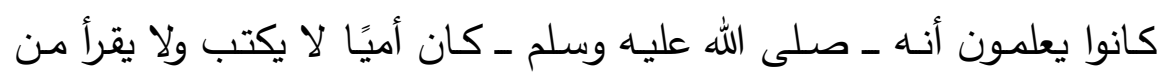

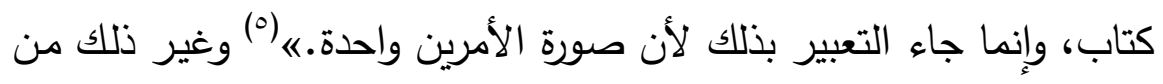

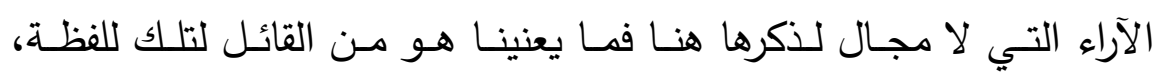
وللإجابة على هذا السؤال سنذكر بعض السياقات اللغوية الموضحة له له منها:

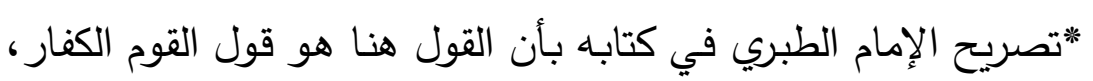

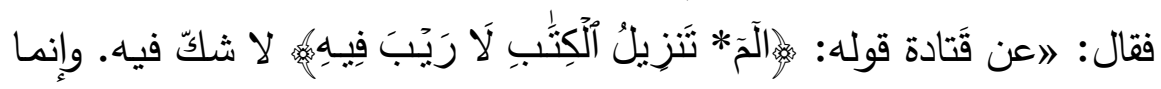

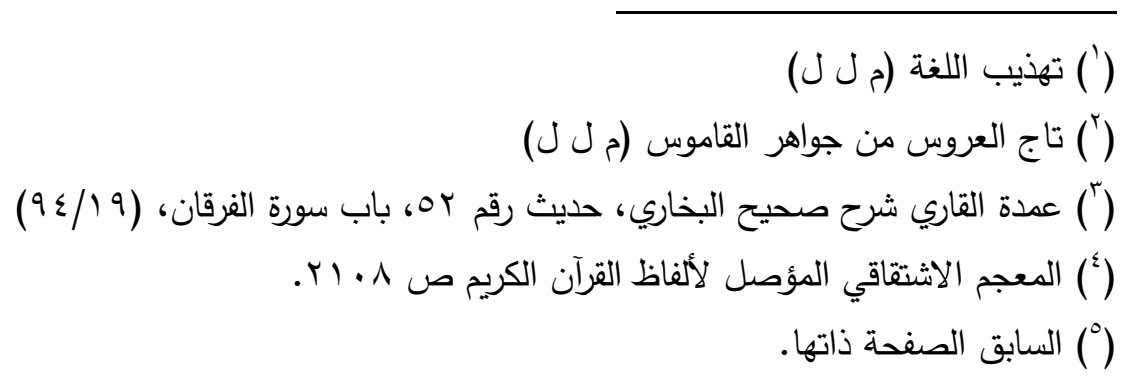


معنى الكلام: أن هذا القرآن الذي أُنزل على محمد لا شكّ فيه أنه من عند الله، وليس بشعر ولا سجع كاهن، ولا هو مما تخرّصه حمحد ـ صلى الله عليه وسلم

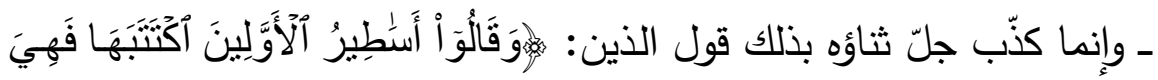

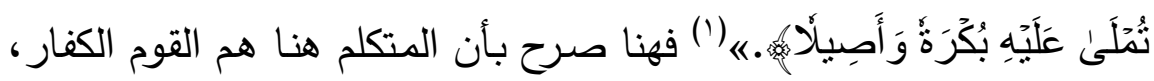
ليس الخالق تعالى - جلَّ في علاه ـ وتتزه عن ذلك وتعالى علوًا كبيرًا. "وأيضًا ما صرح به الإمام الثوكاني من أن الآية الكريمة جاءت حكاية لقول منكري النبـوة فقـال: الولمـا فرغ مـن بيـان التوحيد، وتزيـف مـذاهب المشركين، شرع في ذكر شبه منكري النبوة. فالشبهة الأولى: ما حكاه عنهم بقوله: وقال الذين كفروا إن هذا إلا إفك... ثم ذكر الثبهة الثانيـة فقال:

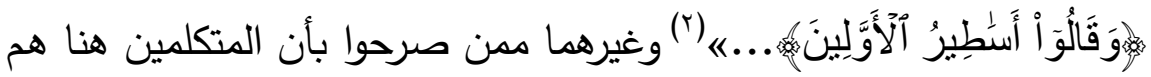
كفار القوم. (r) *وهناك سياق لغوي ثالث يؤكد ويرشح أن القائلين هنا هم الذين كفروا : وهو أن الواو في (وقالوا) عاطفة(؛) فبذلك تكون هذه الآية هي أيضًا من قول

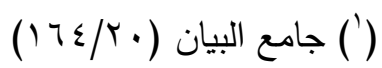

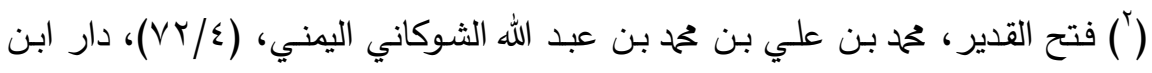

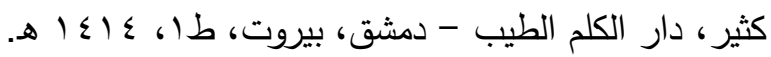

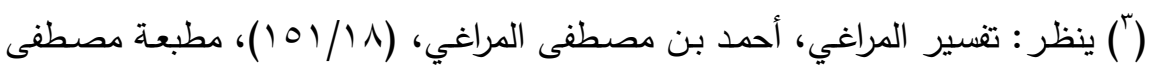

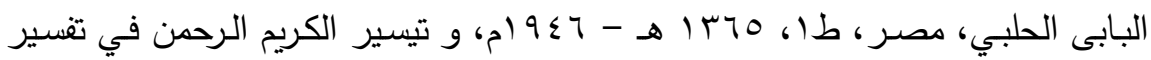

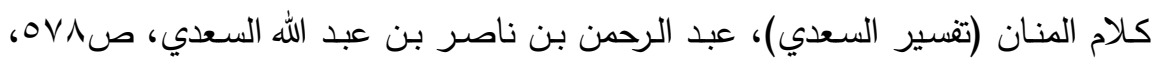

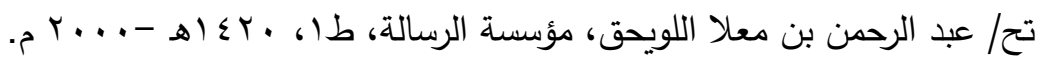

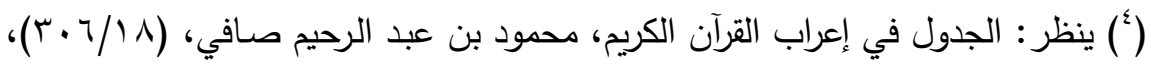

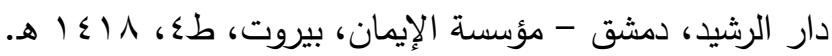


الكافرين كسـابقتها، وهذا يفسر قول الرازي أن الآيـة شديدة التعلق بالسـابقة لها.

مما سبق يتضح أن السياقات اللغويـة تضامت لتؤكد لنا أن المتكلم هنا هو القوم لا الخالق - عز وجل - . - - (حجرًا محجورا)

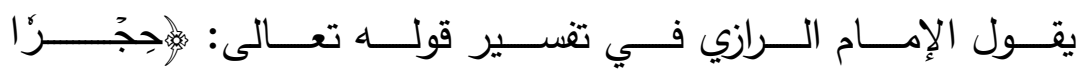

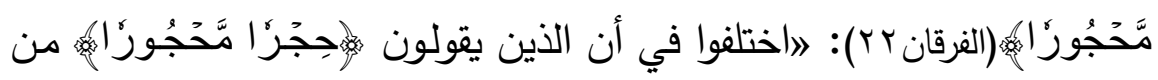
هم؟ على ثلاثة أقوال: القول الأول: أنهم هم الكفار وذلك لأنهم كانوا يطلبون نزول الملائكة ويقترحونه، ثم إذا رأوهم عند الموت ويوم القيامة كرهوا لقاءهم وفزعوا منهح لأنهم لا يلقونهم إلا بما يكرهون، فقالوا عند رؤيتهم مـا كانوا يقولونه عند لقاء العدو ونزول الثدة. القول الثاني: أن القائلين هم الملائكة ومعناه حراما محرما عليكم الغفران والجنة والبشرى، أي جعل الله ذلك حراما عليكم، ثـم اختلفوا على هذا القول فقـال بعضهم إن الكفـار إذا خرجوا مـن قبورهم، قالت الحفظة لهم حجرا محجورا، وقال الكلبي الملائكة على أبواب الجنة يبشرون المؤمنين بالجنة ويقولون للمشركين حجرا محجورا، وقال عطية إذا كان يوم القيامـة يلقى الملائكة المؤمنين بالبشرى فإذا رأى الكفار ذلك لك قـالوا لهم بشـرونا فيقولـون حجـرا محجـورا القـول الثالث: وهـو قـول القفـال والواحدي وروي عن الحسن أن الكفـار يوم القيامـة إذا شـاهدوا مـا يخافونـهـ فيتعوذون منه ويقولون حجرا محجورا، فتقول الملائكة لا يعاذ من شر هذا

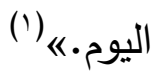

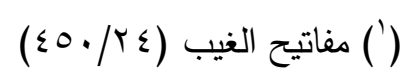


الحجر بمعنى المنع يقول ابن فارس فيها: ״(حجر) الحاء والجيم والراء أصل واحد مطرد، وهو المنع والإحاطة على الثيء. فالحجر حجر الإنسان، وقد تكسر حاؤه ويقال حجر الحاكم على السفيه حجرا؛ وذلك منعه إياه من التصرف في ماله. والعقل يسمى حجرا لأنه يمنع من إتيان ما لا ينبغي.« (') وقد تأتي لتخصيص دلالة الحرام كما قال ابن سيده: اوالحِجْر والحَجْر والحُجْر والمَحْجَر : كل ذلك الحرام.«(؟) وفي الجاهلية كانوا يستخدمون لتلك العبارة للدلالة على حرمة الدم حيث جاء فيها: اوالحِجْرُ والحُجْرُ لغتان وهو الحَرام ، قال : وكان الرجل في الجاهلية يلقى الرجل يخافُه في الشهر الحرام فيقول : حِجْراً مَحْجُوراً أي حراٌُ مُحَرَّم عليك في هذا الثـهر فـلا يَنْدَاهُ منـهـ شـر ، قـال : فـإذا كـان يـوم القيامـة رَأَى المشـركون الملائكـة فقـالوا : حِجْراً

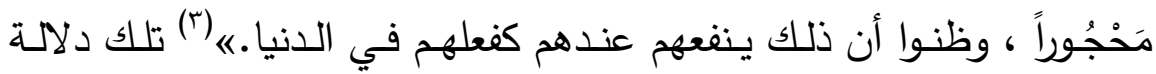
(حجرًا محجورا) اللغوية ل وبالنظر في تفسير الآية الكريمة الوارد فيها تلك العبارة، وخاصة فيما جاء عند الإمام الرازي نراه يسوق لنا أقوال المفسرين في القائل لتلك الجملة التي كانت معهودة عند العرب قديمًا، وبعرض ذلك نجد اغلب أقوال المفسرين

$$
\begin{aligned}
& \text { (') مقاييس اللغة (ح ج ر) }
\end{aligned}
$$

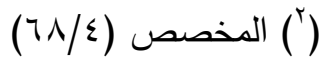

$$
\begin{aligned}
& \text { (") تهذيب اللغة (ح ج ر ) }
\end{aligned}
$$


تؤيد الرأي القائل بأن تلك مقولة الملائكة وهناك سياقات لغويـة وردت عند المفسرين يؤكد دلالتها على كون الملائكة هم المتكلمون هنا:

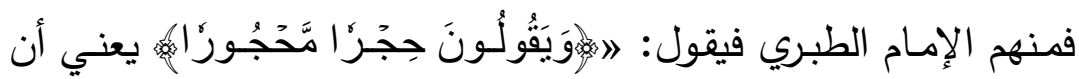

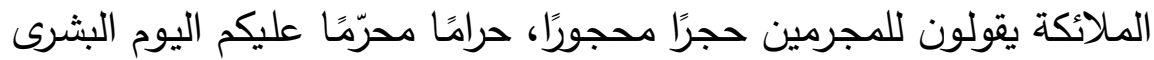

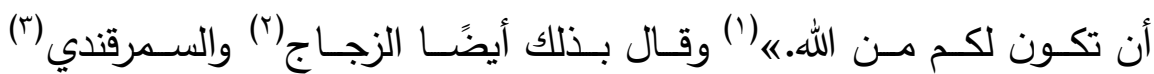
والواحدي(؛) وابن عطية(ن) والقرطبي (؟) وغيرهم.

وسياق الحال هنا يناسب كونها مقولة الملائكة فالحال حال إثابة للمؤمن وعقاب للعاصي ومن جملة العقاب تقريعهم من قبل الملائكة بمنع البشرى عنهم جزاءً على كفرهم فحرمت البشرى عليهم، وأيضًا الطبيعة البشرية تأنف من الاعتراف باستحقاق العقاب على ما ارتكبت من ذنب فتبرأ من الخطأ سيمة البشر حتى وإن ارتكبوه فلا يعقل أن يحكموا على أنفسه بالحرمان كما ذهب إليه المفسرون في تفسيرها. مما سبق يتبين لنا أن القائلين هنا هم الملائكة، وأكد ذلك السياق القرآني للآية الكريمة.

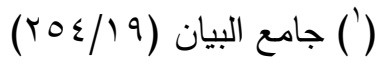

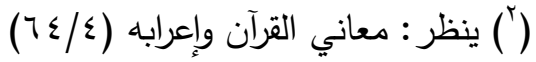

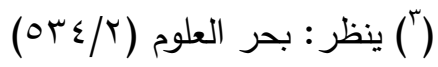

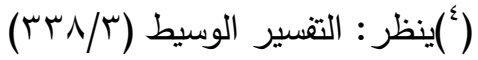

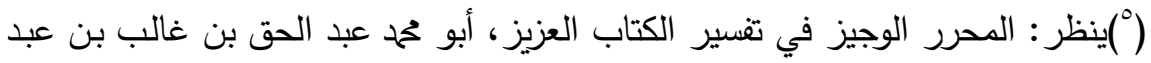

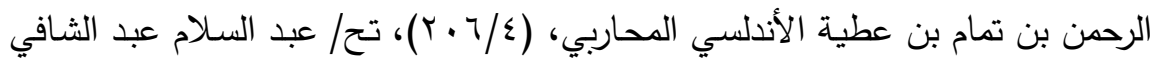

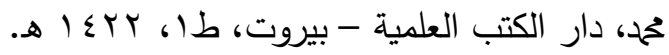

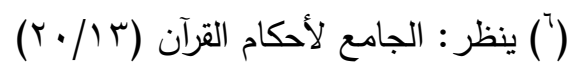




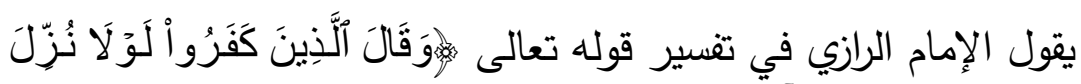

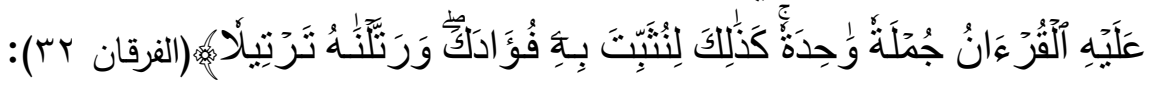
》أما قوله: كذلك ففيه وجهان: الأول: أنه من تمام كلام المشركين أي جملة

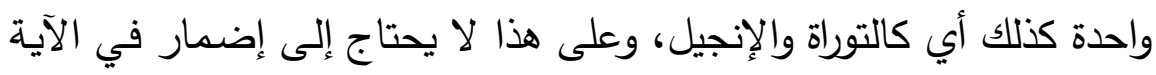

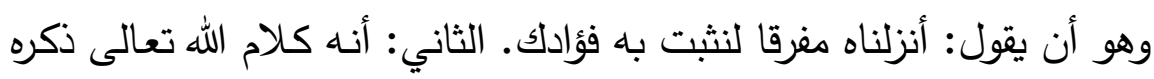

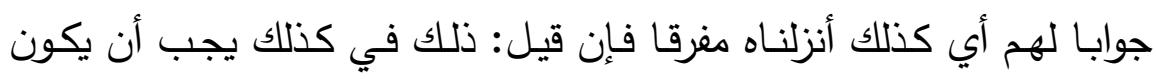

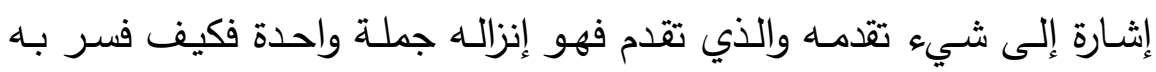

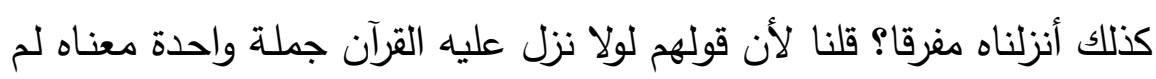

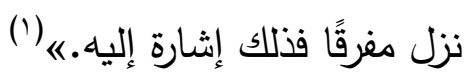
التحليل السياقي: - n

تعد (كنلك) عند أهل النحو من أسماء الإشارة وأصل وضعها (ذا) . واسم الإثارة: ما دل على معيّن بوساطة إشارة حسية أَو معنوية.

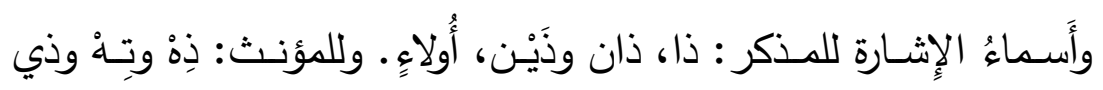

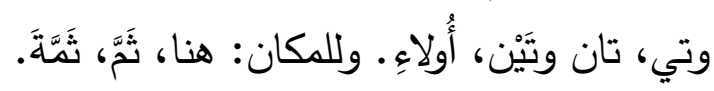

وتسبق هذه الأَسماء عدا ثـة "ها" التتبيه فنقول: هذا، هؤلاء، ها هنا. وتلحقها كاف الخطاب وهي حرف تتصرف تصرف كاف الضمير في الإفراد والتثية والجمع والتذكير والتأْيث مثل: ذالك الجبل هناك، تيكم الصحيفة لنا،

$$
\text { (') (') مفاتيح الغيب (乏 ( }
$$


ذا كُنّ مـا طلبتُنّ وذاكم مـا طلبتم. (') فالكاف في ذلك حرف خطاب تبين أحوال المخاطب يقال: ذلكَّ وذلكِ وذلكما وذلكم وذلكن. (r)

وبـالنظر لـ (كذلك) مـن رؤيسة أهل التفسير لها ومـن قائلها في الآيـة الكريمة نجد أن السياق يرشح كون (كذلك) هي من تمام كلام الخالق ـ عز وجل - ويؤكد ذلك سياقات مقاليه تأتي في شرح المفسرين للآية الكريمة منها:

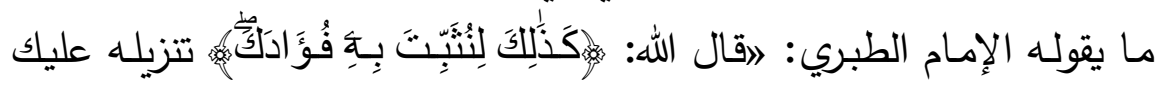
الآيـة بعد الآيـة، والثيء بعد الثيء، لنثبت بـه فؤادك نزلناه. ذكر من قال ذلك: حدثي ححم بن سعد، قال: حدثني أبي، قال: حدثي عمي، قال: حدثي التي

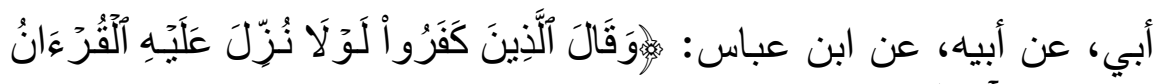

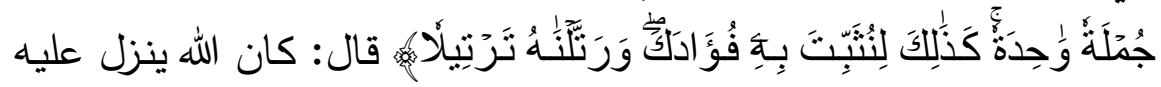
الآيـة، فإذا علمها نبيّ الله نزلت آيـة أخرى ليعلمه الكتاب عن ظهر قلب، ويشبت به فؤاده.ی(r) ويقول السمرقندي: 》يقول الله تعالى: كذلك يعني: هكذا

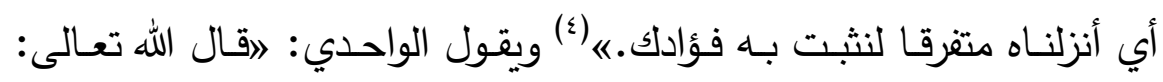

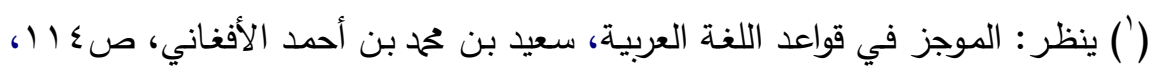

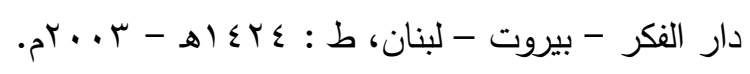

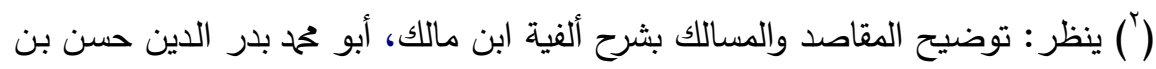

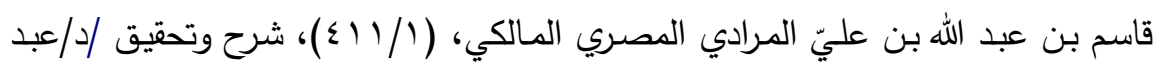

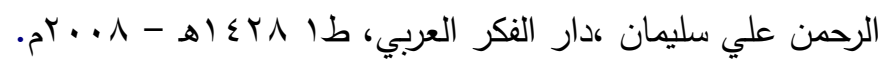

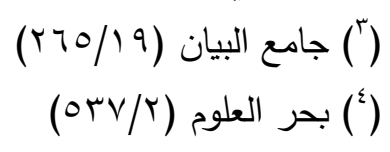




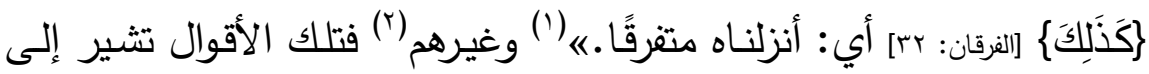
أن (كذلك) في الآية الكريمة من تمام كلام الخالق ـ سبحانه وتعالى ـ . وهناك سياق مقالي آخر يتضح من إعراب الكاف في (كذلك) ف 》الكاف

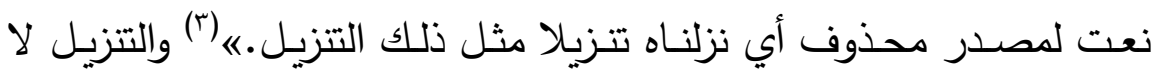
يكون إلا من الخالق ـ عز وجل ـ فدل ذلك على أن لفظة (كذلك) من تمام كلام الله تعالى.

الاستنتاج: - الاس

في هـا المبحث يبـرز لنـا دور السـياق المهـ في تعيين المـتكلم في النصـوص المحتملـة لتأويلات عدة في النـاطقين بهـا، فــن خـلال التحليـل السياقي يتم تحديد متكلم بعينه دون غيره، فالسياق تمكن من تحديد القائل في العبارات والألفاظ المختلف في قائليها للدى المفسرين كمـا حدث في (تملى، وحجرًا محجورا، وكذلك) الواردة هنا.

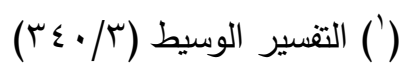

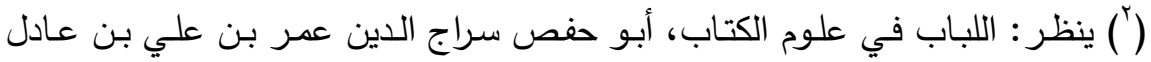

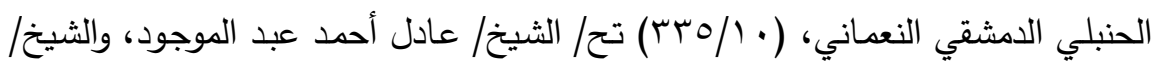

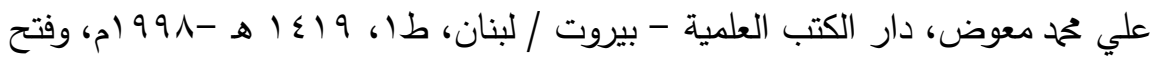

$$
\begin{aligned}
& \text { القدير للشوكاني (§o/^) }
\end{aligned}
$$

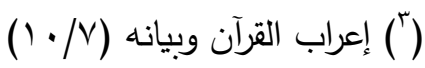




\section{المبحث الخاهس - (المس}

\section{السياق القرآني وأثره في تعيين عودة الضمير}

من الأمور اللغوية التي يجب أن نحتكم فيها للسياق عند الاختلاف في المراد منها عود الضمير، فللسياقات الخارجية والداخلية دور بالغ في مسألة

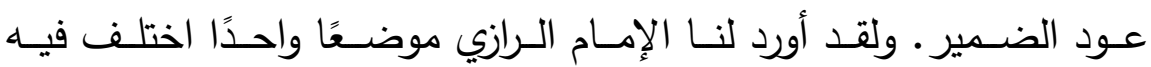
المفسرون في عود الضمير في سورة الفرقان، وهو علام يعود ضمير الهاء

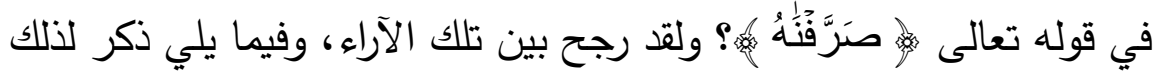
الاختلاف وبيان دور السياق في تعيين رأي بعينه وبيان مدى موافقة السياق لرأي الإمام الرازي فيما ذهب إليه من الآراء .

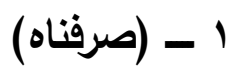

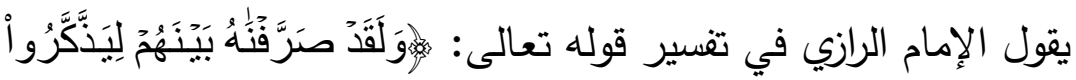

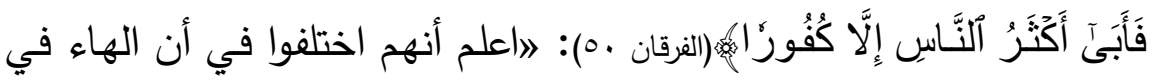
قوله: ولقد صرفناه إلى أي شيء يرجع وذكروا فيه ثلاثة أوجه: أحدها: وهو إلهو

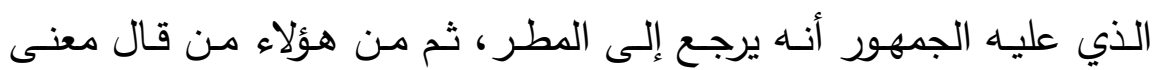
(صـرفناه) أنـا أجرينـاه في الأنهار حتى انتفعوا بالشـرب وبالزراعات وأنـواع المعاش به، وقال آخرون معناه أنه سبحانه ينزله في مكان دون مكان وفي عام دون عام، ثم في العام الثاني يقع بخـلاف مـا وقع في العام الأول... وثانيها: وهو قول أبي مسلم: أن قوله: صـرفناه راجع إلى المطر والريـاح

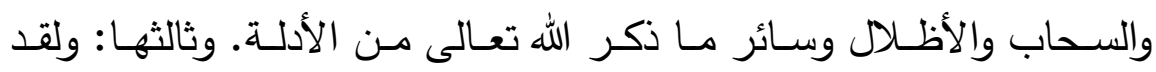
صـرفناه أي هذا القول بين الناس في القرآن وسائر الكتب والصـف التي 
أنزلت على رسل وهو ذكر إنشاء السحاب وإنزال القطر ليتفكروا ويستدلوا بـه على الصانع، والوجه الأول أقرب لأنه أقرب المذكورات إلى الضمير •«(') التحليل السياقي: - n الالالة اللغوية لـ (صرف):

مادة (ص ر ف) تدل على الرجوع والتغيير، يقول ابن فارس في دلالتها اللغويـة: \(صـرف) الصـاد والراء والفاء معظم بابه يدل على رجع الثـيء. من ذلك صرفت القوم صرفًا وانصرفوا، إذا رجعتهم فرجعوا.ی(؟) ويقول الراغب في دلالتها أيضًا: االصَّـرْفُ: ردّ الثـيء مـن حالـة إلى

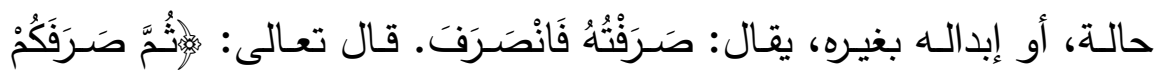

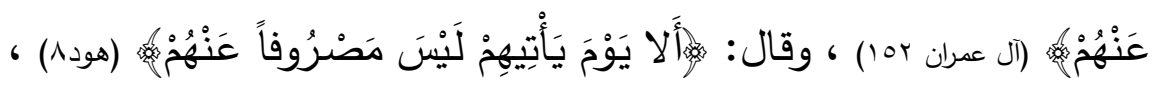

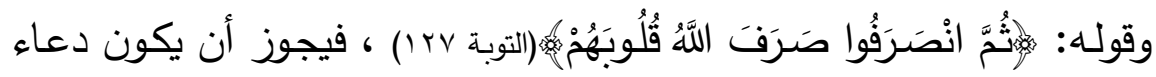

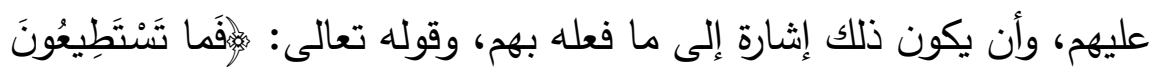

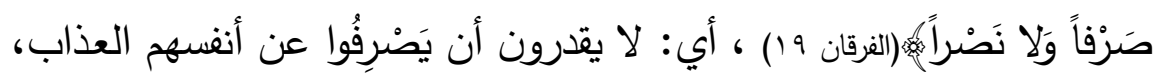

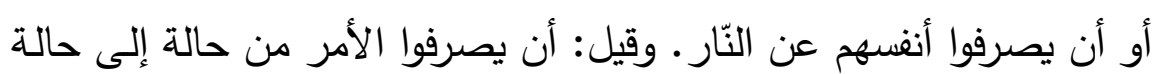

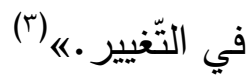

وخصها د/ جبل بالتحول المصحوب بالحدة، فيقول في معناها المحوري هو : اتحول مع حدة. كاللبن الذي يُنْصَرَف به: يتحول بـه عن الضرع حارَّا، وكالسَـعَف الذي يسبس: تحـول عن الخضـرة إلى الجفـاف، وكالثـراب الذي لـي

$$
\begin{aligned}
& \text { (') (') مفاتيح الغيب ( }
\end{aligned}
$$

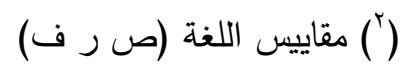

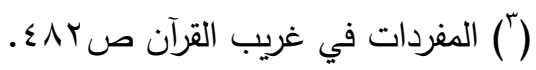




\section{مجلة قطايع كليات اللفة العريية والشعب المناظرة لها العذد [ri]}

حَلُص: تحول إلى حالة الصفاء وهو حينئذ في أقوى حالاته.ه(') تلك دلالة اللفظـة اللغويـة، وأمـا عن دلالتها عند أهل التفسير في الآيـة الكريمـة تعني رجوع مـاء المطر الذي هو أسـاس تكوينـه من الأرض قبل ارتفاعـه للسماء وتجمعه في السحب، وتلك من نعم الخالق ـ عز وجل ـ فلقد قال الإمام الطبري فيها: اليقول تعسالى ذكره: ولقد قسمنا هذا المـاء الذي أنزلنـاه من السـماء طهورًا لنحيـي بـه الميـت مـن الأرض بـين عبـادي، ليتذكروا نعسي

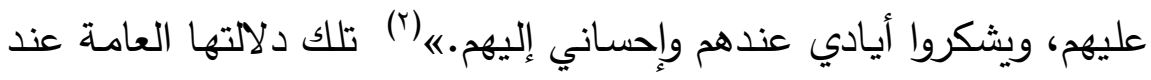
أهل التفسير ولكن اختلفوا في عود الضمير في (صرفناه) مما ترتب عليه اختلاف الدلالات التفسيرية كما سبق ذكره عند الإمام الرازي وما يعنينا هنا هو بيان دور السياق في تعيين تلك الاحتمالات:

وبالبحث عن عود الضمير في الآية الكريمـة نجد أن أكثر أهل التقسير

$$
\text { على أنه راجع إلى المطر (ץ) ويرشح ذلك سياقات لغوية منها: }
$$

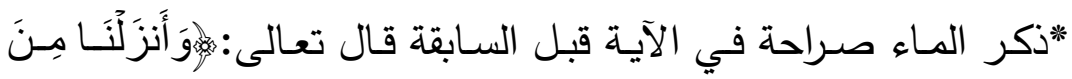

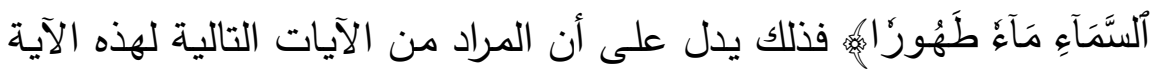
هو الحديث عن مصدر هذا الماء وهو المطر.

*أقوال المفسرين عند تفسير الآية الكريمة والتصريح بدلالة اللفظة على المطر، فيقول الطبري في تفسيرها: اولقد قسمنا هذا الماء الذي أنزلناه من

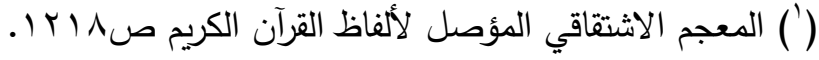

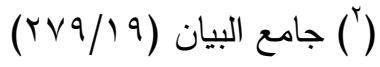

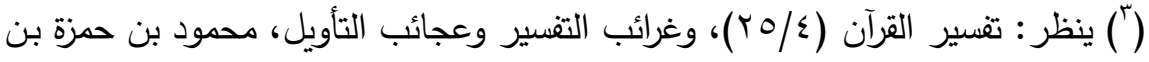

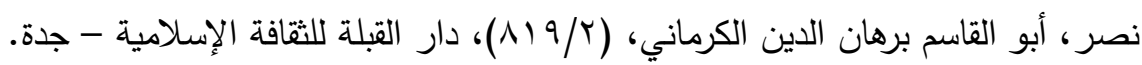


السـماء طهورا لنحيـي بـه الميت من الأرض بـين عبادي، ليتذكروا نعدي عليهم، ويشكروا أيادي عندهم وإحساني إليهم.《(') ويقول الواحدي: 》صرفنا الماء المنزل من السماء مرة لبلدة ومرة لبلدة أخرى.《(؟) ويقول السيوطي:

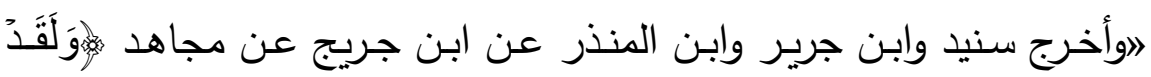

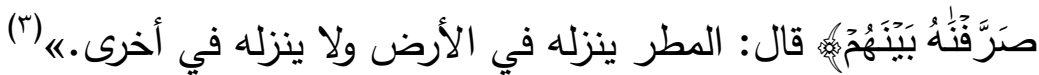
فلقد صـرح المفسـرون بلفظـة المطـر في تفسيراتهم، وذلك يؤكـد عـود

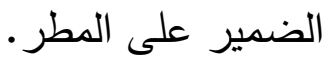

\section{الاستنتناج:}

مما سبق يتضح لنا دور السياق في تعيين المراد من الضمير وعلام يعود في النصـوص، ولا سـيما القرآنيـة منها، فالضـمير هنـا في كلمـة (صـرفناه) الواردة في الآية الكريمة يعود على المطر وأكد ذلك السياقات اللغويـة التي

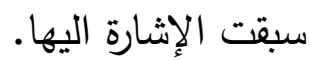

$$
\begin{aligned}
& \text { (') جامع البيان (YVq/19) }
\end{aligned}
$$

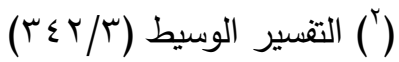

(") الدر المنثور في التفسير بالمـأثور، عبد الرحمن بن أبي بكر ، جـالال الدين

$$
\text { السيوطي، (T/ آب) ، دار الفكر - بيروت. }
$$




\section{المبهث السادس}

\section{السياق القرآني وأثره في تعيسن دلالة المشتزك اللفظي}

من أبرز القضايا اللغوية التي نلجأ فيها للسياق لتحديد المعنى المراد من الألفاظ تلك الألفاظ المشتركة المعنى، فاللفظة الواحدة قد تحتمل عدة معاني، ولا سبيل لدينا إلا السياق للوقوف على المعنى المراد منها، ولقد وردت تلك الظـاهرة للى الإمـام الرازي في تفسيره في مواضـع متعددة، سنعرض بعضًا

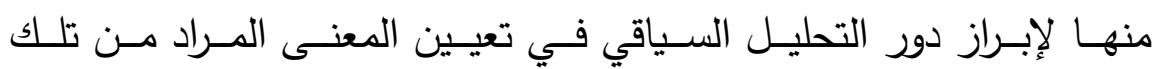
الاحتمالات من الألفاظ التي اختلف المفسرون في المراد منها وأوردها لنا الإمام الرازي في تفسير سورة الفرقان:

$$
\text { - }
$$

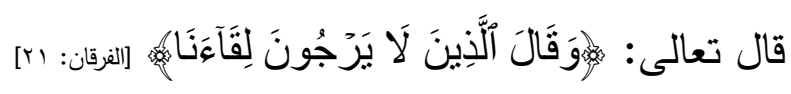

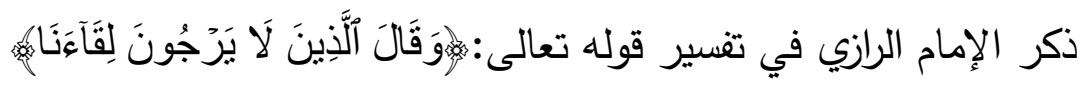
[الفرقان: اب[ أقوال المفسرين في لفظة يرجون واختلافهم في المعنى المراد منها، فقال: اوذكروا في تفسير يرجون وجوها: أحدها: وهو الذي قاله القاضي وهو

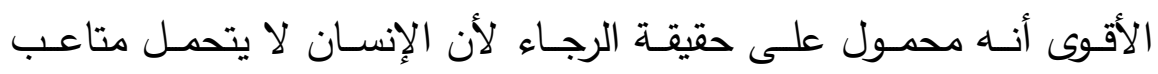

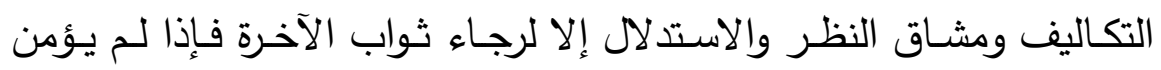
بالآخرة لم يرج ثوابها فلا يتحمل تلك المشاق والمتاعب. 
وثانيها: معناه لا يتوقعون نشورًا وعاقبة، فوضع الرجاء موضع التوقع لأنه إنما يتوقع العاقبة من يؤمن، وثالثها: معناه لا يخافون على اللغة التهامية،

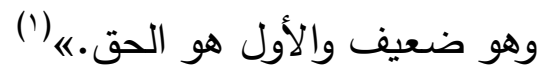
التحليل السياقي:

بالنظر في النص السـابق نجد أن الأمـام الرازي جمع أغلب أقوال المفسرين في المراد بلفظة الرجاء هنا، وأيضًا حكم عليها من حيث الرجحان

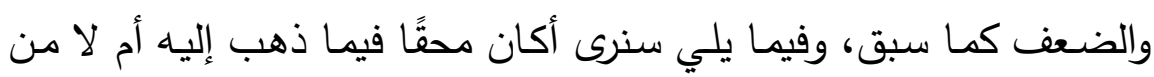
خلال السياق القائم في المقام الأول على أقوال اللغويين والمفسرين: عند اللغوبين: بالبحث عن أصل دلالة (يرجون) نجدها مأخوذة من (رجي) وفي أصل دلالتها تدور حول معنيين وهما الأمل وناحية الثيء كما يقول ابن فارس فيها حيث قال: 》الراء والجيم والحرف المعتل أصـلان متباينان، يدل أحدهما على الأمل، والآخر على ناحية الثيء. فالأول الرجاء، وهو الأمل. يقال

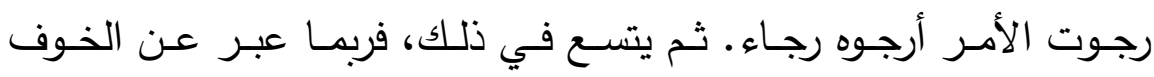

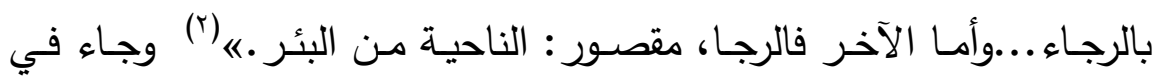
الرجاء أنه توقع محبوب يقول الراغب: 》الرّجاء والطهـع توقّع محبوب عن بن

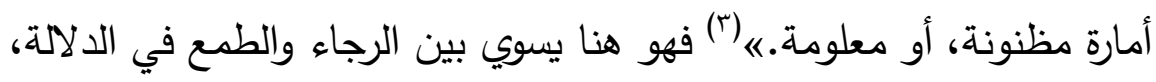

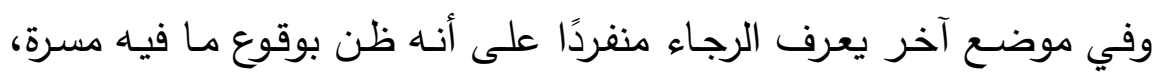

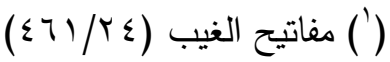

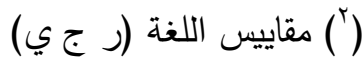

$$
\begin{aligned}
& \text { (") المفردات في غريب القرآن صس •r م. }
\end{aligned}
$$


فيقول: 》الرَّجَاءُ ظنّ يقتضي حصول ما فيه مسرّةه(') تلك دلالتها عند أهل اللغة فهي بمعنى الأمل من حيث هي توقع النفس بتحقق ما يسرها، والناحية من البئر - n

\section{عند المفسرين:}

بالتتقيب عن دلالتها في أقوال المفسرين تجد أغلبهم يؤيد دلالة الرجاء على الخوف، وعدم الخشية وإن كانت لها دلالات أخرى ولكن دلالتها هذه هي الدلالة الغالبة عندهم ومن هؤلاء: الطبري حيث يقول: الوقال المشركون الذين لا يخافون لقاءنا، ولا يَخْشَون

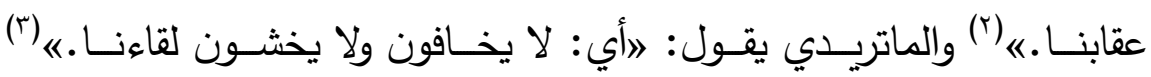

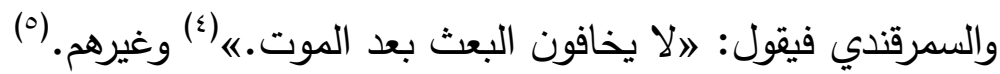

$$
\begin{aligned}
& \text { (') السابق ص זٓ؟ז. }
\end{aligned}
$$

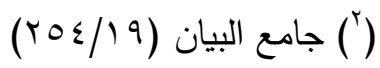

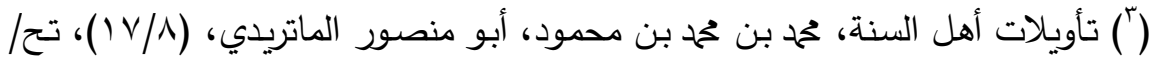

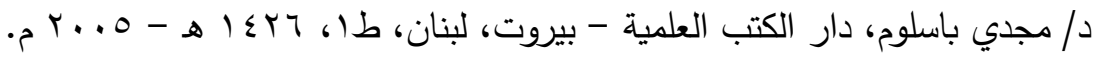

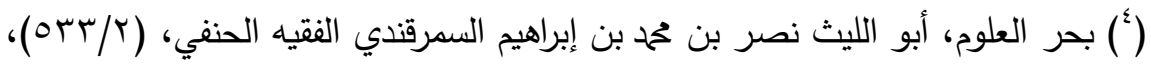

$$
\text { تح/ د/ محمود مطرجي، دار الفكر - بيروت. }
$$

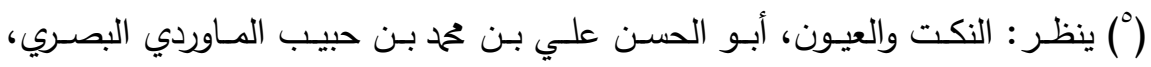

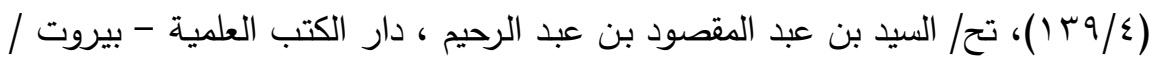

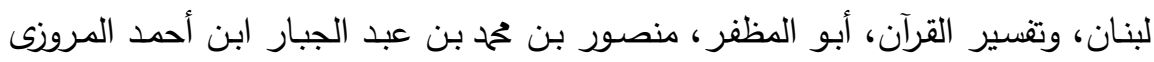

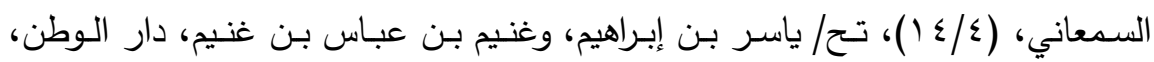

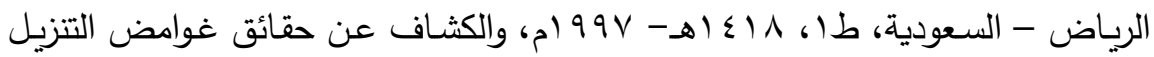

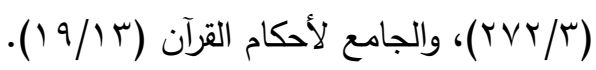


وهنالك تأويلات بدلالات أخرى ولكن كما سبق الغالب بينهم إجماعهم على دلالمة الخوف ولم أجد ـ فيما قرأت ـ من يقول بضعف دلالة الرجاء على الخـوف كمـا قال الإمـام الرازي ـ في النص موضـع الدراسـة والتحليل السابق الإشارة إليه في الصفحة السابقة من هذه الدراسـة ـ حتى وإن كانت

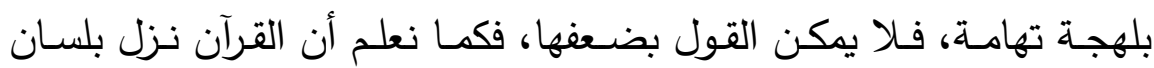
العرب ولهجاتهم، وإن كانت الآيـة تحتمل دلالة الرجاء على حقيقته ولكن الأقرب هنـا هي دلالـة السياق، فمـن لـم يؤمن بـاله فلن يخثـاه تعـالى ولن يخاف من لقاء الخالق عز وجل. وأيضًا جاءت دلالة الرجاء في هذه الآية الكريمة على الخوف في كتب

(') الوجوه والنظائر وبذلك تكون دلالـة الرجاء على الخوف وعدم الخشية رشحت بسياقات لغوية من أقوال المفسرين. وهناك سياق لغوي ثانٍ يرشح دلالة الرجاء على الخوف وهو ما جاء في الأحاديث النبوية الشريفة، في بيان أهمية الخوف من الخالق ـ عز وجل ئل

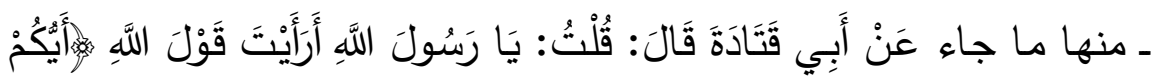

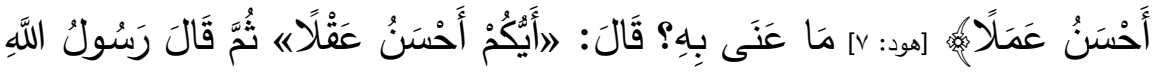

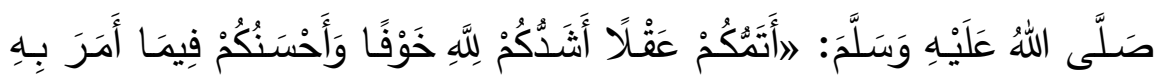

(') ينظر : نزهة الأعين النواظر في علم الوجوه والنظائر، جمال الدين أبو الفرج عبد

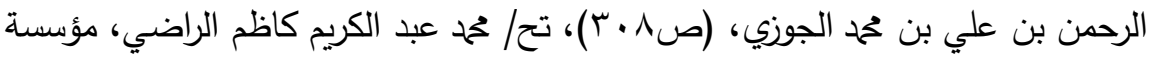

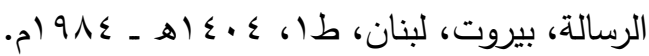




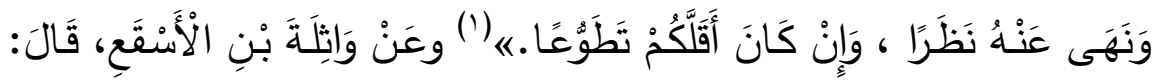

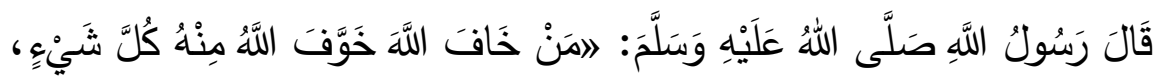

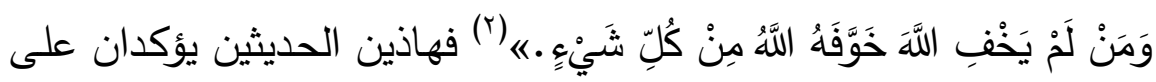

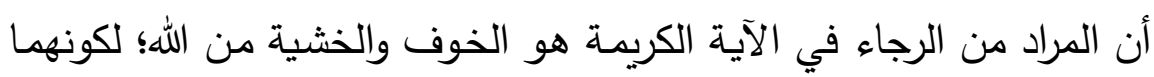

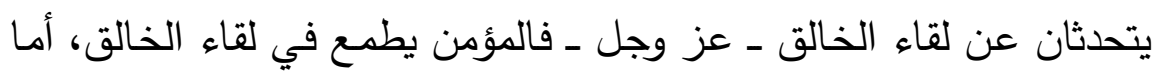
الكافر فيخاف من هذا اللقاء لمعصيته لخالقه ـ جل وعلا ـ، وهذا هو حال الكفار الذين تتحدث عنهم الآية الكريمة التي بين أيدينا.

وسياق لغوي ثالث جاء في أقوال الصالحين، التي تؤكد لنا أن الرجاء الذي هو بمعنى الخوف من الخالق ـ عز وجل ـ ومن لقائه حتى بالنسبة

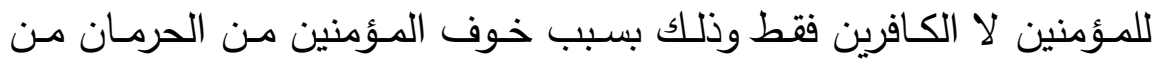
الثواب وخوف الكافرين من وقوع العقاب عليهم هو المقصود هنا ومن هذه

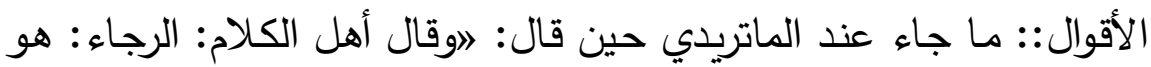

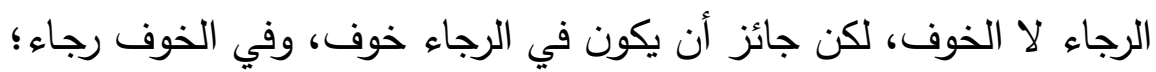

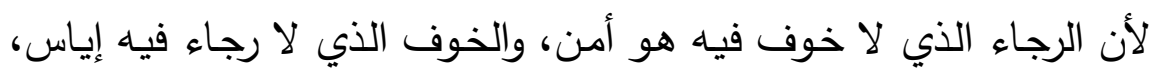

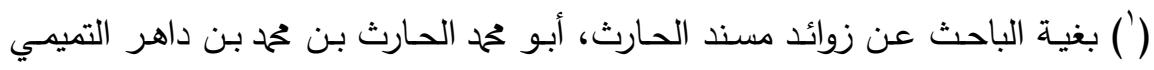

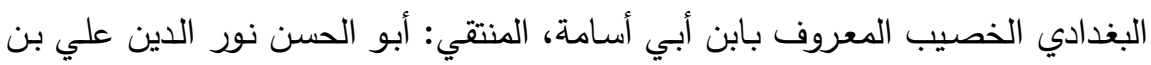

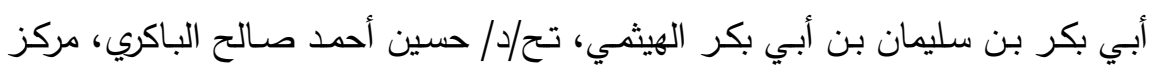

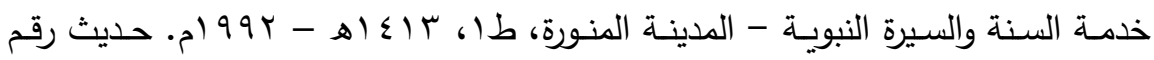

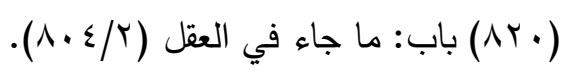

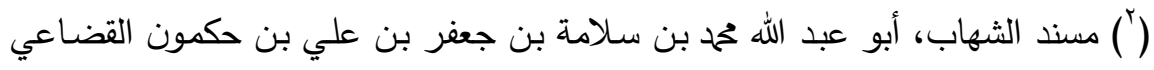

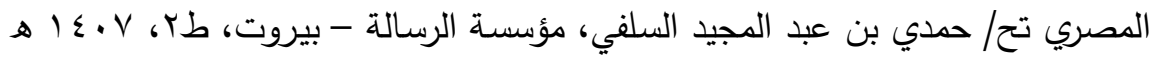

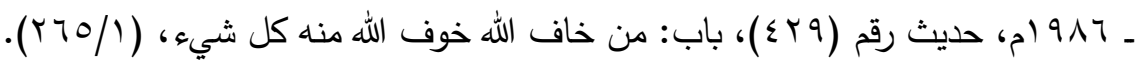


فكلاهما مذمومان: الإياس والأمن جميعًا.ی)(') وجاء عند ابن عبد ربـه: " وقـال الحسـن: مـن خـاف الله أخـاف الله منـه كل شـيء، ومـن لـم يخفـ الله أخافه الله من كل شيء.ب(ז) وقال مسروق: "إنّ المخافة قبل الرجاء فإنّ الله تعالى خلق جنّة ونارًا فلن تخلصوا إلى الجنّة حتى تمرّوا بالنار .ی)(؟) وقيل: اأن الخوف مقام جليل من مقامـات العارفين، وهو أحد الأركان التي هي أصسول هذا الفن، وهو التقوى التي حث الله تعالى عليها، وقال: إن أكرم الناس عنده أشدهم خوفا له، وفى هذه الآية وحدها كفاية، وإذا نظرت القرآن العزيز وجدت أكثره ذكر المتقين، وهم الخائفون.《() فنرى أن الأقوال السابقة وهده أكدت عدم الاطمئنان الذي ينتاب المخلوق عند لقاء الخالق ـ جل شأنه ـ فبذلك كان الرجاء مشوبًا بالخوف، وتلك الدلالة أشـار إليها د/ جبل عندما ربط بين دلالتي مادة (ر ج و) على الخوف والناحية من البئر في معجمهـ حيث قال: اوإشراف الجدار ونحوه على الماء يؤخذ منه الإشراف على نيل خير، كمـا يثـعر بـنقص الاطمئنـان إلى يقينيـة الحصـول عليـه، وهذا هـو

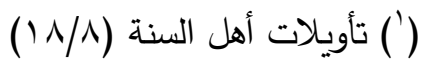

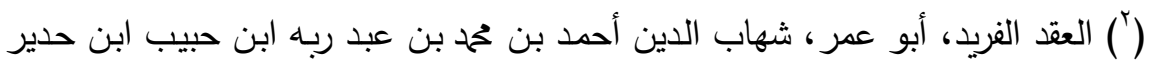

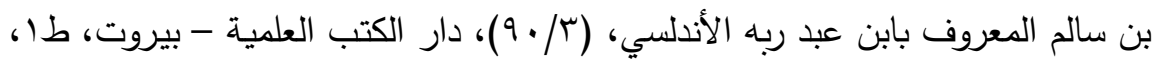

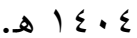

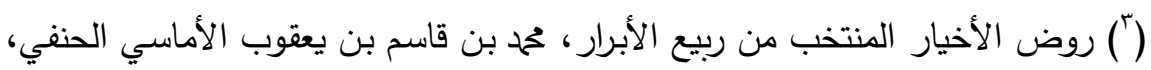

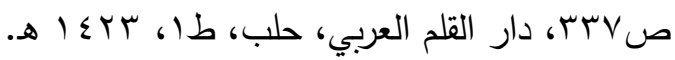

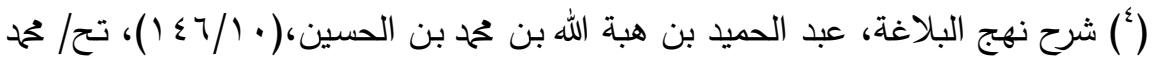

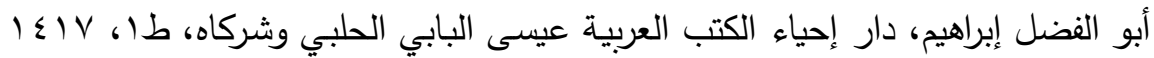


الرجاء بمعنى الأمل والطمح؟ لأن الراجي ليس مطمئنًا متيقنًا بحصول ما

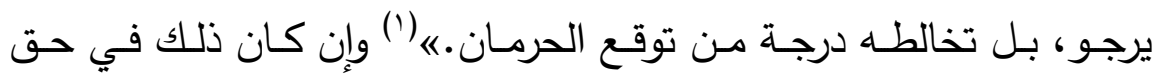
المؤمنين، فكيف هو الحال لهؤلاء الكفار الذين لا يؤمنون باله تعالى فلا خشية لديهم ولا خوف من الحساب. مما سبق يتبين لنا أن المراد بالرجاء في الآية الكريمة هو عدم الخشية والخوف من الحساب، فهي التي تتاسب السياق القرآني هنا.

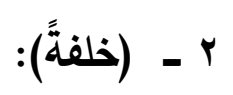

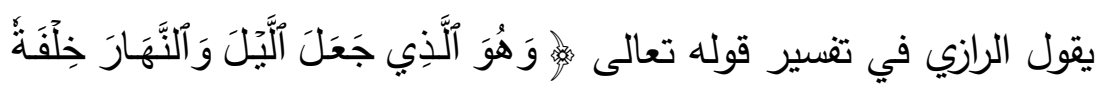

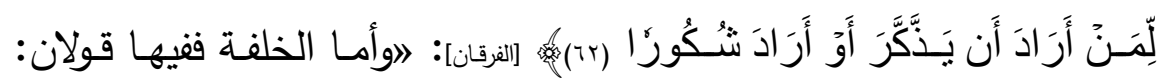

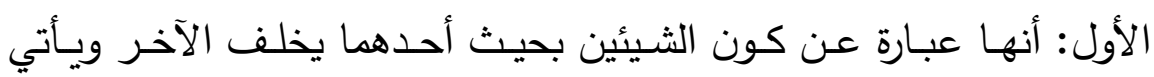
خلفه... والمعنى جعلهما ذوي خلفة أي ذوي عقبة يعقب هذا ذالك وذاك هذأ هذا.

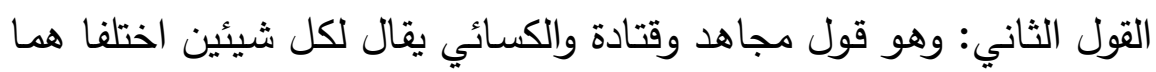

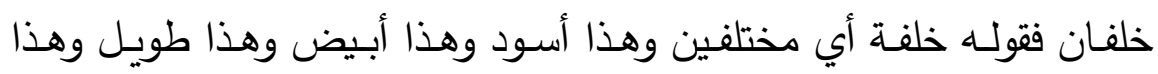

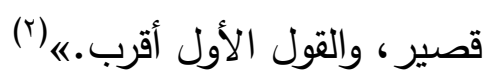
التحليل السياقي: - n لفظة (خِلفة) مأخوذة من (خلف) يقول ابن فارس في أصلها: االخاء

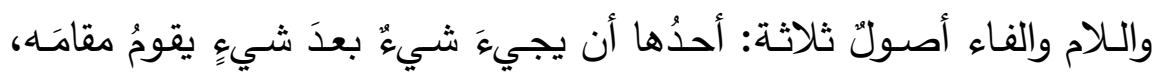

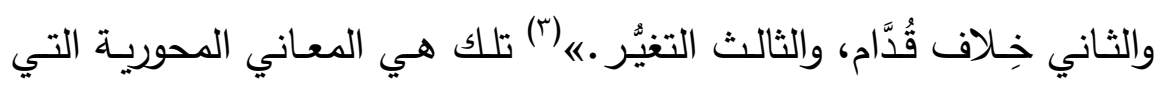
(') المجم الاشتقاقي المؤصل لألفاظ القرآن الكريم ص VON. (')

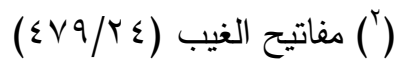

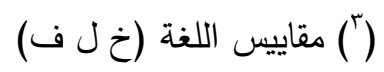


تدور حولها المادة، وما يستوقفنا هنا هو ما قاله اللغويون عن دلالة اللفظة في هذه الآية الكريمة، يقول ابن دريد: اويقال لكل شيء كان بدلاً من شيء

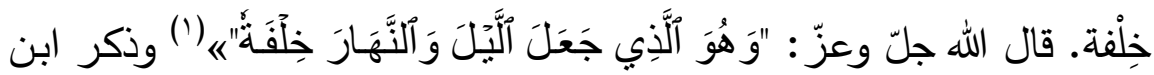
منظور أن: 》الخلفـة اختلاف الليل والنهار وفي التتزيـل العزيز وهو الذي ولي جعل الليل والنهار خلفة، أي: هذا خلف من هذا يذهب هذا ويجيء هذا.ی(؟) فالخلفة تعني هنا مجيء الثاني عوضًا عن الأول أو مكانه فكلاهمـا يأخذ مكان الآخر وتعد تلك سياقات لغويـة تؤكد دلالة الخلفة على التعاقب بين الليل والنهار لا اختلافهما. وهناك سياقات لغوية أخرى تؤكد تلك الدلالة جاءت عند المفسرين: يقـول الطبري: اوإنمـا "الاختلاف" في هذا الموضـع "الافتعـال" مـن

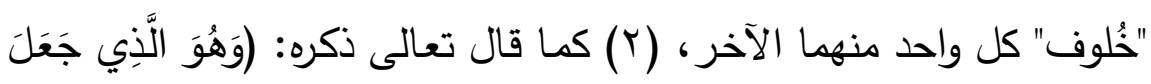

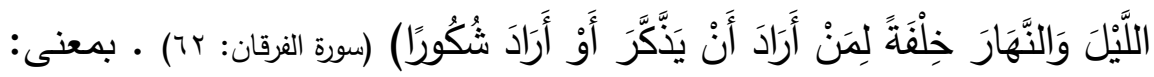

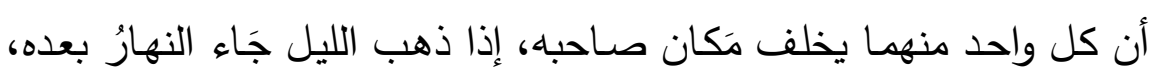
وإذا ذهب النهارُ جاء الليل خلفه. ومن ذلك قيل: "خلف فلانٌ فلانًا في أهله (r): بسوء"، ومنه قول زهير

$$
\text { (') (') جمهرة اللغة (خ ل ف) لسان العرب (خ ل ف) }
$$

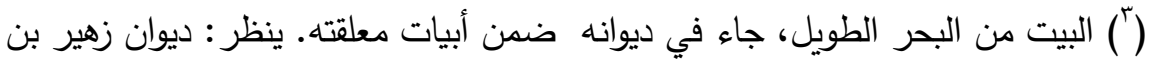

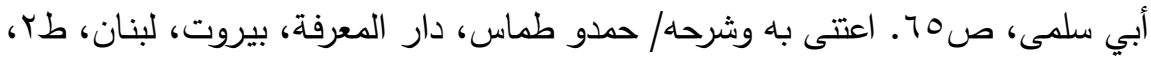

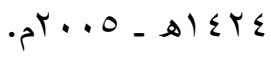




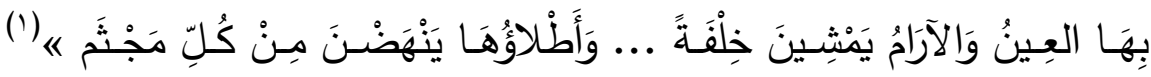
والمعنى ذاته جاء عند الزمخشري حيث يقول: „الخلفة من خلف، كالركبة من ركب: وهي الحالة التي يخلف عليها الليل والنهار كلّ واحد منههـا

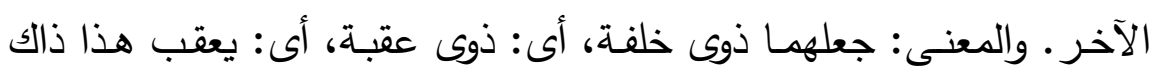

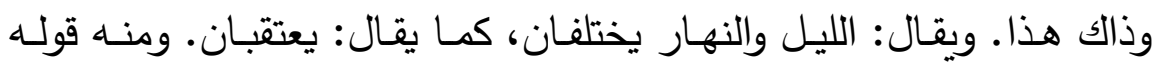

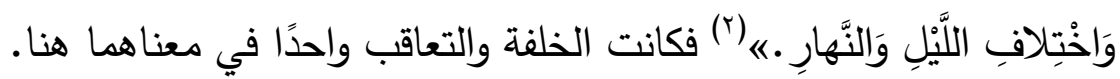
ويقول الثـيخ الثعراوي: "حين يتكلم الحق عن الإنسان فهو سبحانه

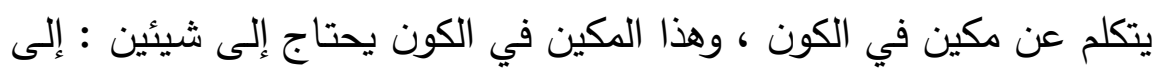

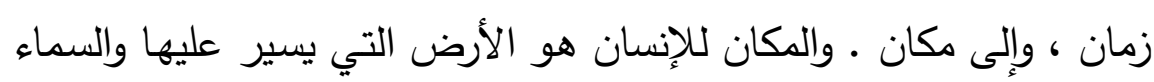

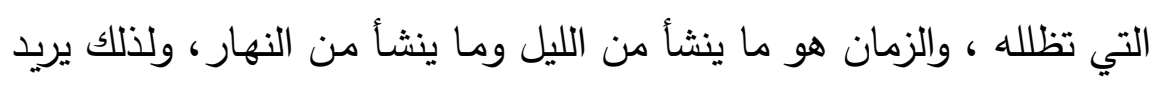

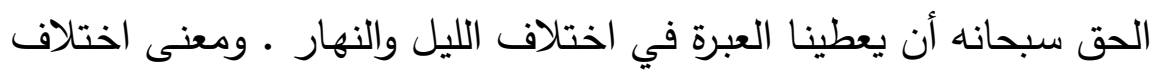

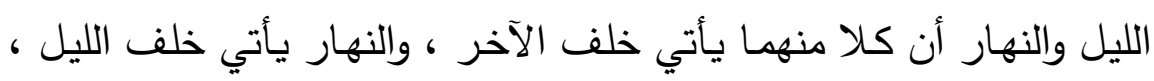

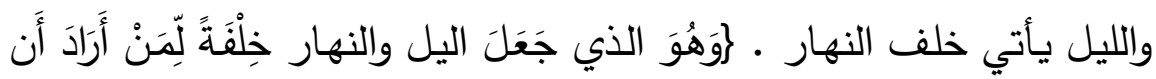

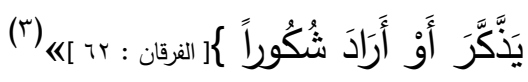

مما سبق نرى أن تعاقب الليل والنهار جاءت عند المفسرين تدل على

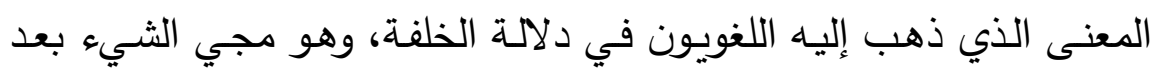

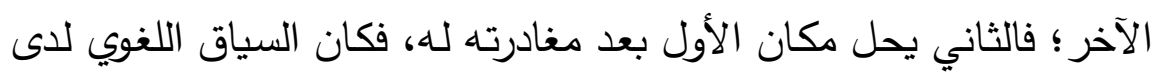
المفسرين يرشح من الدلالتين المذكورتين لاى الإمام الفخر الرازي : دلالئة

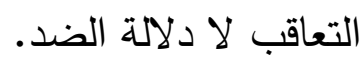

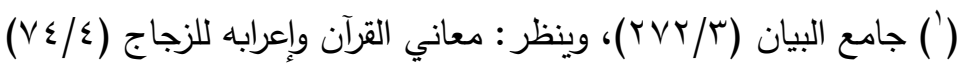

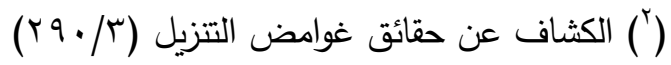

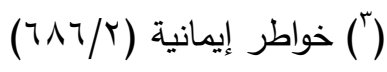


وهنالك نوع ثالث من السياقات اللغويـة التي تؤكد دلالتها على التعاقب

$$
\text { وهو الأحاديث النبوية التي جاءت في المعنى ذاته ومنها: }
$$

ما جاء في تفسير سورة الفرقان في تلك الآية الكريمة لاعَن ابْن عَبَّاس وَقَتَادَة: خلفـة، يَعْنِي عوضـا وخلفاً يقوم واحدهما مَكَان صَـاحبه، فَمـن فَاتَهُ عمله فِي أَحدهمَا قَضَاهُ فِي الآخر ل... وَعَن ابْن زيدا: يَعْنِي إِذا جَاءَ أَحدهمَا

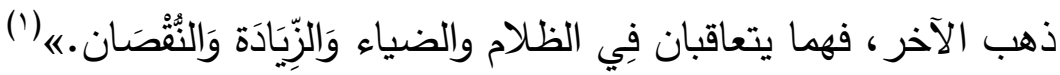
فتلك السياقات اللغوية تؤكد على دلالة لفظة (خلفة) على التعاقب، وهذا هو الأنسـب للسـياق؛ فالليل والنهار يكمـلان بعضـهما، فـلا يعدان ضـدين فاكتمال اليوم بهما. فهما كالثريكين في شيء واحد.

$$
\text { r- (يسرفوا - يقتروا): - (يقا) }
$$

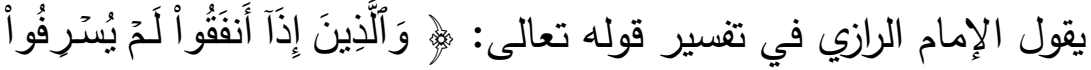

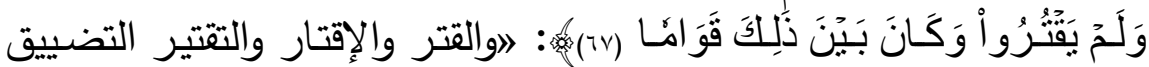
الـذي هـو نقـيض الإسـراف، والإسـراف مجـاوزة الحـد فـي النفقـة. وذكـر المفسـرون في الإسـراف والتقتيـر وجوهـا: أحـدها: وهـو الأقوى أنسه تعـالى وصفهم بالقصد الذي هو بين الغلو والتقصير وبمثله أمر رسوله ـ صلى الله

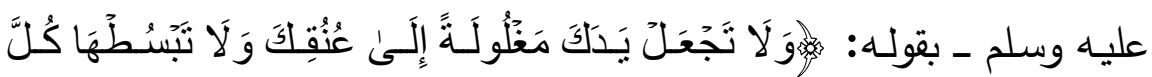

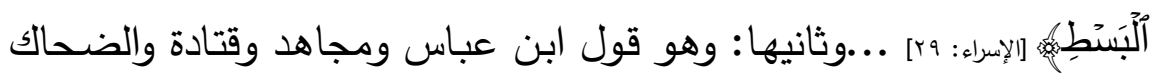
أن الإسراف الإنفاق في معصية الله تعالى، والإقتار منع حق الله تعالى...

(') عمدة القارئ شرح صحيح البخاري، أبو محمد محمود بن أحمد بن موسى بن أحمد بن

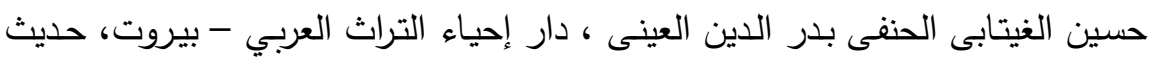

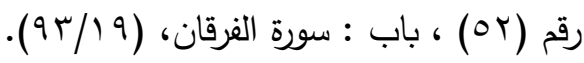


وثالثها: المراد بالسرف مجاوزة الحد في التنعم والتوسع في الدنيا، وإن كان من حلال، فإن ذلك مكروه لأنه يؤدي إلى الخيلاء، والإقتار هو التضييق

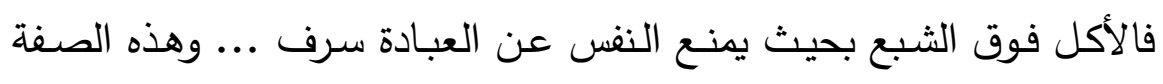
صفة أصحاب محمد ـ صلى الله عليه وسلم ـ كانوا لا يأكلون طعامًا للتنعم

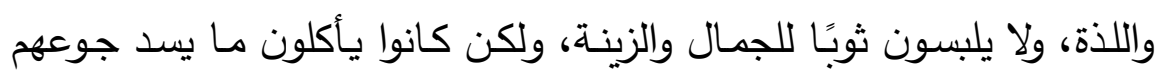

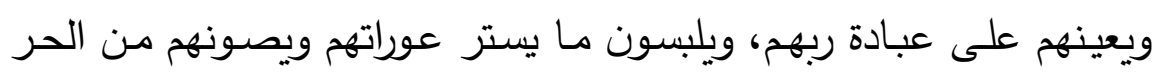

والبرد.《) (1)

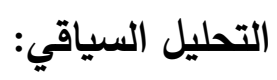

لفظة (يسرفوا) مأخوذة من (سرف) يقول ابن فارس في أصل دلالتها:

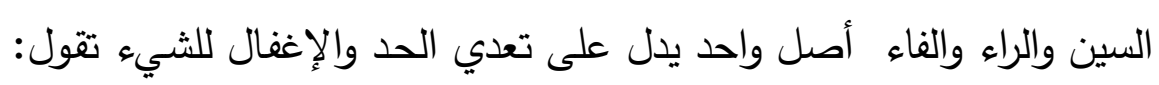

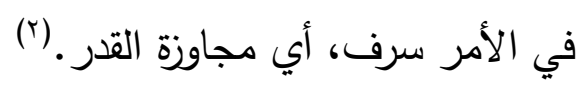

ولفظة (يقتروا) مأخوذة من (قتر ) ،يقول ابن فارس في أصل دلالتها:

》القاف والتاء والراء أصل صحيح يدل على تجميع وتضييق. من ذلاك القترة: بيت الصائد؛ وسمي قترة لضيقه وتجمع الصائد فيه؛ والجمع قتر ـ والإقتار :

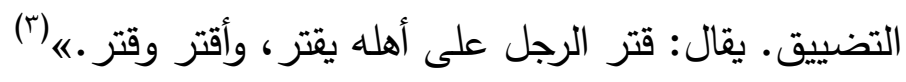

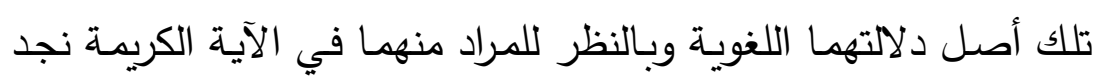
أن هذه الآية الكريمة جاءت ضمن آيات 》الثوط الأخير في السورة فيبرز

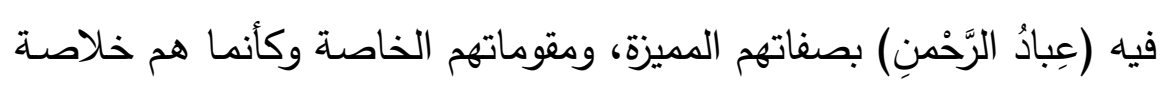

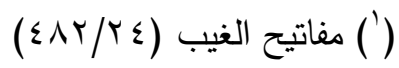

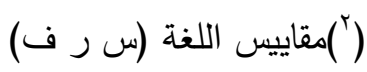

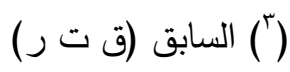


البشرية في نهاية المعركة الطويلة بين الهدى والضـلال. بين البشرية الجاحدة المشاقة والرسل الذين يحملون الهدى لهذه البشرية. وكأنما هم الثمرة الجنية لذلك الجهاد الثـاق الطويـل، والعـزاء المـريح لحملـة الهـى فيمـا لاقوه مـن جحود وصلادة وإعراض!.《(') فتلك الآيات تتحدث عن صفات عباد الرحمن في الحيـاة الـنيا ومسن جملـة تلك الصـفات مـوقفهم مسن الإنفـاق والتزامهم بالتوسط والاعتدال فيه، فكان المعنى الأنسب للسياق هنا هو المعنى الثالث لكونه مرشحًا بسياق المقام، وهو الحديث عن صفات عباد الرحمن. وهناك سياق مقالي آخر يرشح تلك الدلالة ورد في تتمـة الآية الكريمة

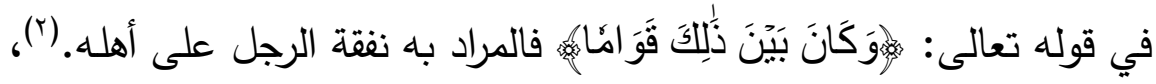
والواو هنا عاطفة أو حالية.() وبالنظر لكونها عاطفة، فهي مرتبطة بما قبلها مما يؤكد دلالمة الآية على أن من صفات عباد الرحمن التوسط والاعتدال بين الإسراف والتقتير في الإنفاق في الدنيا والتمتع بالنعم فيها. وأيضًا يرشح تلك الدلالة هنا وهي التوسط والاعتدال والقيام بالأمور على كلى وجهها الصـيح دلالتة الإسـراف التي جاء ذكرها في كتب الوجوه والنظائر

(') (') في ظلال القرآن (roVv/0)

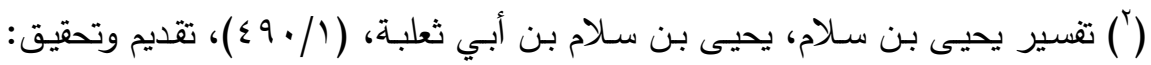

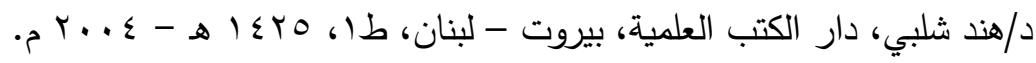

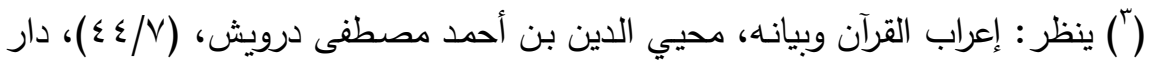

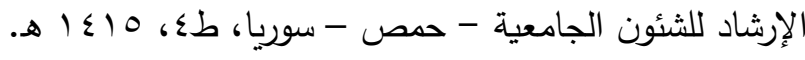




\section{مجلةققطاع كليات اللفة العريية والشعب المناظرة لها العذد [rا]}

لألفاظ القرآن الكريم، وهي دلالتها على خـلاف مـا يجب(') فجاءت الآيـة الكريمة لتنفي ذلك عن عباد الرحمن.

وبذلك يكون سياق السورة الكريمـة يرشَح الدلالـة الثالثة لـ ( الإسـراف و

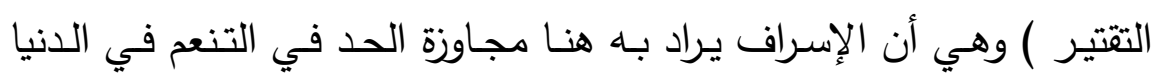
والإقتار يراد به التضييق، وتلك الصفة منفية عن المؤمنين كما سبق.

الاستنتتاج:

مما سبق يتبين لنا الدور البالغ الأهمية الذي يلعبه السياق في تعيين المعاني المحتملة من الدلالات التي تدخل تحت باب ألفاظ المشترك اللفظي، كما حدث في ألفاظ (يرجون و خلفـة و يسرفوا ويقتروا) الواردة في السورة

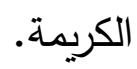

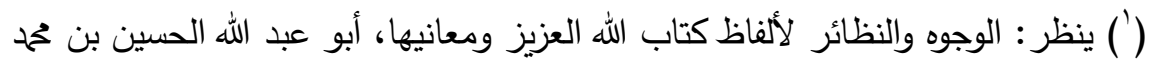

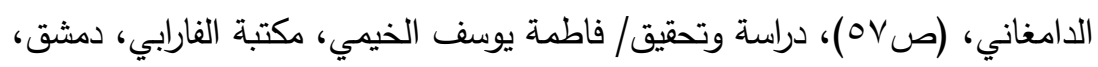

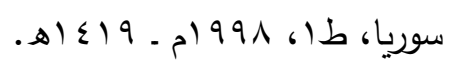


النيياق القراًأنيه وأثره فهي تعيين المعنص عند الفخر الرازيه

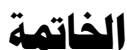

الحمد لله الذي بنعمته تتم الصالحات، والصلاة والسلام على أشرف المخلوقات، وهادي البشرية لسواء الصراط، وعلى آله وصحبه ومن تبع سنته

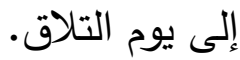

\section{وب8هد،}

فتلك دراسـة موجزة تناولت نظريـة السياق من الناحية التطبيقية، حاولت فيها بيان ما للنظريـة من قيمـة عظمى في الترجيح بين الدلالات المختلف فيها في الموضع الواحد، وهو ما يسمي بتعيين المحتمل كما سماها ابن القيم في ذكره لفائدة السياق، كما سبق. وقد أسفرت تلك الدراسة عن بعض النتائج منها: * إبراز قدرة الرازي العقلية في تعيين بعض المحتملات في تفسيره، والتي أثثتت عنايته بالسياق القرآني فيها. * مـن خـلال الدراســة بـرزت قدرة السـياق على تعيـين المحـتملات، وتأكيدها بصـورة قويـة في النص القرآني ومـن هذه الأمثلـة التي أبرزتها

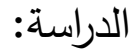

* بيان مدى أهمية السياق في تعيين الأصل الاشتقاقي للألفاظ، فبما أن اللغة العربية ثرية بالمشتقات والتي قد يضطرب البعض في تعيينها، فلزم أن نلجأ لوسيلة تحمينا من ذلك الاضطراب فكان السياق هو الأقدر على تعيين

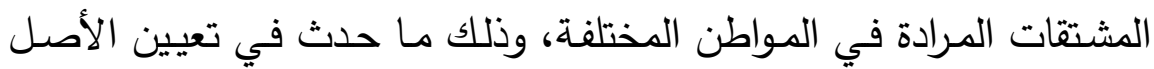
الاشتقاقي للفظتي (تبارك ، كفورا) الواردتين في السورة الكريمة. 
" التأكيد على الدور البالغ الأهمية الذي يلعبه السياق في تعيين المعاني

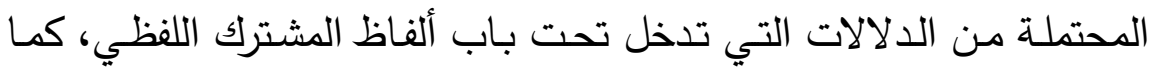
حدث في ألفاظ (يرجون و خلفة و يسرفوا ويقتروا) الواردة في السورة الكريمة. * التتبيه على دور السياق في تعيين المراد بالدلالة الزمانية في النص

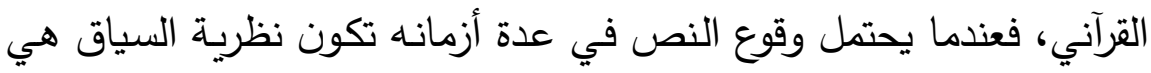

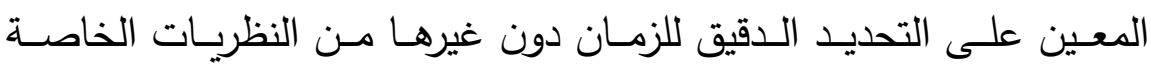
بالدلالة، كما حدث في مدلول زماني العذاب وقول النبي ـ صلى الله عليه وسلم ـ السابق الحديث عنهما في السورة الكريمة. * تمكنت الدراسة من توضيح دور السياق في تعيين المراد من الضمير

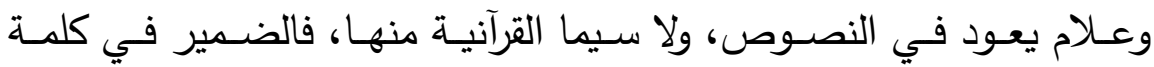
(صرفناه) الواردة في الآية الكريمة هنا يعود على المطر وأكد ذلك السياقات اللغوية التي سبقت الإشارة اليها. * ظهر من خـلال الدراسة قيمة السياق في تعيين المحتمل من معاني

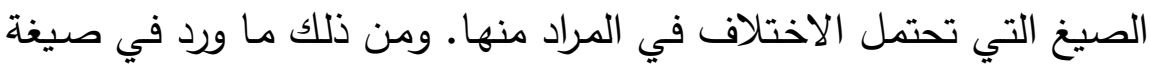
(ظهيرا) التي وردت فيها ثلاثة معاني فالسياق رشح معنيين دون الثالث وهما فيا فيأ

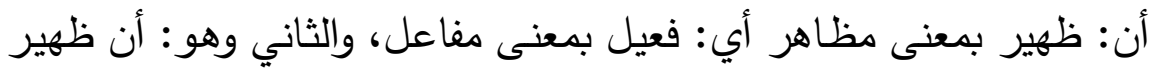

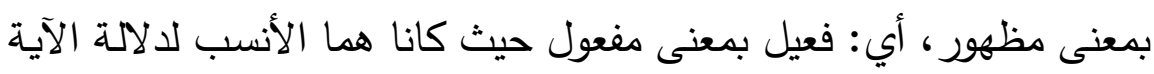
الكريمة هنا، وأكد ذلك السياق ووضحه. وآخـر دعوانـا أن العمـــ لله رب العـالمين والصـلاة والسـلام على رعى

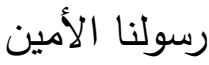


ا ـ مفاتيح الغيب، أبو عبد الله حمح بن عمر بن الحسن بن الحسين التيمي الرازي الملقب بفخر الدين الرازي ، دار إحياء التراث العربي - بيروت، طس، ه. $1 \leq r$.

\section{المراجع}

r. أنوار التنزيل وأسرار التأويل، ناصر الدين أبو سعيد عبد الله بن عمر بـن حمح الثـيرازي البيضـاوي، تـح/ تحمد عبد الرحمن المرعشـلي، دار إحيـاء

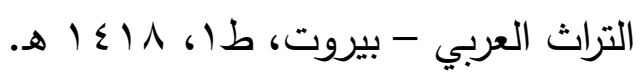

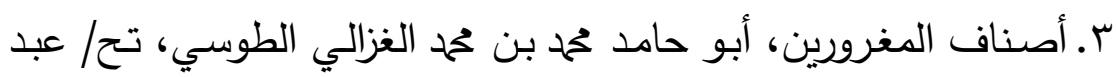

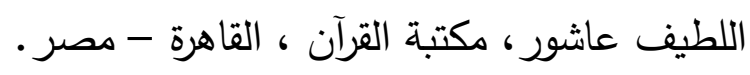
ع. أضواء البيان في إيضاح القرآن بالقرآن، ححمد الأمين بن عحمد المختار بن

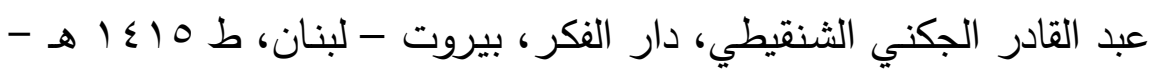
1990

ه. إعراب القرآن وبيانـه، محيـي الدين بـن أحمد مصـفى درويش، دار الإرشاد للشئون الجامعية - حمص - سوريا، طء، 0 1ـ أ هـ.

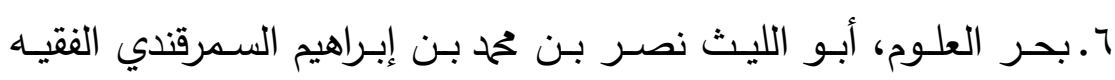
الحنفي، تح/ د/ محمود مطرجي، دار الفكر - بيروت.

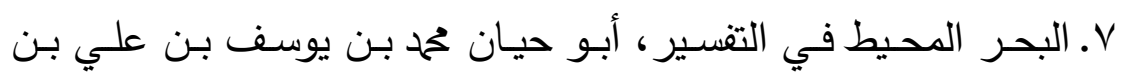
يوسف بن حيان أثير الدين الأندلسي، تح/ صدقي حمد جميل، دار الفكر بيروت، ط • ب ع ا هـ. 
ه. البحر المديد في تفسير القرآن المجيد، أبو العباس أحمد بن محمد بن

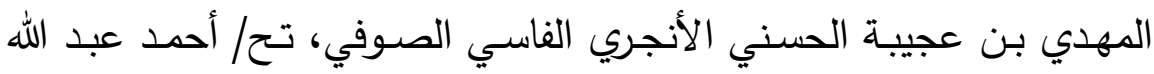

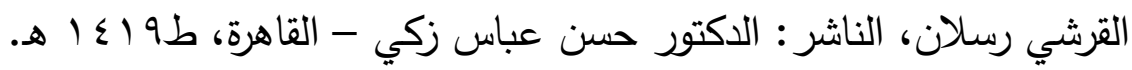

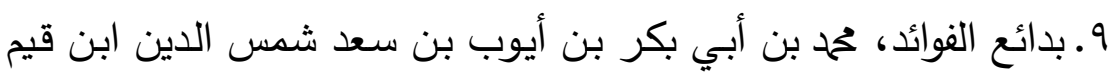
الجوزية، دار الكتاب العربي، بيروت، لبنان. • 1.بغية الباحث عن زوائد مسند الحارث، أبو محح الحارث بن محمد بن داهر لينان

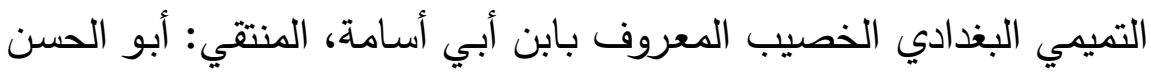

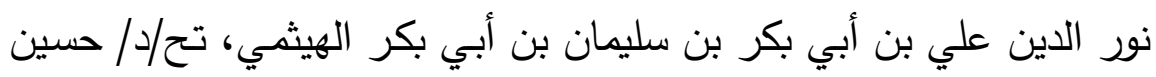

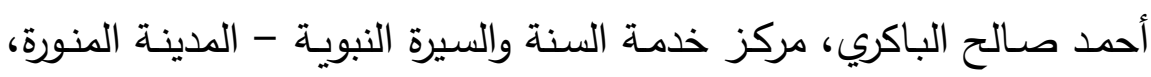

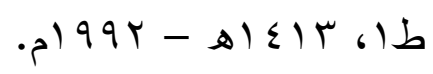

1 ا.تاج العروس من جواهر القاموس، محمّد بن محمّد بن عبد الرزّاق

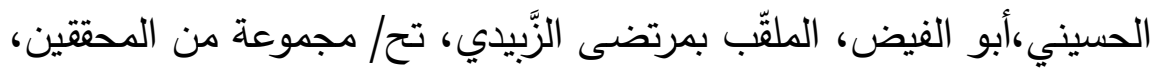
الناشر/ دار الهداية.

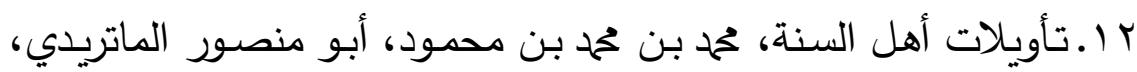

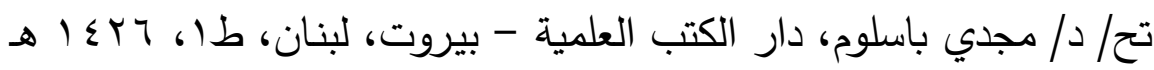
.0 r... rا ـتفسير ابن باديس (في مجالس التذكير من كلام الحكيم الخبير)،عبد

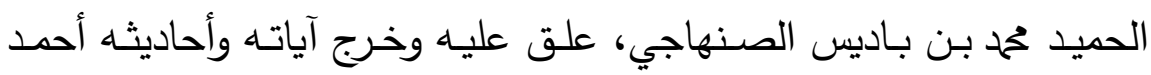

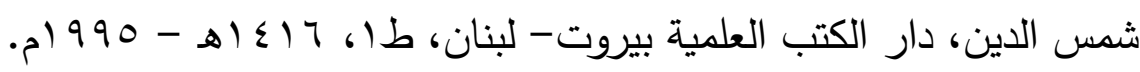

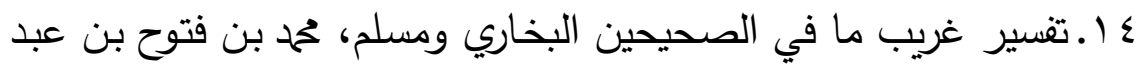

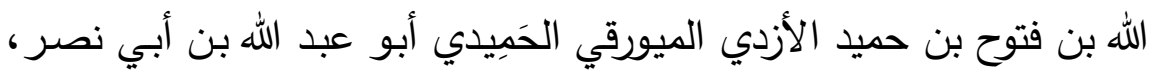

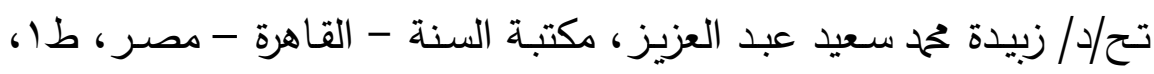
$.01990-81 \leqslant 10$ 


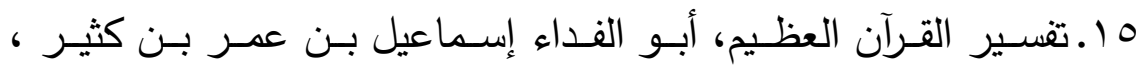

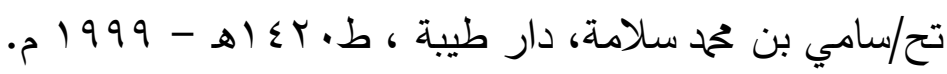
7 ا ـ تغسير القرآن، أبو المظفر ، منصور بن محهد بن عبد الجبار ابن أحمد المروزى السمعاني، تح/ ياسر بن إبراهيم، وغنيم بن عباس بن غنيم، دار

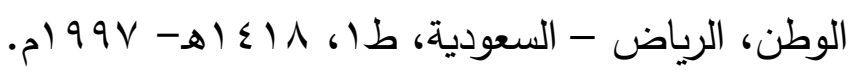

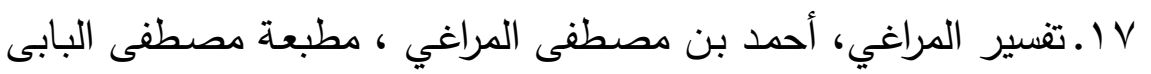
الحلبي، مصر، طا1، 1 ا ـتفير المنار (تفسير القرآن الحكيم )، محهد رشيد بن علي رضـا بن ححم شـس الدين بـن محمد بهاء الدين بـن منـلا علي خليفة القلموني الحسيني، الهيئة المصرية العامة للكتاب، طـ • 199 19 م. 9 1 التفسير الوسيط للقرآن الكريم، ححمد سيد طنطاوي، دار نهضـة مصر ،

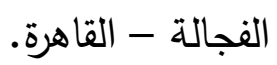
• . . تفسير غريب ما فى الصحيحين البخارى ومسلم، ححمد بن أبي نصر فتوح بن عبد الله بن فتوح بن حميد بن بن يصل الأزدي الحميدي، تح/د/

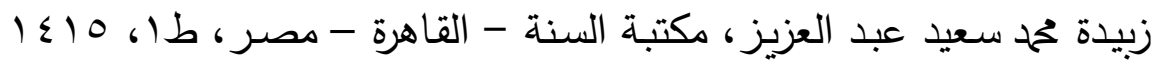

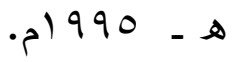

ا Y. تفسير يحيى بن سلام، يحيى بن سـلام بن أبي ثعلبة، تقديم وتحقيق:

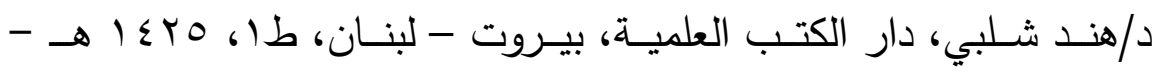

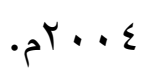

r. تـهذيب اللغـة، تحمد بـن أحمـد بـن الأزهـري الهـروي، تـح/ عحمد عـوض

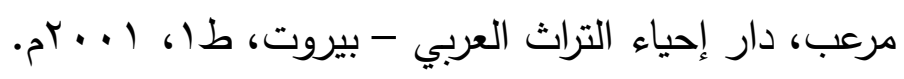


r r. توضيح المقاصد والمسالك بشرح ألفية ابن مالك، أبو تحمد بدر الدين

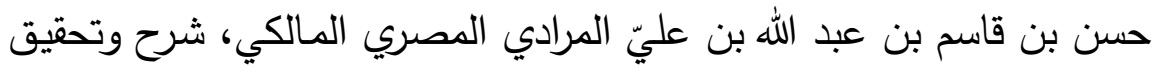

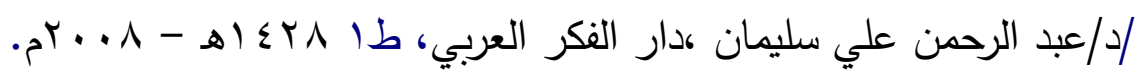

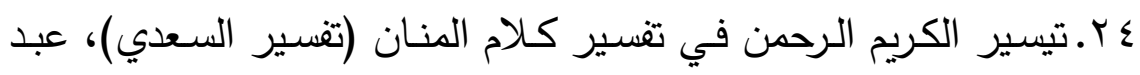

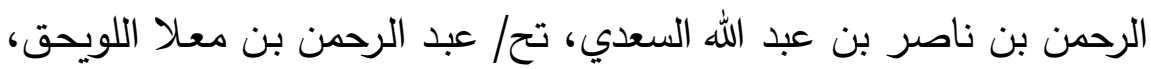

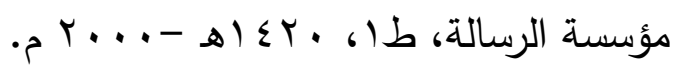

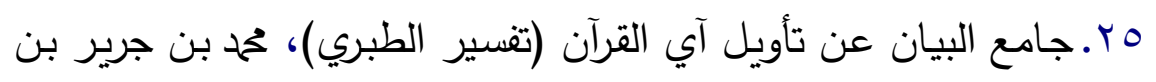

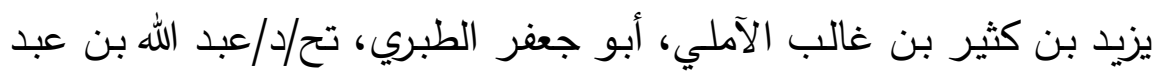

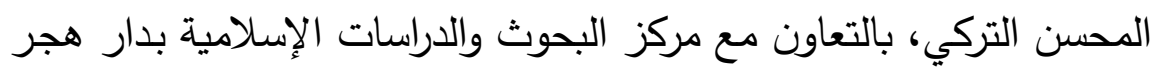

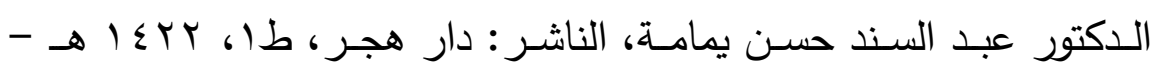
r...

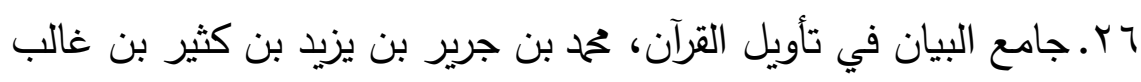

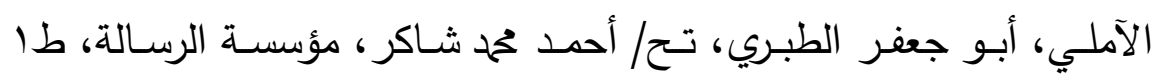

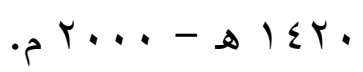
VV V. الجامع لأحكام القرآن ( تفسير القرطبي)، أبو عبد الله محمد بن أحمد بن

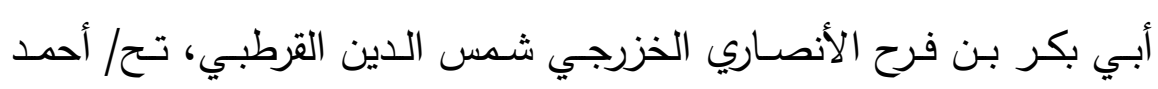

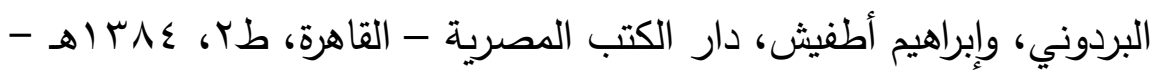

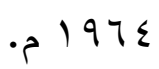
^ץ. الجدول في إعراب القرآن الكريم، محمود بن عبد الرحيم صافي، دار

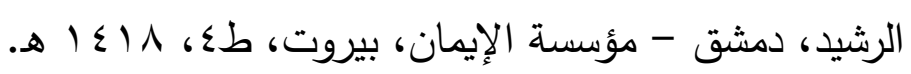

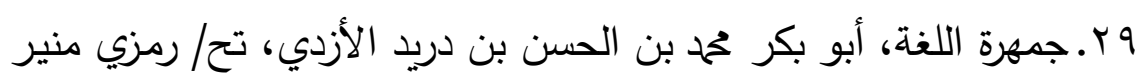

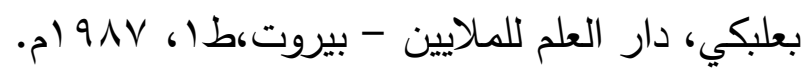


• ץ. الجواهر الحسـان في تفسير القرآن، أبو زيد عبد الرحمن بن محمد بن

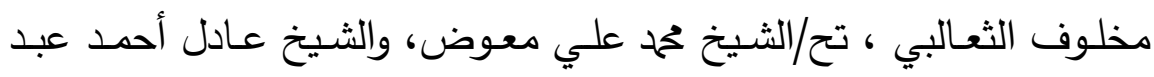

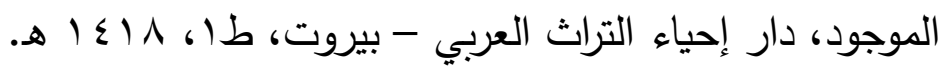

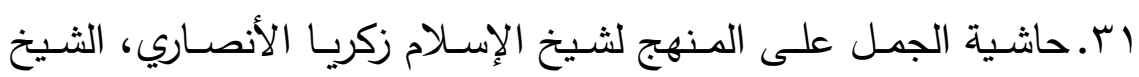

$$
\text { سليمان الجمل، دار الفكر - بيروت. }
$$

r..خـواطر إيمانيـة، محمد متولي الثـعراوي، الناشـر : مطـابع أخبار اليـوم، . $99 \mathrm{VD}$

سז.الدر المنثور في التفسير بالمأثور، عبد الرحمن بن أبي بكر، جـلال الدين السيوطي، دار الفكر - بيروت.

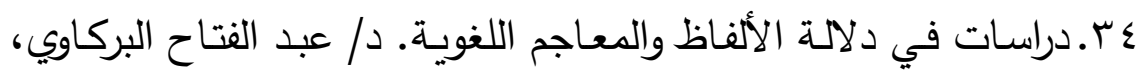

$$
\text { طr، }
$$

هr.دراسات في فقه اللغة، د. صبحي إبراهيم الصالح، دار العلم للملايين،

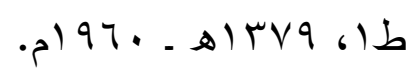

بس.دستور العلماء أو جامع العلوم في اصطلاحات الفنون، القاضي عبد رب النبي بن عبد رب الرسول الأحمد نكري، تحقيق وعرب عباراته الفارسية:

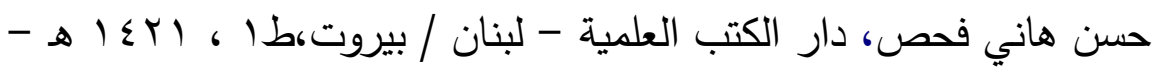
r.... rV. دلالة السياق بين التراث وعلم اللغة الحديث ( دراسة تحليلية للوظائف

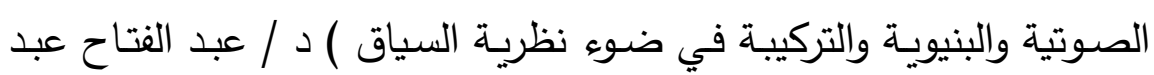
العليم البركاوى.

^ז. ديـوان زهير بـن أبي سلمى، اعتنى بـه وشـرحه/ حمدو طمـاس، دار

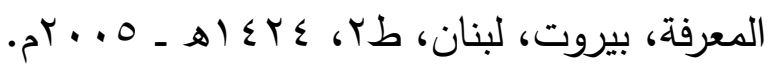

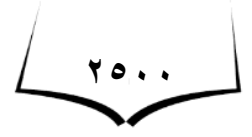




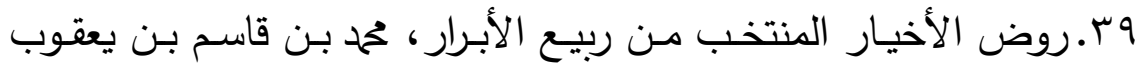

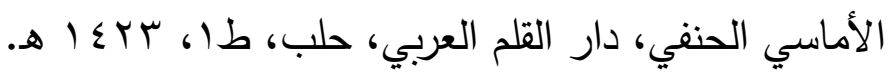
• ـ. الزاهر في غريب ألفاظ الثـافعي، محمد بـن أحمد بـن الأزهر الأزهري

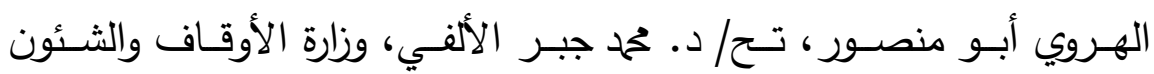

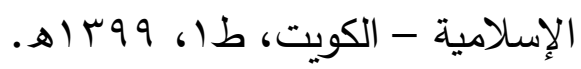

| أ.الزاهر في معانى كلمات الناس، أبو بكر قحمد بن القاسم الأنباري، تح/

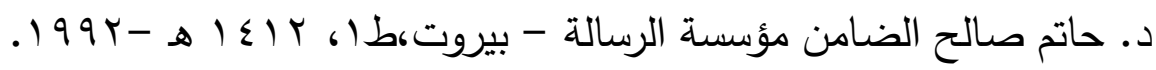

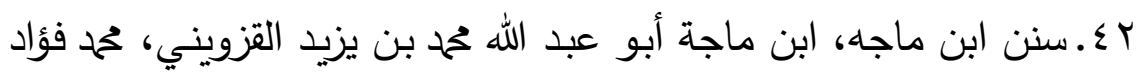
عبد الباقي، دار إحياء الكتب العربية ، فيصل عيسى البابي الحلبي.

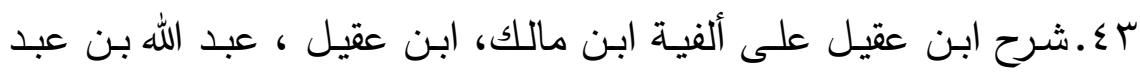
الرحمن العقيلي الهمداني، تح/ تحمد محيي الدين عبد الحميد، دار التراث -

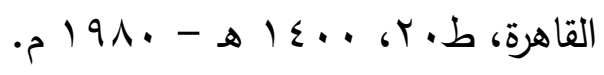

§. شرح سنن أبي داود، أبو محمد محمود بن أحمد بن موسى بن أحمد بن حسين الغيتابى الحنفى بدر الدين العينى، تح/ أبو المنذر خالد بن إبراهيم

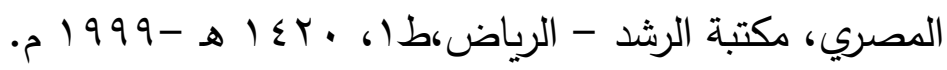
0ـ.شرح نهج البلاغة، عبد الحميد بن هبة الله بن محمد بن الحسين بن أبي الحديد، تح/ ححم أبو الفضل إبراهيم، دار إحياء الكتب العربية عيسى البابي

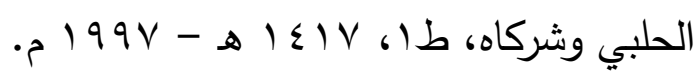
7ـــ العقد الفربد، أبو عمر ، شهاب الدين أحمد بـن محمد بن عبد ربـه ابن

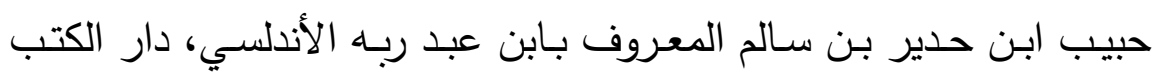

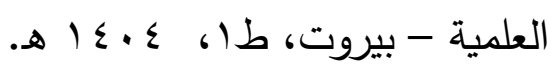

V V Vـ علم الدلالة، د/أحمد مختار عمر، عاله الكتب، القاهرة. 


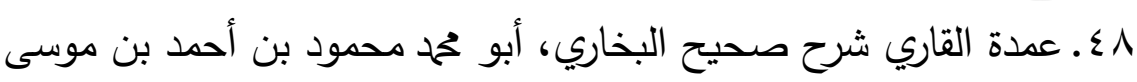
بن أحمد بن حسين الغيتابى الحنفى بدر الدين العينى ، دار إحياء التراث

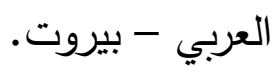

9 ـ غرائب التفسير وعجائب التأويل، محمود بن حمزة بن نصر ، أبو القاسم

$$
\text { برهان الدين الكرماني، دار القبلة للثقافة الإسلامية - جدة. }
$$

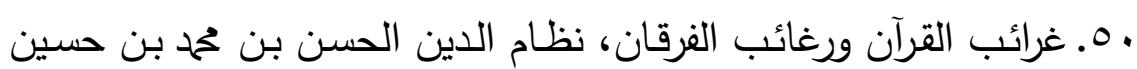

القمي النيسابوري، تح/ الثيخ زكريا عميرات، الناشر/ دار الكتب العلمية -

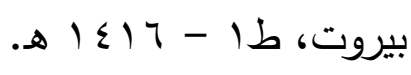

10.فتح القدير، محمد بن علي بن محمد بن عبد الله الشوكاني اليمني، دار ابن

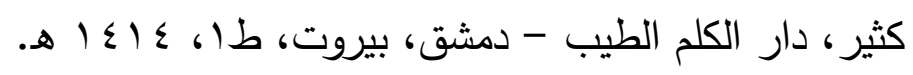

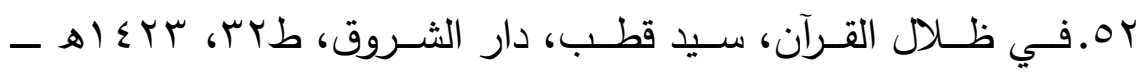

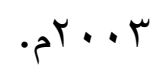

ror.فيض القدير شرح الجامع الصغير ، زين الدين قحم المدعو بعبد الرؤوف أم

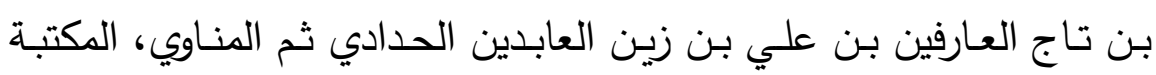

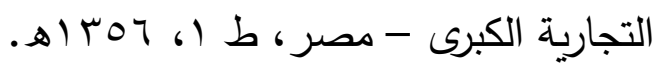

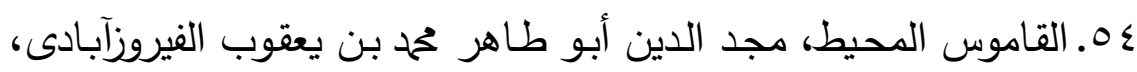
تــح/ مكتــب تحقيـق التـراث فـي مؤسســة الرســالة، بإشـراف: محمد نعـيم

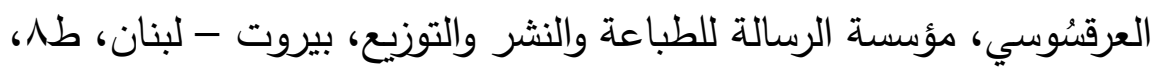

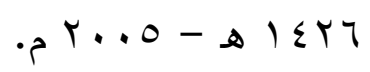

هـ الكثاف عن حقائق غوامض التنزيل، أبو القاسم محمود بن عمرو بن

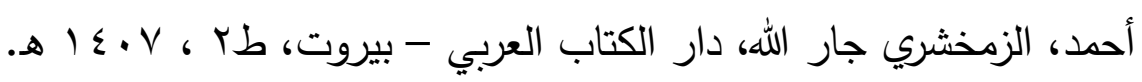


الإهـ الكثف والبيان عن تفسير القرآن، أحمد بن محمد بن إبراهيم الثعلبي، تح/

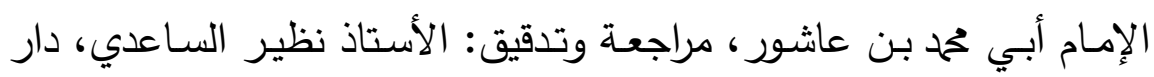

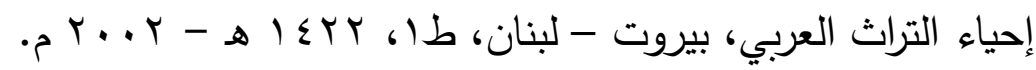

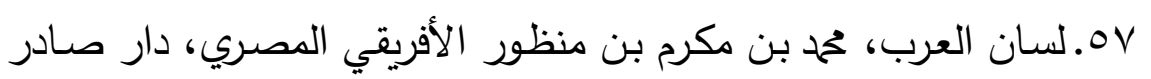

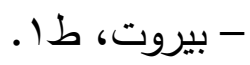

101. اللباب في علوم الكتاب، أبو حفص سراج الدين عمر بن علي بن

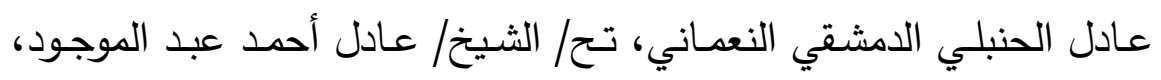

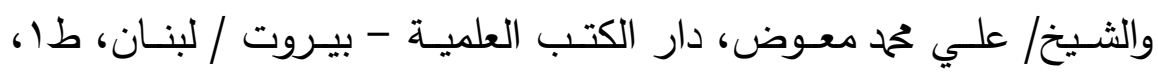
. $1991-1919$ هو. اللغة، جوزيف فندريس، تعريب/ عبد الحميد الدواخلي، محم القصاص، مكتبة الأنجلو المصرية، ط. ب. 90 ام.

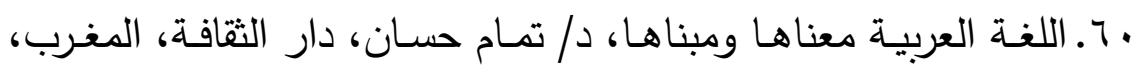
$.0199 \varepsilon$ ا7. آحاسـن التأويـل، محمد جمـال الدين بـن محم سـعيد بـن قاسم الحـلاق

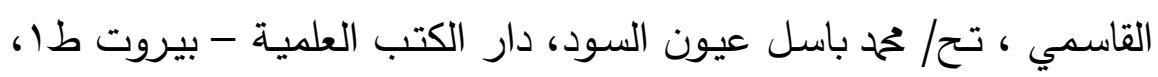
(1)

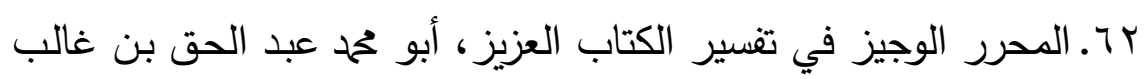

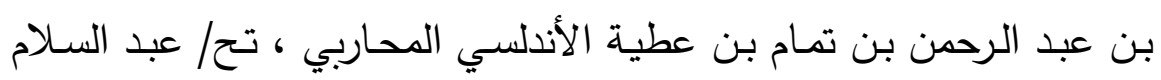

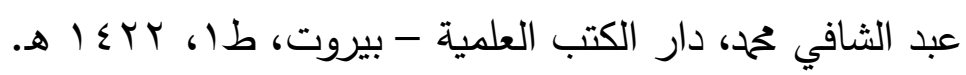

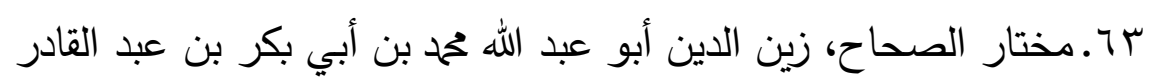

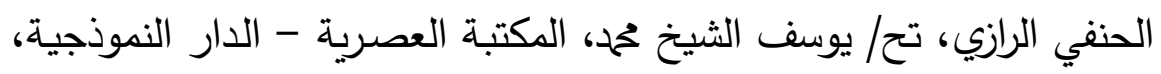

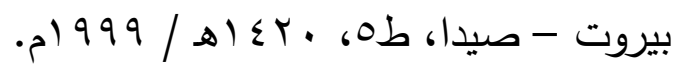




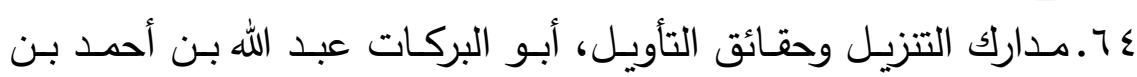
محمود حافظ الدين النسفي، تح/ يوسف علي بديوي، محيي الدين ديب مستو، دار الكلم الطيب، بيروت، طا، 99 اع 1 هـ - 1991 م.

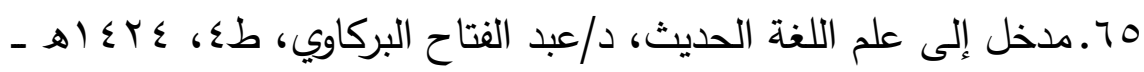

$$
\text { . . . E }
$$

77. المخصص، أبو الحسن علي بن إسماعيل بن سيده المرسي، تح/ خليل

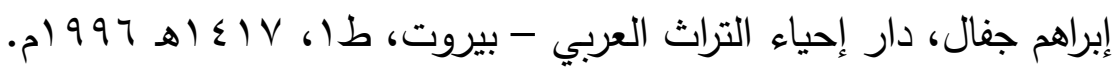

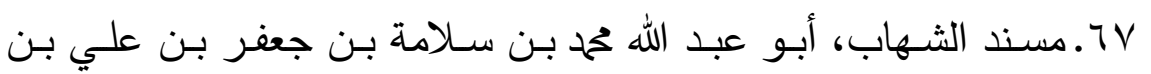
حكمـون القضـاعي المصـري تـح/ حمدي بـن عبد المجيد السـلفي، مؤسســة

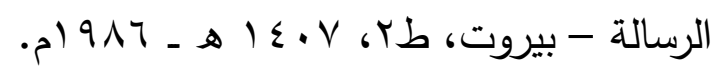

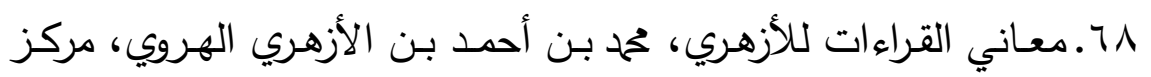
البحوث في كلية الآداب - جامعة الملك سعود، المملكة العربية السعودية،

$$
\text { ط إن }
$$

9. 9 ـمعاني القرآن وإعرابه، إبراهيم بن السري بن سهل، أبو إسحاق الزجاج،

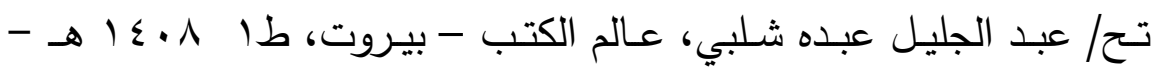
• $19 \wedge 1$ • V. المعجم الاشتقاقي المؤصل لألفاظ القرآن الكريم، د/ ححمد حسن حسن

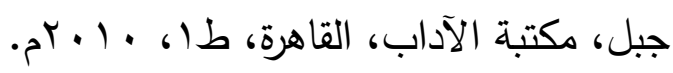

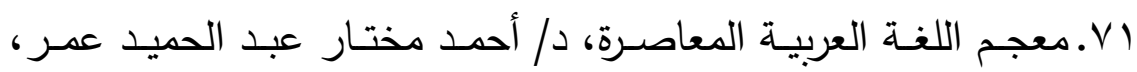

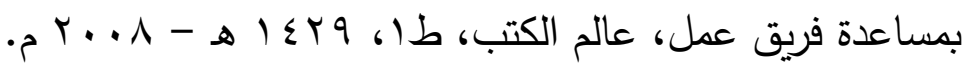

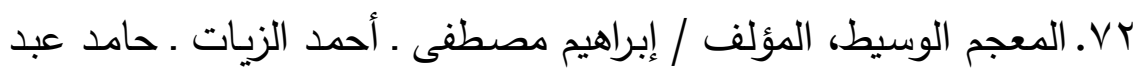
القادر ـ محمد النجار ، تح/ مجمع اللغة العربية، بالقاهرة، دار الدعوة. 


\section{مجلةققطاع كليات اللفة العريية والشعب المناظرة لها العذد [rا]}

rا. معجم مقاييس اللغة، أحمد بن فارس بن زكرياء القزويني الرازي، تح/

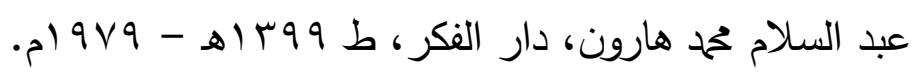

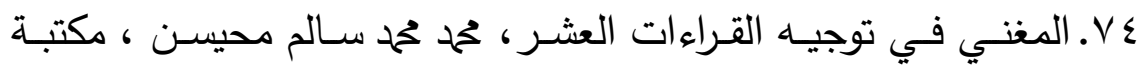

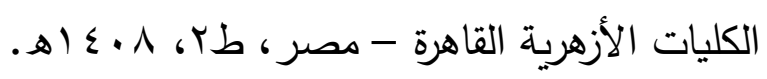

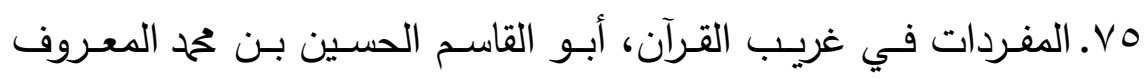

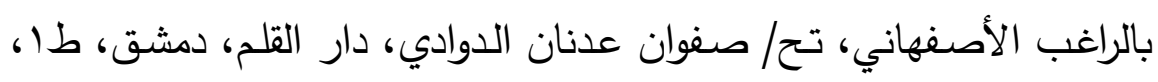
.ه

VT. الموجز في قواعد اللغة العربية، سعيد بن ححم بن أحمد الأفغاني، دار

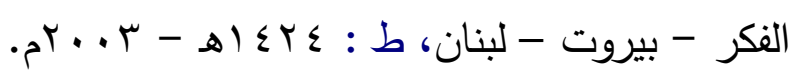

VV نزهة الأعين النواظر في علم الوجوه والنظائر ، جمال الدين أبو الفرج

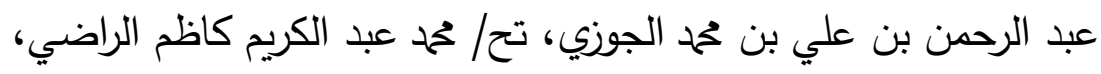

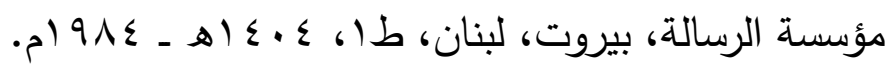

^v. النكت والعيون، أبو الحسن علي بن ححم بن حبيب الماوردي البصري،

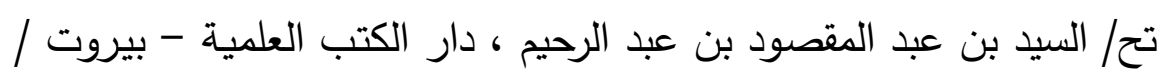
لبنان.

9. الهادي شرح طيبة النشر في القراءات العشر، خحمد محمد سالم محيسن،

$$
\text { دار الجيل - بيروت. }
$$

• ـ. همع الهوامع في شرح جمع الجوامع، عبد الرحمن بن أبي بكر ، جلال الدين السيوطي ، تح/ عبد الحميد هنداوي، المكتبة التوفيقية - مصر .

^^.الوجوه والنظائر لألفاظ كتاب الله العزيز ومعانيها، أبو عبد الله الحسين بن محم الدامغاني، دراسة وتحقيق/ فاطمة يوسف الخيمي، مكتبة الفارابي،

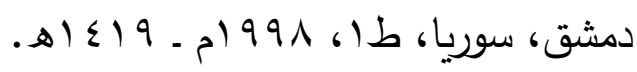

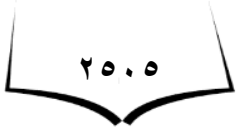


الإحيـاء، مجلـة فصـلية تصدرها الرابطـة المحمديـة للعلمـاء، العـد OY،

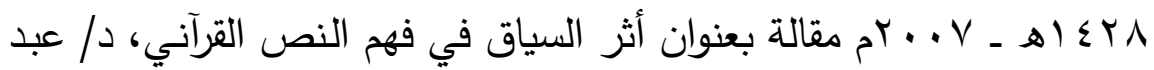

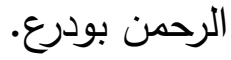
مجلـة جامعـة الملك سـودد، مع ب، العلوم التربويـة والدراسـات الإسـلامية

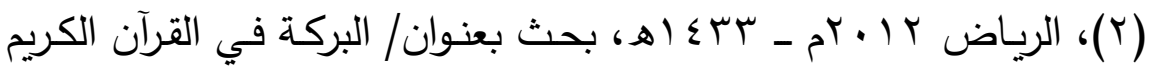
دراسة موضوعية، د/ وفاء بنت عبد الله الزعاقي، المواقع الإلكترونية أصول النظرية السياقية الحديثة عند علماء العربية ، د/ حخد سالم صـالح http://www.hamassa.com/wp- - بحث منشور على الرابط التالي content/uploads/2016/05 أقسام السياق في الدلالة، د/سامح عبد السلام تحد، بحث منشور على

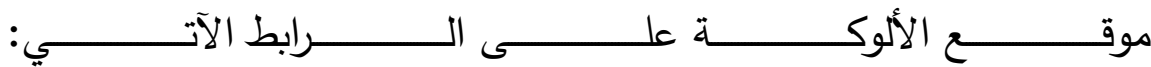
/http://www.alukah.net/literature_language/0/69299 